\title{
Subsurface stratigraphy and depositional patterns of the Lower Mississippian Weir zone of Doddridge County, West Virginia, with emphasis on reservoir potential
}

John Hamilton Tellers

West Virginia University

Follow this and additional works at: https://researchrepository.wvu.edu/etd

\section{Recommended Citation}

Tellers, John Hamilton, "Subsurface stratigraphy and depositional patterns of the Lower Mississippian Weir zone of Doddridge County, West Virginia, with emphasis on reservoir potential" (2008). Graduate Theses, Dissertations, and Problem Reports. 2643.

https://researchrepository.wvu.edu/etd/2643

This Thesis is protected by copyright and/or related rights. It has been brought to you by the The Research Repository @ WVU with permission from the rights-holder(s). You are free to use this Thesis in any way that is permitted by the copyright and related rights legislation that applies to your use. For other uses you must obtain permission from the rights-holder(s) directly, unless additional rights are indicated by a Creative Commons license in the record and/ or on the work itself. This Thesis has been accepted for inclusion in WVU Graduate Theses, Dissertations, and Problem Reports collection by an authorized administrator of The Research Repository @ WVU. For more information, please contact researchrepository@mail.wvu.edu. 
Subsurface Stratigraphy and Depositional Patterns of the Lower Mississippian Weir Zone of Doddridge County, West Virginia, with emphasis on Reservoir Potential

John Hamilton Tellers

Thesis submitted to the Eberly College of Arts and Sciences

at West Virginia University in partial fulfillment of the requirements

for the degree of

Master of Science

in

Geology

Richard Smosna, Ph.D., Chair

Thomas Kammer, Ph.D.

William Carpenter, M.S.

Craig Edmonds, M.S.

Department of Geology and Geography

Morgantown, West Virginia

2008

Keywords: Weir, Early Mississippian, Appalachian Basin, Doddridge County, West Virginia, Tight gas 


\begin{abstract}
Subsurface Stratigraphy and Depositional Patterns of the Lower Mississippian Weir Zone of Doddridge County, West Virginia, with emphasis on Reservoir Potential

John Hamilton Tellers

The Weir zone of Doddridge County, West Virginia, is considered to be an unconventional reservoir due to its low permeability. Analysis of this zone was performed using well log data from 300 wells, a full-bore core of the Weir, and petrographic thin sections. Three lithologies occur within the Weir: coarse siltstone, fine siltstone, and claystone. Bedforms were identified using a combination of FMI, thin section, and core analysis. The Weir is interpreted to have been deposited on an outer shelf under the influence of shoaling internal waves. Log analysis provided data showing the unit to have a mineral composition of quartz, illite, and potassium feldspar.

The Lower Weir has the potential to be a productive secondary target for natural gas over a large part of the study area in Doddridge County. These areas have been selected because the combination of a high volume of secondary moldic porosity, total thickness of the Weir siltstone, and an increased likelihood of fracture porosity aiding in permeability. Zones identified within the Weir for production were selected on the basis of low water saturation, relatively high permeability, and relatively high porosity.
\end{abstract}




\section{ACKNOWLEDGMENTS}

The final draft of this thesis could not have come to be without the monumental efforts of some notable people. First and foremost, Dr. Richard Smosna, anyone who has had the pleasure of working with him knows the knowledge and guidance he brings to any project. Special thanks also go out to Dr. Thomas Kammer, Mr. William Carpenter, and Mr. Craig Edmonds. Without having their input this work would be substandard.

Thanks to Dominion Exploration and Production for providing me with the data required to complete this thesis specifically, Melissa Sager and Anthony Johnson for the help and advice they provided me with GeoGraphix. Also, thanks to Doug Reif for his tireless effort and input.

Thanks to Lee Avary and the West Virginia Geological and Economic Survey for their advice and the use of their well logs. Recognition should also be given to the faculty and staff of WVU not specifically mentioned above, for their knowledge and support has now provided me with two degrees.

Lastly, special thanks to my family and friends, including my mother and father who have supported me in every way possible and my two brothers who knowingly, or unknowingly, provided me with life lessons that have encouraged me to perform at my best. To my fiancée, Elizabeth, thank you for seeing me through this journey. As it comes to an end, ours will continue onward. 
TABLE OF CONTENTS PAGE

ACKNOWLEDGEMENTS................................................ iii

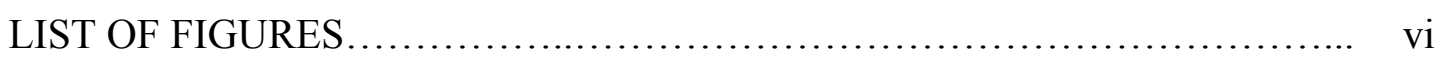

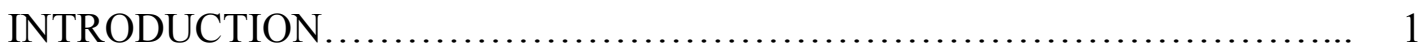

Purpose............................................... 1

Study Area and Data Sources............................ 2

GEOLOGICAL BACKGROUND......................................... 6

The Lower Weir Beds..................................... 11

The Middle Weir Beds......................................... 14

The Upper Weir Beds.................................... 16

METHODS .............................................................. 18

Well Logs.......................................... 18

Measured Well - Log Parameters......................... 22

Formation MicroImager Analysis........................... 25

Core Porosity and Permeability.......................... 27

Petrographic Thin Section and Core Analysis................. 28

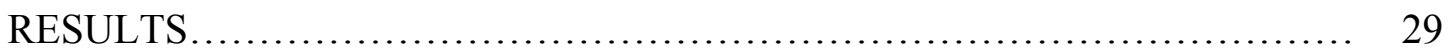

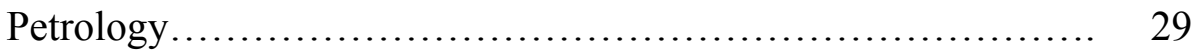

Thickness............................................... 51

Depositional Environment............................. 55

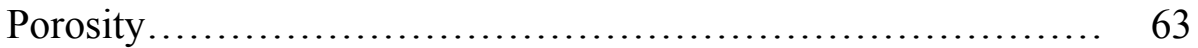

Structure........................................... 73

Potential Reserves........................................... 78 
CONCLUSIONS......................................................... 81

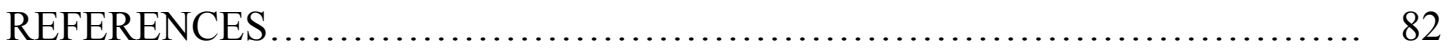




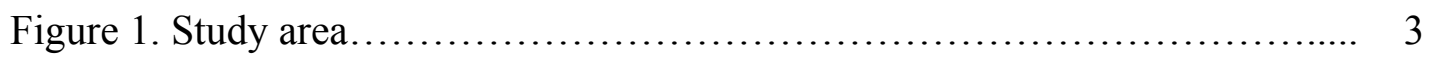

Figure 2. Study area with lines of cross section............................. 4

Figure 3. Chronostratigraphic chart............................................ 7

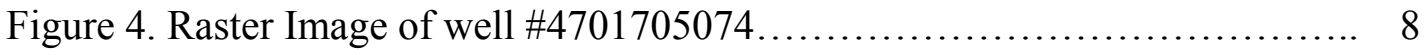

Figure 5. Cross section of the Price Formation along eastern West Virginia....... 9

Figure 6. Isopach of the Lower Weir beds from Zou......................... 12

Figure 7. Isopach of the Lower Weir beds from Boswell and Jewell.............. 13

Figure 8. Isopach of the Middle Weir beds..................................... 15

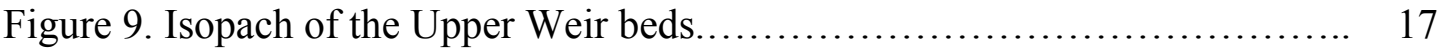

Figure 10. Gamma-ray curve of the Lower Weir within well \#4701705448_....... 19

Figure 11. Zone Manager application.............................................. 21

Figure 12. Neutron porosity, PE, and bulk density curve for well \#4701705448... 23

Figure 13. Top of the Lower Weir beds represented on FMI log................. 30

Figure 14. Grain size data from thin sections............................... 31

Figure 15. Mean grain size against depth.................................. 32

Figure 16. Photomicropgraph of the Lower Weir at 2178.25 feet.................. 33

Figure 17a-d. Rhomaa - Umaa crossplots................................. $34-36$

Figure 18. Typical coarse grained siltstone section.......................... 37

Figure 19. Typical fine grained siltstone section............................. 38

Figure 20. Typical claystone section..................................... 39

Figure 21. Vertical change from coarse siltstone to claystone.................... 40 
vii

Figure 22. Depth distribution of three lithofacies identified from the FMI log..... 41

Figure 23. Summary table of the Lower Weir lithofacies................... 42

Figure 24. Claystone partings seen at 2212 feet.......................... 43

Figure 25. Fine siltstone bed that has been altered through bioturbation.......... 44

Figure 26. Shell fragments within the core $\ldots \ldots \ldots \ldots \ldots \ldots \ldots \ldots \ldots \ldots \ldots \ldots . . \ldots \ldots$

Figure 27. Crinoid stem........................................... 45

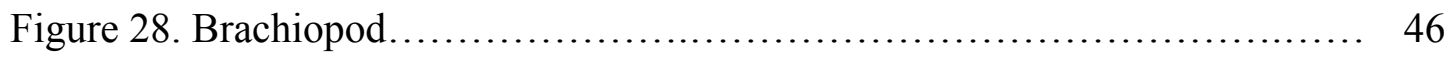

Figure 29. Single large plant debris specimen........................... 46

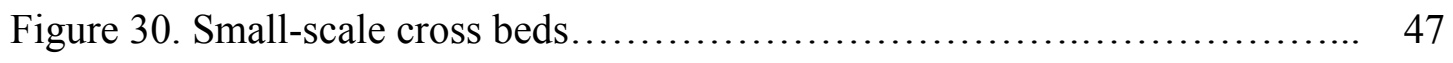

Figure 31. FMI response to plant layers $\ldots \ldots \ldots \ldots \ldots \ldots \ldots \ldots \ldots \ldots \ldots \ldots \ldots, \quad 48$

Figure 32. Vertical burrows.......................................... 49

Figure 33. PETRA log plot for well \#4701705448...................... 50

Figure 34. Log response for the Lower Weir within well \#4701701864_......... 51

Figure 35. Isopach map of the Lower Weir beds........................ 52

Figure 36. Siltstone percent map of the Lower Weir........................ 54

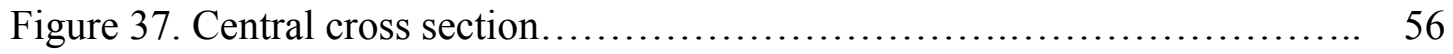

Figure 38. Southern cross section.................................. 57

Figure 39. Cross beds seen within the FMI log......................... 58

Figure 40. Rose Diagram of the Lower Weir cross beds.................... 59

Figure 41. Pictorial representation of internal waves...................... 61

Figure 42. Paleogeography map of the Lower Weir....................... 62

Figure 43. Net-pay map of siltstone with $6 \%$ or more porosity................ 64

Figure 44. Net-pay map of siltstone with $8 \%$ or more porosity ......................... 65 
viii

Figure 45. Photomicrograph of the pores within the Lower Weir 2178.25 feet..... 66

Figure 46. Pore size data................................................ 67

Figure 47. Photomicrograph of the Lower Weir at 2209.3.................. 68

Figure 48. Log plot of the cored well including zones of interest.............. 69

Figure 49. Core porosity and Permeability............................. 70

Figure 50. Pickett Plot for the Lower Weir beds in well \#4701705448............ 71

Figure 51. Pickett Plot for the specific zone from depths 2225 to $2250 \ldots \ldots \ldots \ldots . . .72$

Figure 52. Structure map of the top of the Big Lime....................... 75

Figure 53. Structure map of the top of the Lower Weir beds................... 76

Figure 54. Rose Diagram of dip-meter readings......................... 77

Figure 55. Average and cumulative production from well $\# 4701701903 \ldots \ldots \ldots \ldots . \quad 79$

Figure 56. Time map over laying percent siltstone map.................... 80 


\section{INTRODUCTION}

\section{Purpose}

Sandstones of the Mississippian Weir zone are important oil and gas reservoirs in eastern Kentucky, southwestern Virginia, and throughout West Virginia. Initial open flow rates range between 2 and 30,000 $\mathrm{Mcfg} / \mathrm{d}$ with an average of 1,000 Mcfg/d, and estimates for the Weir in West Virginia suggest that an additional 131.4 billion cubic feet of gas is recoverable (Matchen and Vargo, 1996). Despite these impressive numbers, production from the unit has been sporadic due to rapid declines after fracture stimulation. The Weir zone, too, has frequently been passed over as a target formation because of its low permeability. The permeability of the Weir zone meets the National Energy Technology Laboratory (2007) definition of a tight play: less than 0.1 millidarcy. As exploration and production technology continues to advance, identifying optimum zones within a tight gas formation becomes imperative to enhance production.

This study was undertaken to better understand the depositional environment of the Weir zone in Doddridge County, West Virginia. Previous interpretations were made based solely on gross thickness patterns of the sandstone, but the present study entails a more detailed examination of all available subsurface data. A full-bore core through the Weir zone and logs from 300 wells provide the data base. A second purpose of this study was to examine this zone with particular interest to natural-gas production from an unconventional or tight gas reservoir.

This study will aid in the identification of any additional reserves that have not been previously discovered. Typical shallow wells in this area extend to the base of the Mississippian Big Injun, and exploration of the deeper Weir zone would require just an 
additional few hundred feet of drilling. Given the minimal amount of extra drilling required to penetrate the Weir zone, the potential for profit easily outweighs the minor cost. The current (2007) cost of drilling a well to the Big Injun is approximately $\$ 250,000$; drilling the extra 200 feet to the Weir zone would require an estimated additional $\$ 15,000$. This expense could easily be recovered by production from the Weir zone of just 30-40 Mcfg/d per well.

By examining the Weir zone in terms of areal extent, depth, thickness, depositional environment, lithologic heterogeneity, and porosity distribution, the chances of successful drilling within Doddridge County will be greatly enhanced. This thesis identifies optimal locations for future drilling and reworking of existing wells where the Weir zone was drilled but not completed.

\section{Study Area and Data Sources}

The study area consists of portions of Oxford, West Union, Smithburg, and New Milton quadrangles in Doddridge County, West Virginia (Figure 1). This area covers the most northern extent of the Lower Weir beds in the subsurface of West Virginia (Zou, 1993). My environmental interpretations are based primarily on a 150-foot long, fullbore core (4" diameter) of the Weir zone and portions of the surrounding units. The core (API \#4701705448) was drilled during the fall of 2007 in West Union quadrangle by Dominion Exploration and Production Inc. (Figure 2). CoreLab of Houston, TX, slabbed the core and prepared 15 thin sections extending over the entire core. The primary data set for this study consists of 300 well logs (Figure 2), including Gamma- Ray, Neutron- 
Porosity, Density-Caliper, Compensated-Density, Shallow-

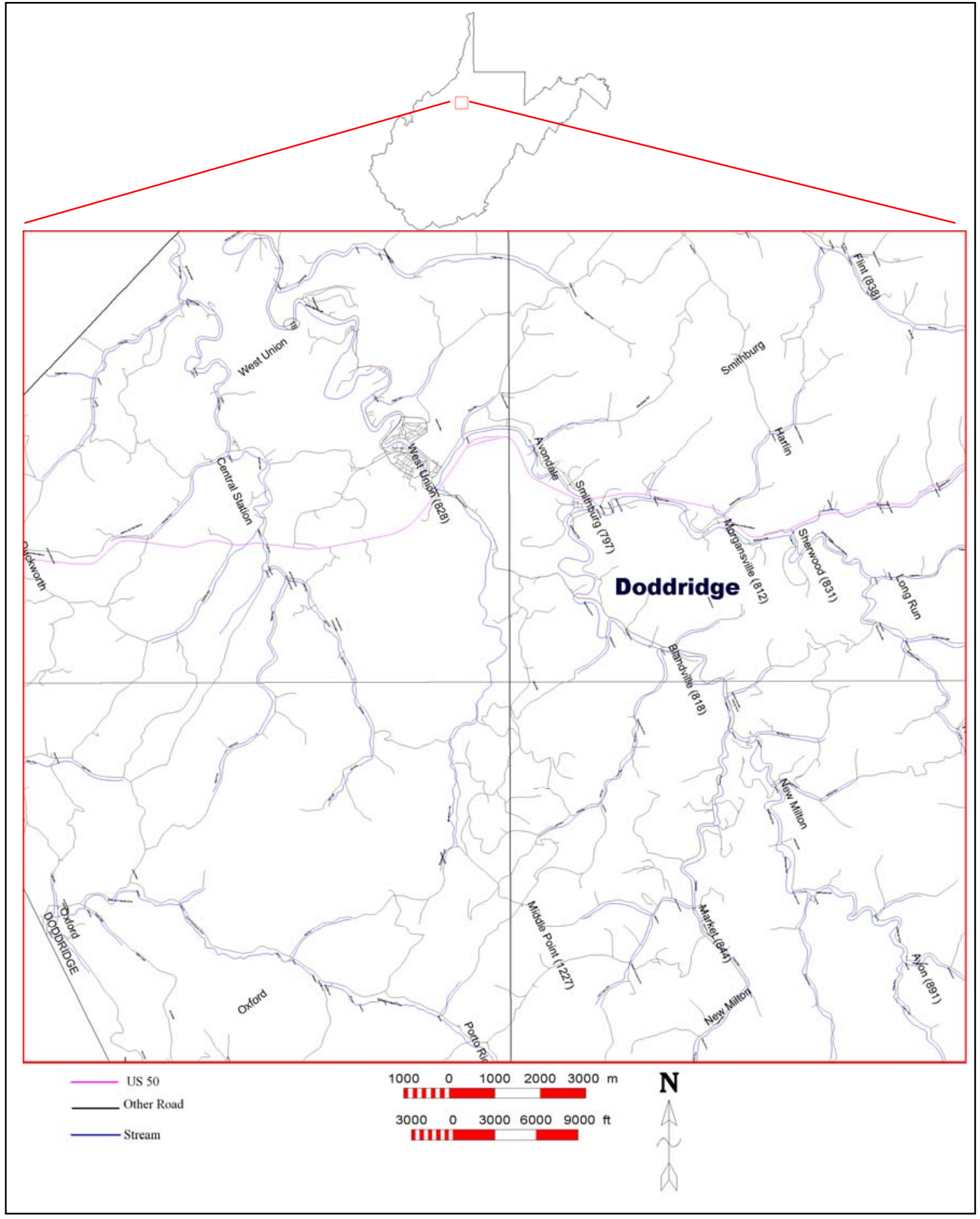

Figure 1: Map showing the location of the study area. 


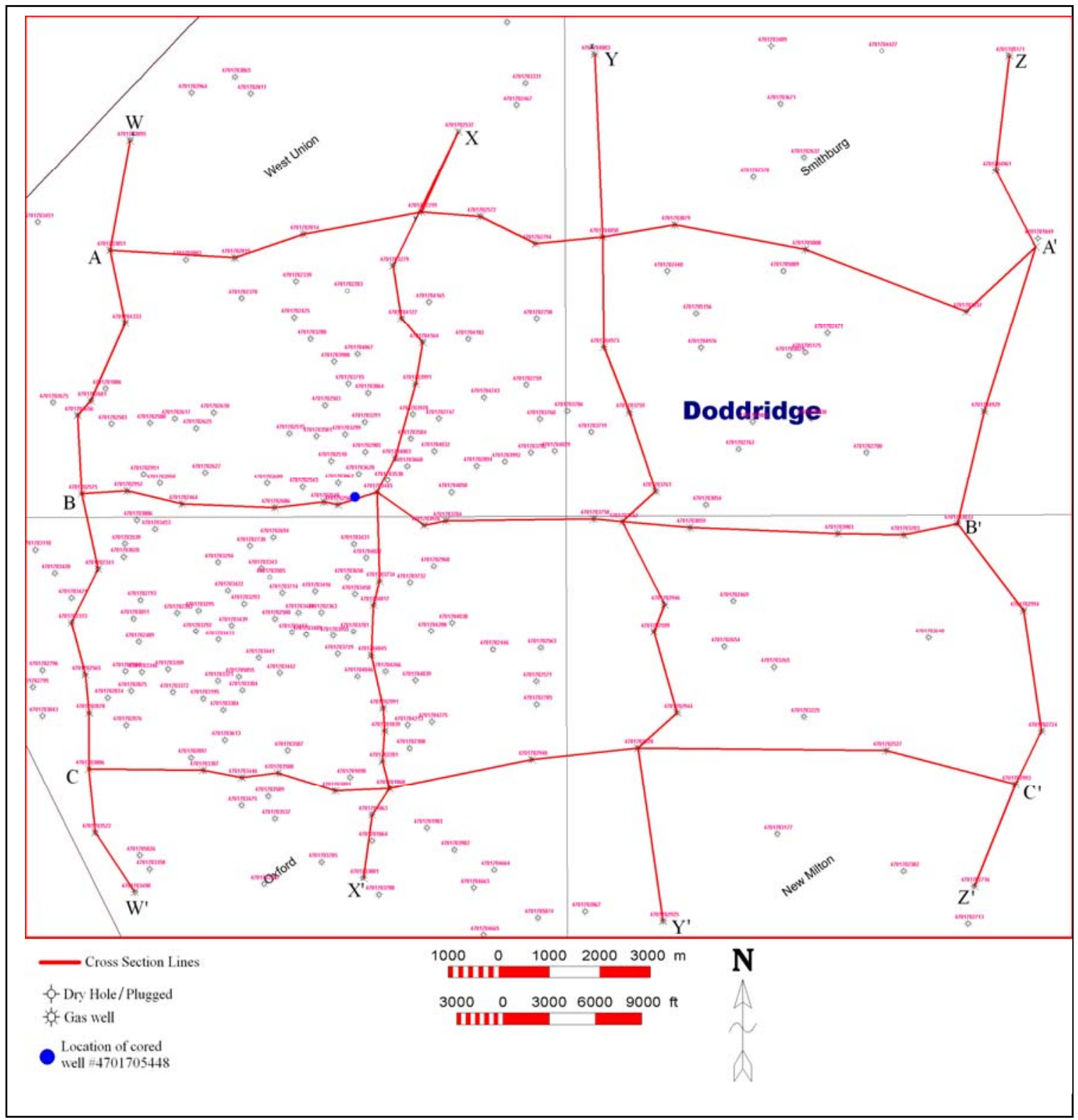

Figure 2: Map showing cross-sections across the study area, location of logged wells, and the cored well. 
Induction, Medium-Induction, High-Induction, Audio, and Temperature. Not all well logs contained data from all of these tools; however, they were used when available. These data were taken from the West Virginia Geologic and Economic Survey in Morgantown, West Virginia, and Dominion Exploration and Production Inc. in Jane Lew, West Virginia. Well logs were analyzed primarily using GeoGraphix software which provided subsurface maps showing the structure, thickness, and net pay of the Weir zone. Seven cross sections, also modeled in GeoGraphix, show how thickness, porosity, and structure vary across the study area (Figure 2). Other software used in this study includes PETRA subsurface modeling software and the Excel add-in program PfEFFER which provide a detailed analysis of the well logs. 


\section{GEOLOGICAL BACKGROUND}

The Price Formation of West Virginia encompasses the stratigraphic units occurring between the Upper Devonian Hampshire Formation and the Lower Mississippian Maccrady Formation in southern West Virginia or the Upper Mississippian Greenbrier Limestone Group in the central and northern part of the state (Bjerstedt, 1986). Bjerstedt (1986) and Bjerstedt and Kammer (1988) showed that the Price Formation contains a range of deltaic deposits from marine to marginal marine to terrestrial that accumulated during four transgressions and regressions of sea level. The Price correlates to the Bedford Shale through the lower Borden Formation of Kentucky, Bedford Shale through the Cuyahoga Formation of Ohio, and the Oswayo through Shenango Formation of Pennsylvania (Matchen and Vargo, 1996) (Figure 3).

The Weir zone falls within the middle Price Formation and includes three separate sandstone beds termed the Upper, Middle, and Lower. It is Kinderhookian in age and situated between the Sunbury Shale below and the Big Injun or Squaw sandstone above. In the subsurface the Weir zone is rarely identified relative to the overlying stratigraphic units for two reasons. First, the overlying pre-Greenbrier unconformity has removed a varying thickness of Lower Mississippian strata in West Virginia (Boswell, 1988; Boswell and Jewell, 1988). Second, the Upper Weir beds may be confused with the Squaw sandstone, however, within the study area this is not the case. The Squaw is a thin sandstone above the Weir zone and associated with the overlying Big Injun. It is separated from the Weir zone by a thin unnamed shale (Matchen and Vargo, 1996), but this shale is similar to those that occur among the Weir beds and can lead to confusion 
(Zou, 1993). A better marker to identify the Weir zone is the underlying organic-rich Sunbury Shale that can be easily recognized and correlated across West Virginia. On well logs the Sunbury exhibits a high response on a gamma-ray curve (Zou, 1993). However, the well-log data show that the typically high gamma-ray reading of the Sunbury Shale is not pronounced in Doddridge County (Figure 4). This low count reflects a lateral facies change from the Sunbury Shale to the Riddlesburg Shale in northern West Virginia (Bjerstedt and Kammer, 1988) (Figure 5).

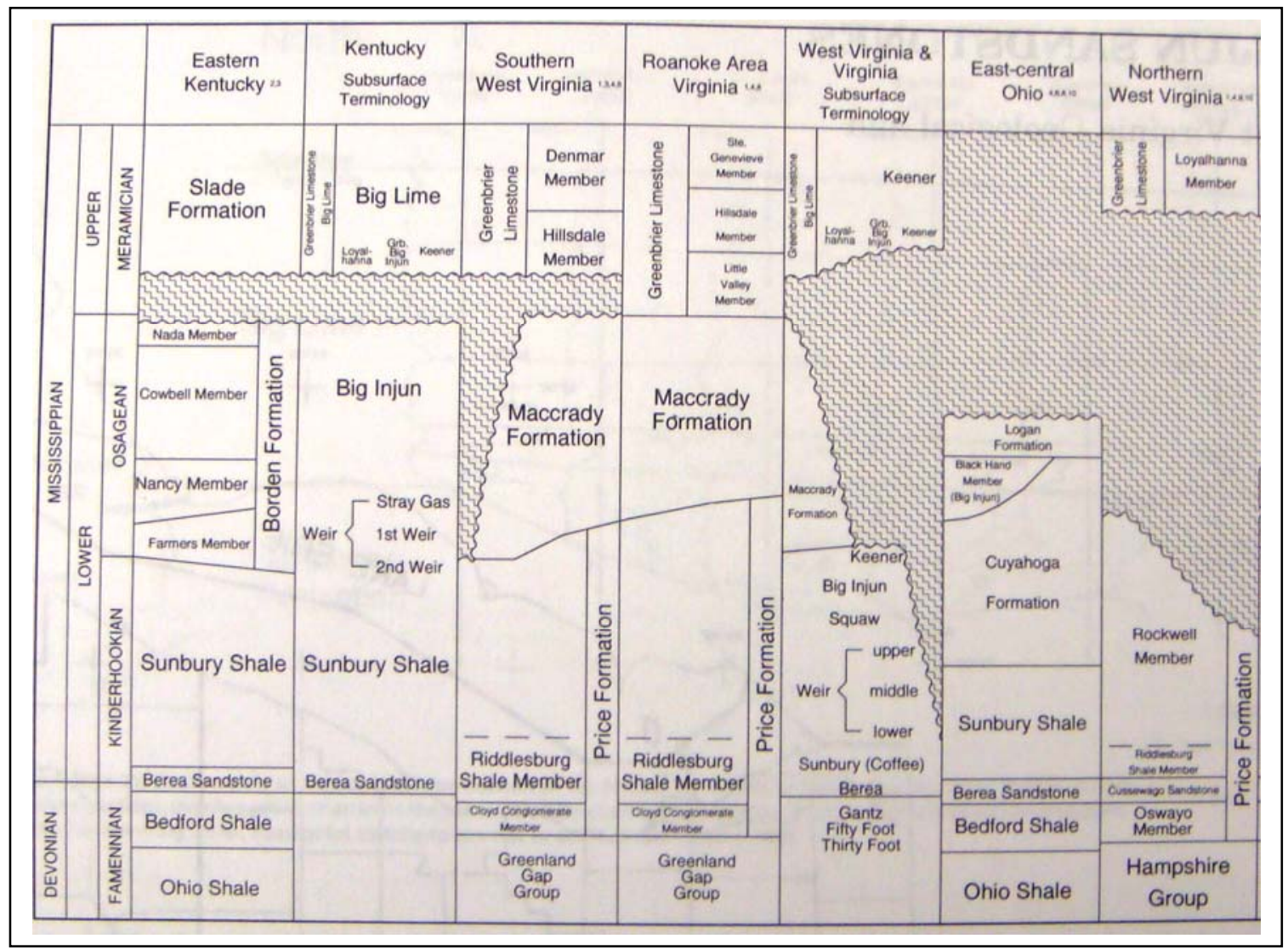

Figure 3: Chronostratigraphic chart for the Upper Devonian to Upper Mississippian showing the Price Formation and its relation to surrounding formations (modified from Matchen and Vargo, 1996). 


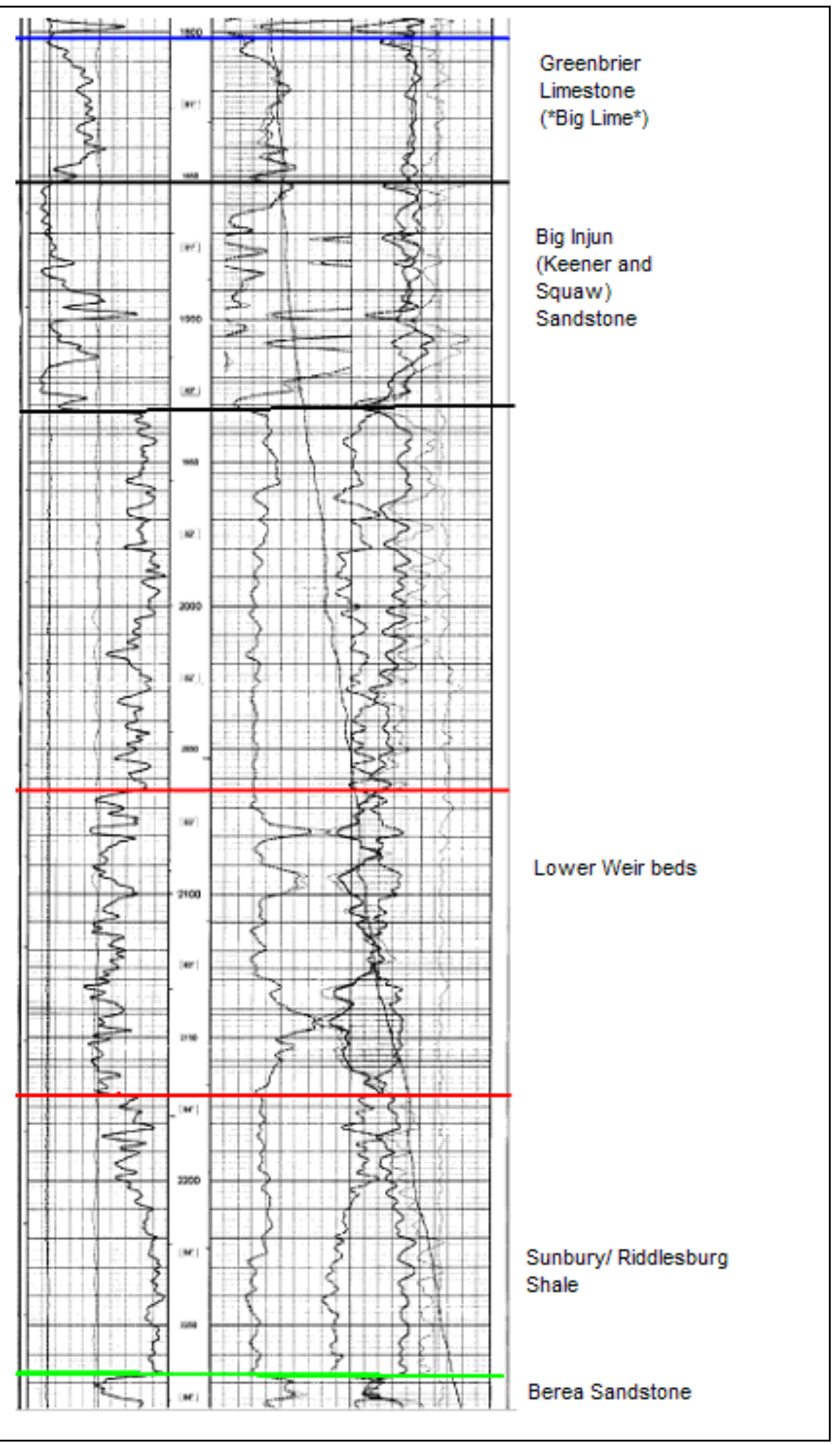

Figure 4: Gamma-ray log (left track, solid dark line) from well \#4701705074 showing the Lower Weir beds and surrounding stratigraphic units in Doddridge County. Tracks on the right include induction, temperature, neutron-porosity, and compensated-density. 


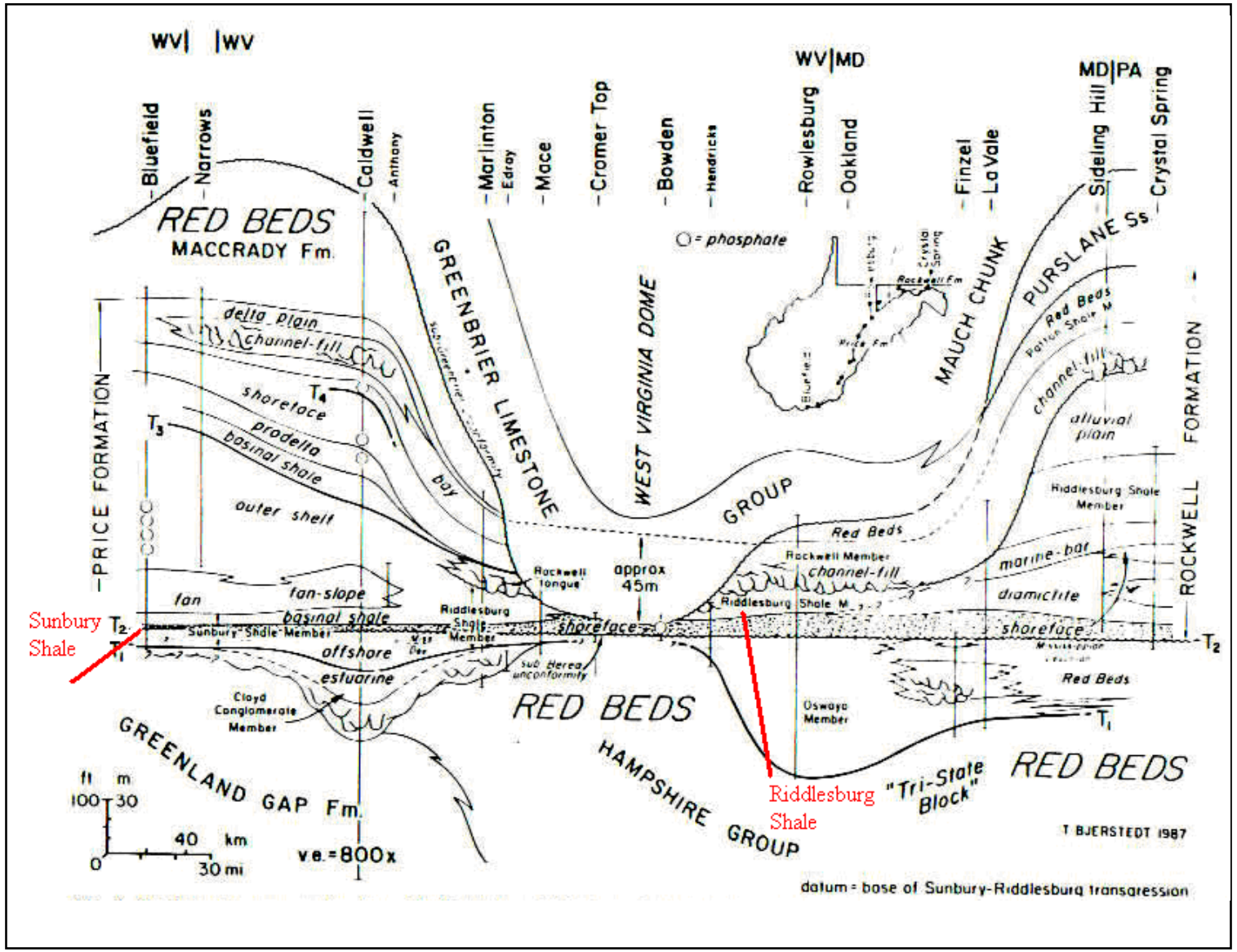

Figure 5: Cross-section based on outcrops from Bluefield, WV, to Crystal Spring, PA, shows the relation of the Price and Rockwell Formations to the Greenbrier Group and its basal unconformity, datum is the base of the Mississippian (modified from Bjerstedt and Kammer, 1988).

The three beds of the Weir zone are identified by drillers based on their position above the Sunbury Shale (Matchen and Kammer, 1994). Sandstones within 100 feet of the Sunbury Shale comprise the Lower Weir beds. Sandstones encountered at 150 to 350 feet above the Sunbury Shale make up the Middle Weir beds and those above 350 feet, the Upper Weir beds (Matchen and Vargo, 1996). Similar positions were set by Zou (1993) for the Lower Weir although he restricted the Middle Weir to 100 to 250 feet above the Sunbury Shale and the Upper Weir at more than 370 feet above. In Doddridge County only the Lower Weir beds are present. 
The Weir zone, however, is not distinguished everywhere into three separate beds. In southwestern Pennsylvania, for example, the Cuyahoga Group consists of interbedded siltstone and shale with some sandstone including an equivalent of the undifferentiated Weir zone (Harper and Laughrey, 1987). At Cramer, Pennsylvania, where the Weir zone crops out, it is described as a fine to coarse sandstone and conglomerate. Sedimentary structures include trough cross-bedding, hummocky stratification, scour surfaces and ripup clasts (Harper and Laughrey, 1989). The Weir sandstone zone was interpreted at Cramer as a marginal-marine sandstone with fluvial conglomerate. Harper and Laughrey (1989) believed this to be deltaic distributary-mouth bar. On the other hand, McDaniel (2006) interpreted the Weir zone west of Cramer as a prograding coastal sandstone, based on the unit's regional thickness and strike orientation and the coarsening-upward trend observed on well logs.

In northern West Virginia at the Rowlesburg outcrop, the Weir zone equivalent is located within the Rockwell Member of the Price Formation. The Rockwell Member consists of a basal conglomerate, a massive sandstone which contains cross-bedding, and a series of shale red beds at the top (Bjerstedt and Kammer, 1988). The Rockwell Member here has been interpreted as a series of distributaries on a delta plain that prograded over the Riddlesburg Shale (Bjerstedt and Kammer, 1988).

At Caldwell in southeastern West Virginia, the Weir zone equivalent comprises 80 feet of sandstone, siltstone, and shale that fine upward (Bjerstedt, 1986). The finegrained sandstone contains hummocky cross-bedding, bioturbated siltstones, and carbonaceous laminae. Bjerstedt and Kammer (1988) interpreted the Price Formation at Caldwell and Bluefield to be fan-slope facies that were sourced from the north. Zou 
(1993) interpreted the Lower Weir sandstone beds as a shelf facies at the Caldwell outcrop in Greenbrier County and as a turbidite facies of a distal fan in Kanawha County.

Correlation by Matchen and Kammer (1994) showed that the Weir sandstone zone is equivalent to the Nancy Member of the Borden Formation in Kentucky. The Nancy Member is composed of greenish to gray silty shale and turbidite sandstone (Matchen and Kammer, 1994). These deeper-marine deposits are representative of the distal facies of the Weir zone. These variations in the Weir reflect regional facies variations that vary depending on their proximity to the source area.

\section{The Lower Weir Beds}

The Lower Weir beds in Ritchie, Doddridge, Gilmer, Braxton, Clay and Nicholas Counties of West Virginia generally range from 0 to 50 feet thick and have a N-S trend (Figure 6) (Zou, 1993). The thickest part of this unit is in southern Doddridge County and northern Gilmer County where it exceeds 100 feet. Zou (1993) interpreted the Lower Weir to be a shelf-edge sand deposited near the slope break into the basin. Contrary to this, Boswell and Jewell (1988) interpreted the strike trend of the Lower Weir to be representative of a submarine fan in deep water. To the east the Lower Weir beds in the subsurface of Preston, Marion, and Taylor Counties were interpreted as a lower fluvialdeltaic plain and distributary-mouth bar (Boswell, 1988). This interpretation was based on the subsurface geometry of the sandstone (Figure 7). The Lower Weir beds there exhibit a strike- and a dip-trend along the interpreted shore. The Middle and Upper Weir beds were not identified in those studies because of erosion related to the pre-Greenbrier 
unconformity. The West Virginia Dome (Figure 7) is an area where Mississippian erosion removed the entire Weir zone (Boswell and Jewell, 1988).

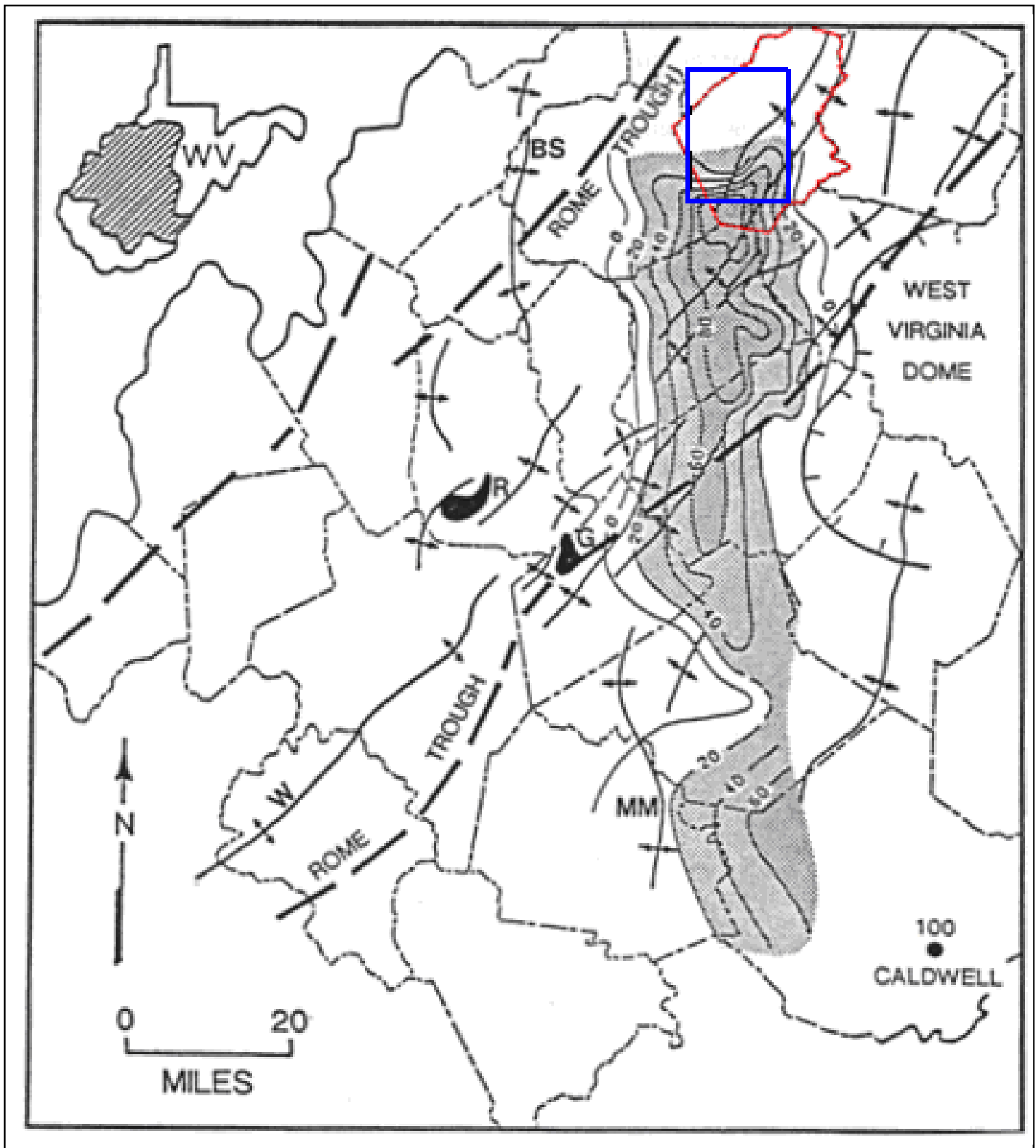

Figure 6: Isopach map of the Lower Weir beds. Local structures are also shown on the map (from Zou, 1993). Doddridge County is shown in red. 


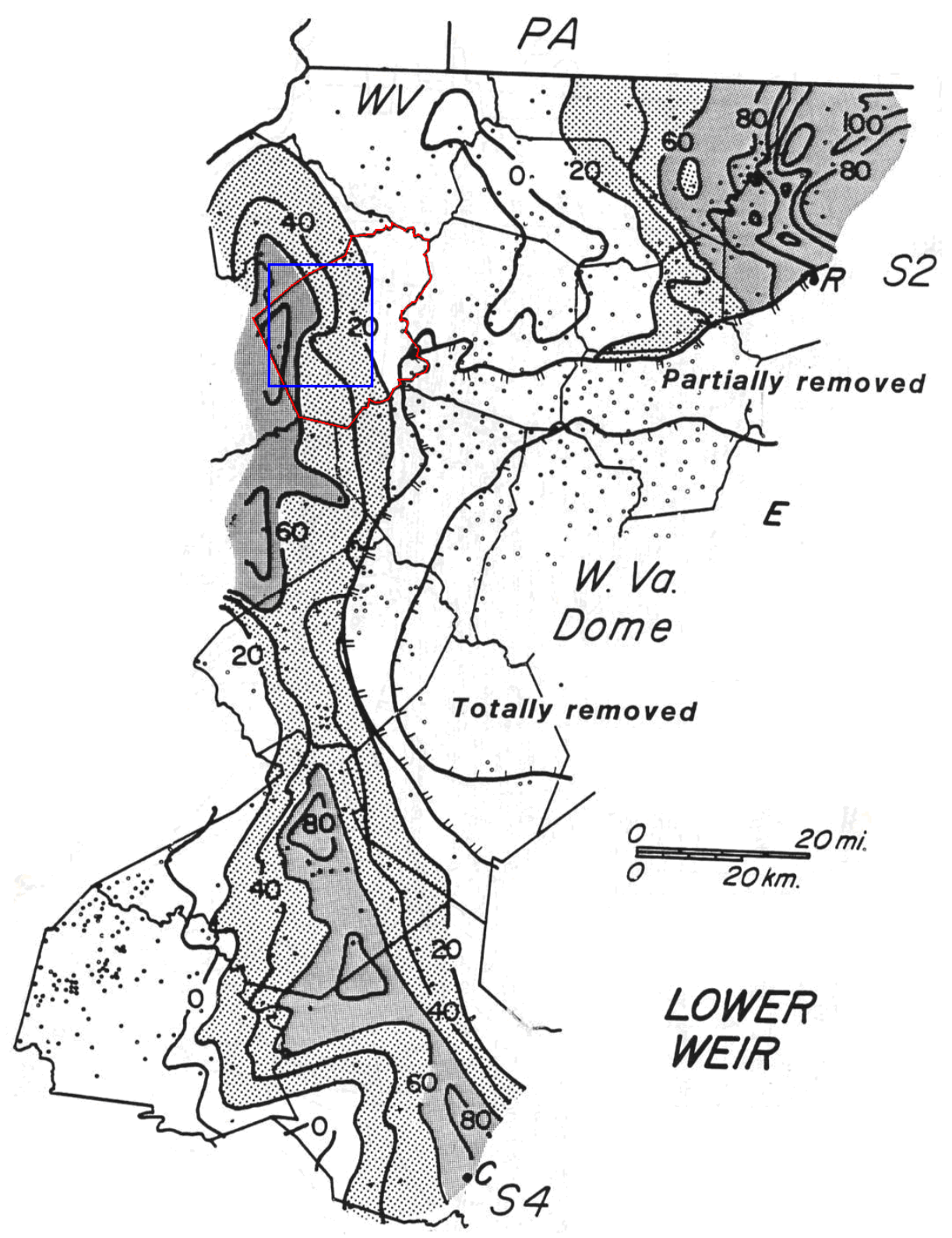

Figure 7: Isopach map of the Lower Weir beds in western and northern West Virginia (Boswell and Jewell, 1988). Doddridge County is shown in red. Blue box shows the approximate study area. 


\section{The Middle Weir Beds}

The Middle Weir beds are between 0 and 100 feet thick, and they have been mapped in the subsurface from Greenbrier to Kanawha and north to Doddridge Counties by Zou (1993). Boswell and Jewell (1988) also identified the Middle Weir sandstone bed in northern West Virginia. The thickness recorded by Boswell and Jewell (1988) in northern West Virginia is less than 50 feet (Figure 8).

The Middle Weir beds were interpreted by Zou (1993) as a barrier-island complex in Kanawha and Boone County based on analysis of a full-bore core. The sandstone, containing large- and small-scale cross-bedding and extensive bioturbation, formed in a tidal channel. Surrounding the Middle Weir bed in the core are shale and siltstone which represent tidal flats behind the barrier island. Water-escape structures in the sandstone and soft-sediment deformation in the surrounding shale are also present (Zou, 1993). 


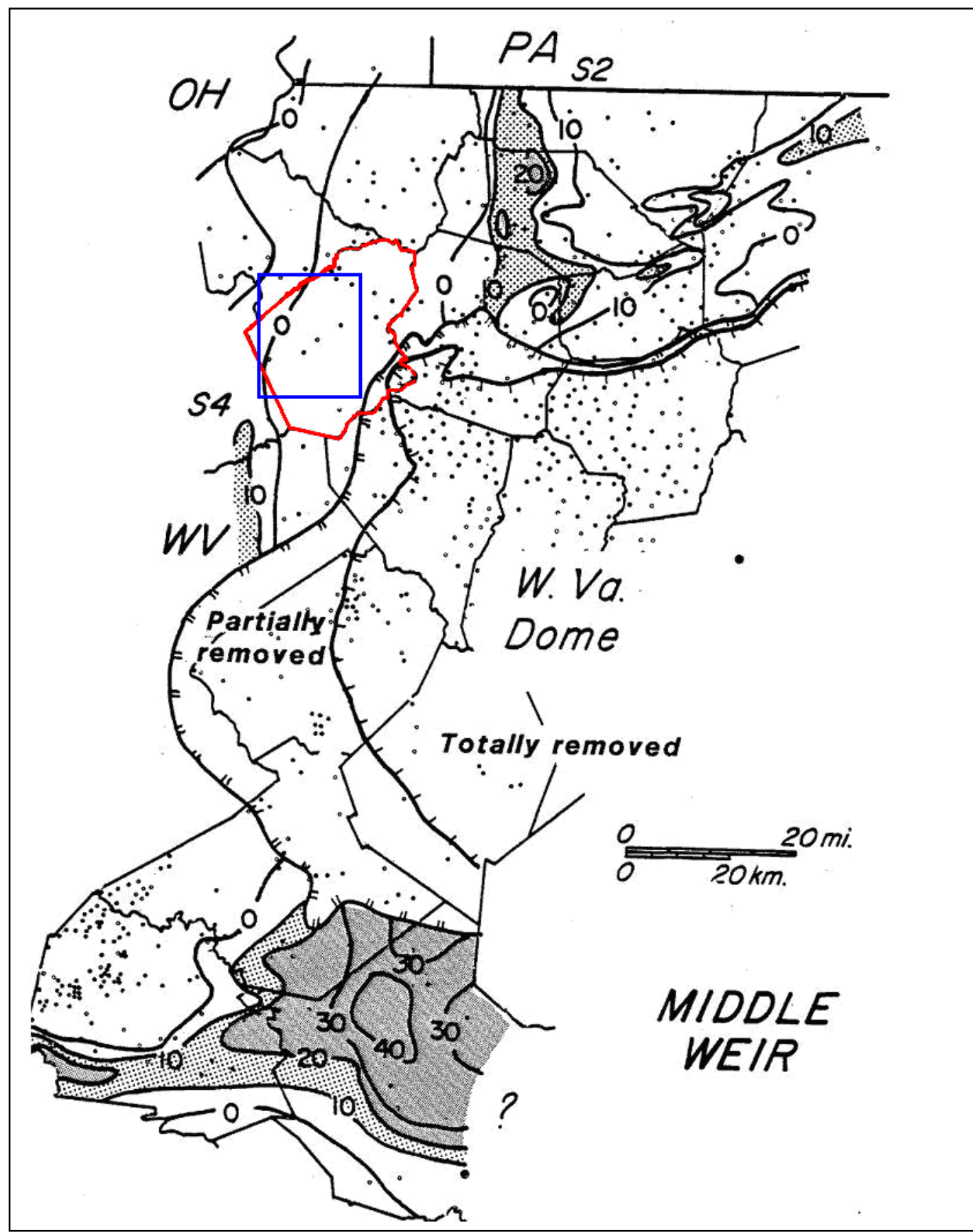

Figure 8: Isopach map of the Middle Weir beds (from Boswell and Jewell, 1988). Doddridge County is shown in red. Blue box shows the approximate study area. 
The Upper Weir Beds

The thickness of the Upper Weir beds range from 0 to 200 feet across Kanawha, Clay, Boone, Fayette, Nicholas, and Raleigh Counties (Zou, 1993) (Figure 9). Boswell and Jewell (1988) mapped a similar extent for the Upper Weir beds; however, their maximum thickness is less than 60 feet.

The Upper Weir outcrops at Caldwell. Boswell and Jewell (1988) termed the unit the Squaw sandstone, but it was later correlated to the Upper Weir beds by Zou (1993). Jewell (1988) concluded that the Upper Weir was a mouth-bar or shoreline deposit in Fayette County. In Boone and Kanawha Counties there are three thick sandstone bodies which trend northeast-southwest that are were interpreted to be barrier-island deposits (Zou, 1993). 


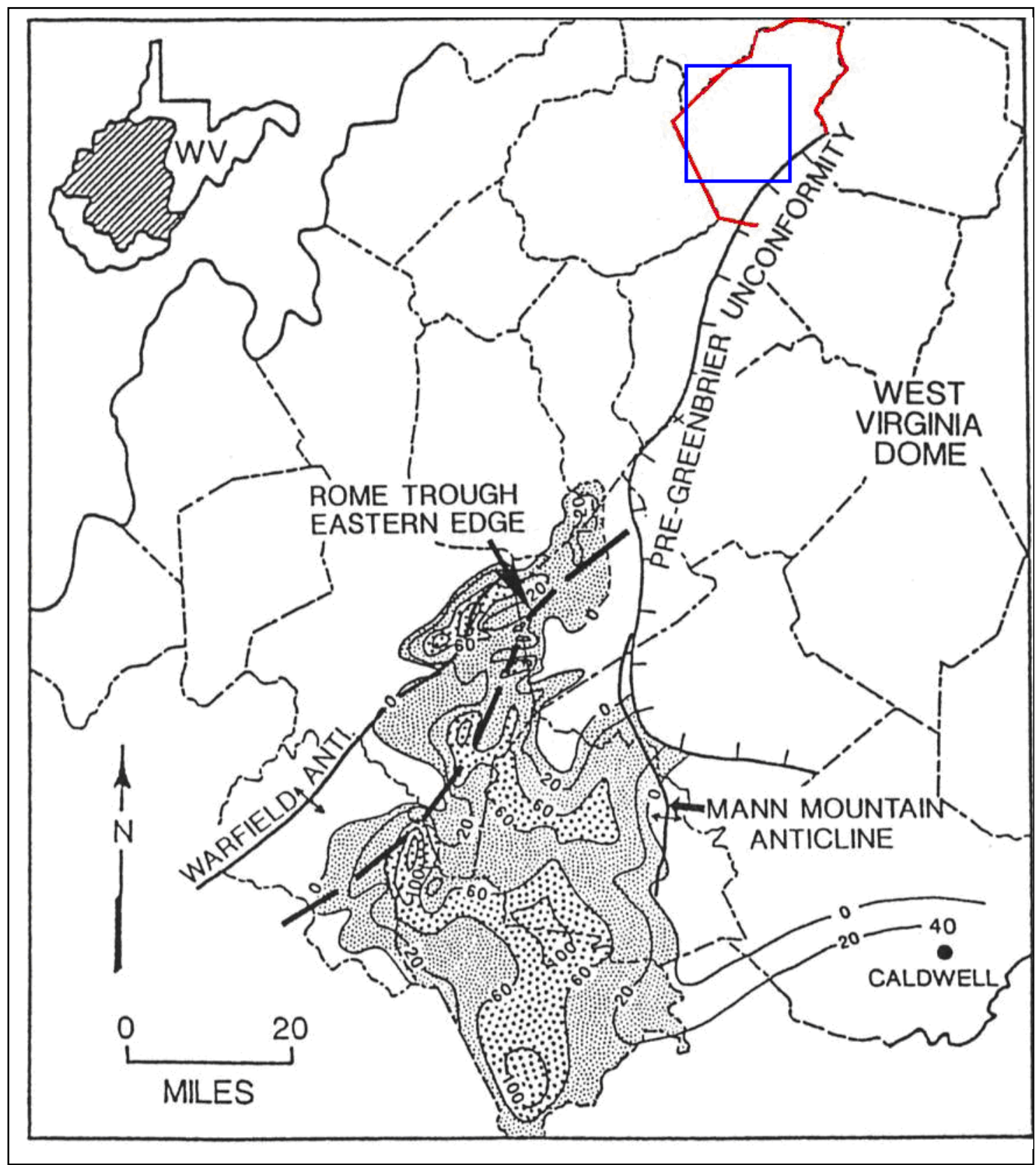

Figure 9: Isopach map of the Upper Weir beds (from Zou, 1993). Doddridge County is shown in red. Blue box shows the approximate study area. 


\section{METHODS}

\section{Well Logs}

Lower Weir beds were identified in the subsurface through the use of well logs. Gamma-Ray logs correlated to the full-bore core of well \#4701705448 were used to determine the extent of the Weir across the study area. In order to correlate the core to the well log, a gamma-ray scintilometer was run after drilling. Results of this test showed that the marked core depth is 18 feet deeper than the well-bore Gamma Ray depth. This 18 foot difference is likely the result of leveling the drilling location and the difference between the

The Lower Weir in Doddridge County, West Virginia, is considered an unconventional reservoir, a fine-grained tight-gas play. The boundary for sandstone on gamma-ray log is typically placed at 60 API units; however, because of an increase in clay content over the Lower Weir, an alternative value had to be chosen. A cut-off line for the sand-silt gamma-ray response in this well was placed at 130 API units to differentiate between reservoir and nonreservoir rock (Figure 10). This number was selected after visual analysis of the gamma - ray curve for well \#4701705448. Thinsection analysis shows that the reservoir rock is primarily siltstone. 


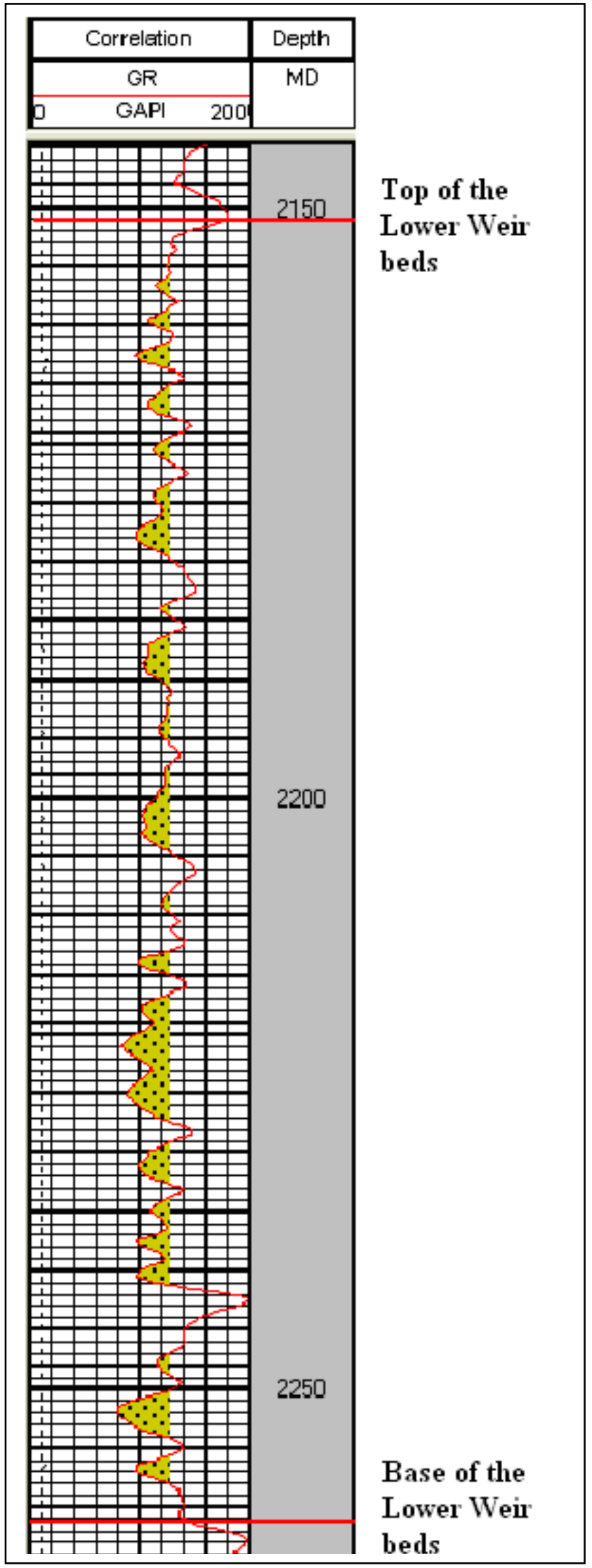

Figure 10: The Lower

Weir beds from well \# 471705448 with a cut-off of 130 API units.

Siltstone is represented by yellow fill. 
The digital data for each well log are contained in a text file. This file has the recorded values for each of the tools that were run at every quarter foot. The GeoGraphix application PRIZM plots these data vertically in the standard well-log view. The advantage of using PRIZM is that it allows for rapid calculations of well-log parameters. Unfortunately, the majority of the data for this study are contained as scanned images which are not in digital format and therefore cannot be analyzed using PRIZM. For all logs the top and base of the Lower Weir were picked where a distinct change in API value occurs.

Porosity is another important variable which can be measured across the study area. A higher porosity value is generally sought to determine the best locations for drilling, for it is commonly an indicator of permeability when used in conjunction with an audio and temperature response. Porosity was measured using the Bulk Density tool, measured in nearly every well in the study area. Values are measured using Zone Manager which is an application of GeoGraphix that allows for the thickness of a particular variable to be measured for any given zone of interest. One advantage of using this application is that it can accurately record data for both digital and tiff images (Figure 11). Isolith maps of siltstone with porosity greater than $8 \%(2.55 \mathrm{~g} / \mathrm{cc})$ and $6 \%$ $(2.60 \mathrm{~g} / \mathrm{cc})$ were generated. These values were picked because siltstone with porosity less than $6 \%$ is of too poor reservoir quality and rarely stimulated. Siltstone porosity greater than $8 \%$ is infrequent and cannot be mapped with consistency across the study area, but may be used to highgrade infill drilling locations in the future. 


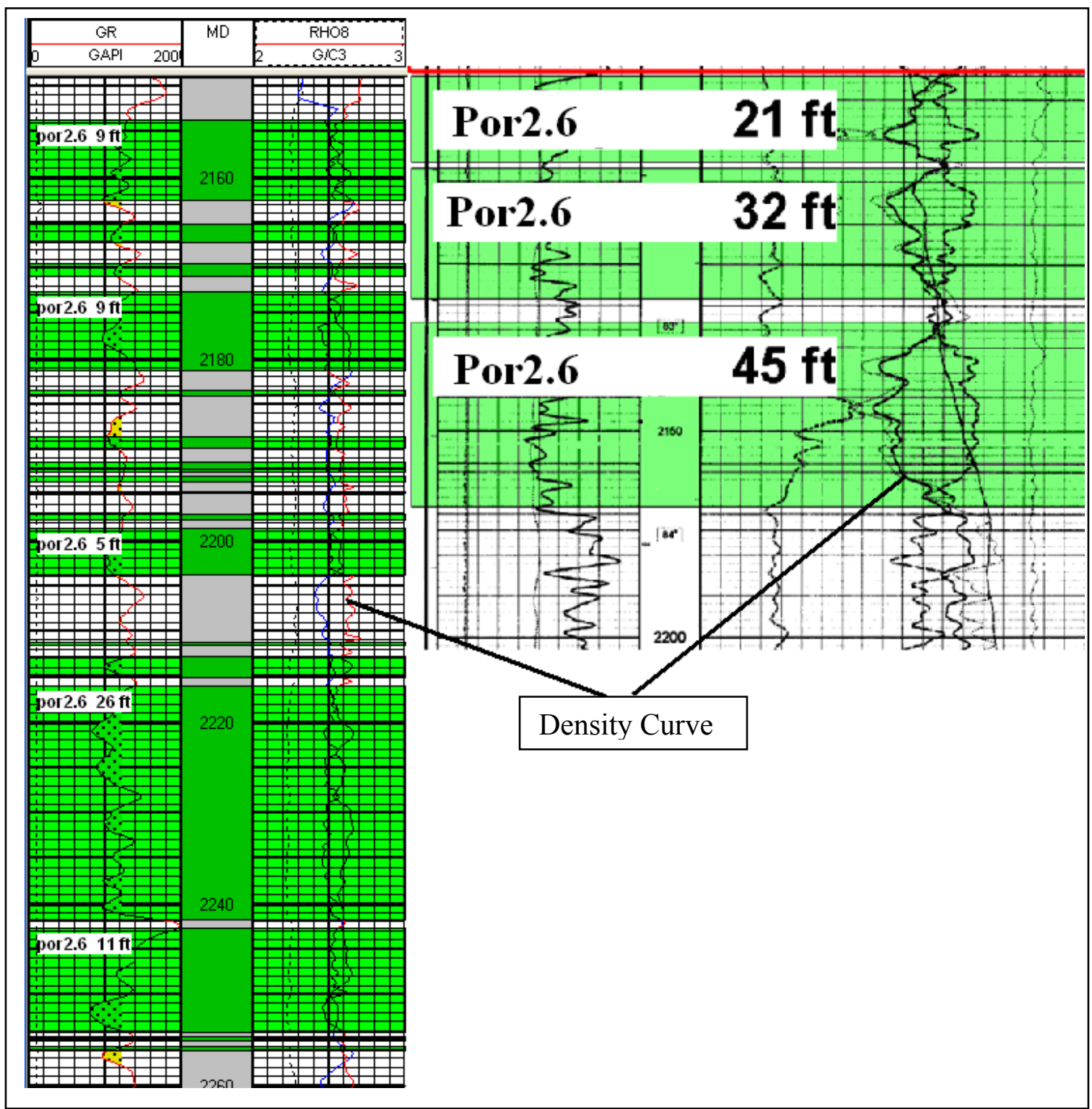

Figure 11: Zone Manager application highlights the zone of interest (green) within a selected well. This figure shows both the vector well \# 4701705448 and the tif well \# 4701705074. 


\section{Measured Well-Log Parameters}

Analysis of a digital well log can be preformed rapidly using programs like GeoGraphix or PETRA. These programs can be used to calculate certain reservoir properties, for example water saturation using the Archie Equation. Other useful and interesting well-analysis techniques include the Pickett plot and the RHOmaa - Umaa plot. The Pickett plot graphically shows water saturation in varying portions of the zone of interest. The RHOmaa - Umaa plot indicates mineral content of the formation by comparing the response of different logging tools against known values for certain minerals. By calculating these different parameters, zones of interest within the Lower Weir beds can be identified. These analytic techniques can be performed on Excel through equation manipulation or with the aid of the PfEFFER module (Kansas Geologic Survey, 2007).

The RHOmaa - Umaa crossplot was designed to compare well-log signatures for a select zone and to differentiate between mineral and clay types. RHOmaa is the apparent matrix density and Umaa is the apparent matrix photoelectric absorption coefficient. The crossplot compares the response of the photoelectric, neutron porosity and bulk density tools and plots the response on a triangle cross-plot whose end points consist of minerals the values of which are already known (Doveton, 1994). The Lower Weir beds in well \#4701705448 occur from depths 2150 to 2262 feet (Figure 12). The photoelectric, neutron-porosity and bulk-density logs were compared to determine the mineral make up of this unit in terms of quartz, potassium feldspar, and illite. 


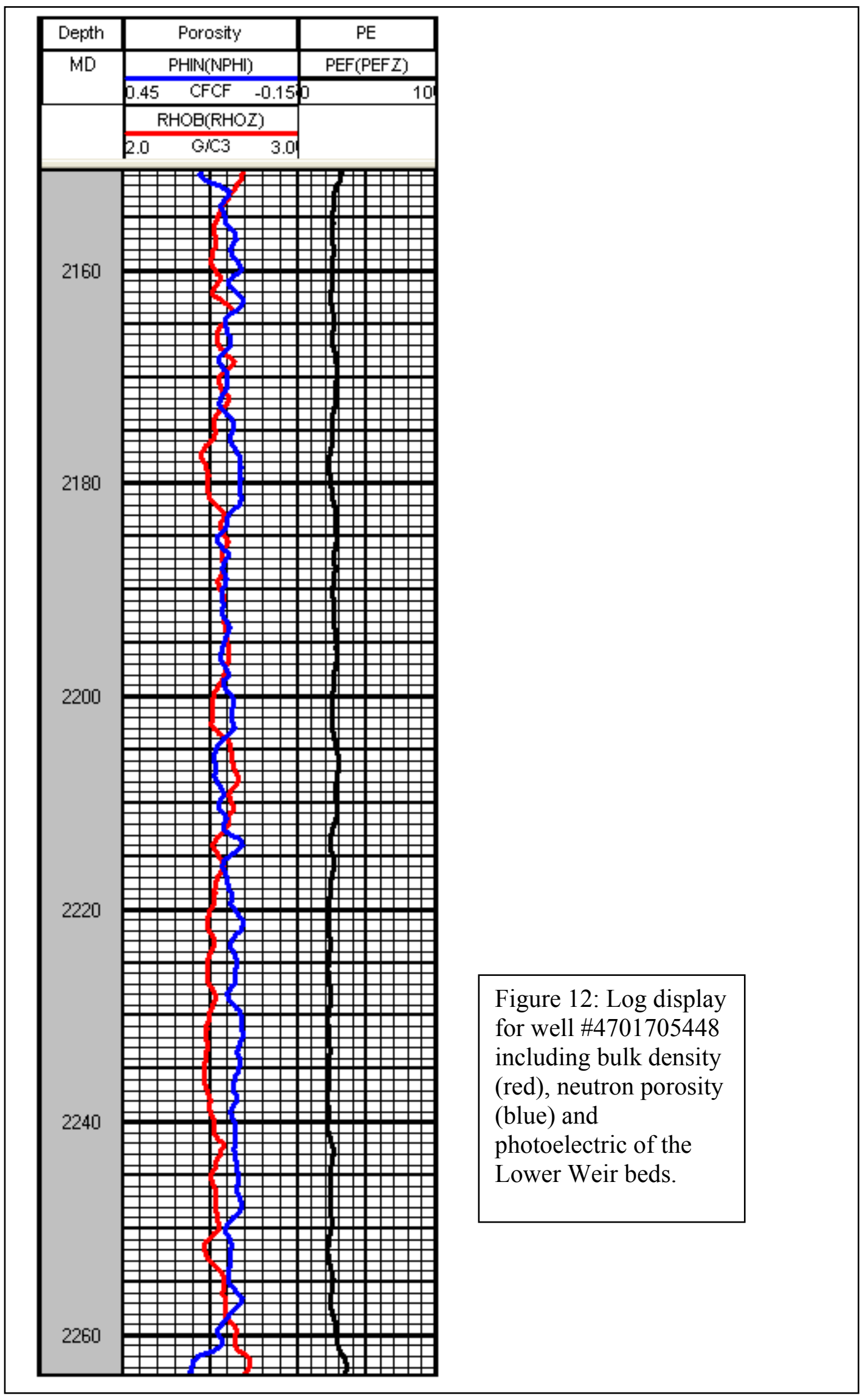


The Archie formula (Equation 1) allows for the calculation of water saturation using the Archie Equation (Equation 2) within a zone of interest. This calculation will enhance the likelihood of success by identifying specific zones for completion that have low water saturation and, conversely, a higher oil and gas saturation (Doveton, 1994). For example, zones within a formation that have high water saturation (80 - 100\%) should not be fracture stimulated; only zones with the lowest calculated water saturation (less than 40-50\%) should be stimulated.

\begin{tabular}{|l|}
\hline \multicolumn{1}{|c|}{ Equation 1: $\mathrm{F}=\mathrm{a} / \Phi^{\mathrm{m}}$ (Selley, 1998) } \\
Equation 2: $\mathrm{S}_{\mathrm{w}}=\left[\left(\mathrm{a} / \Phi^{\mathrm{m}}\right) *\left(\mathrm{R}_{\mathrm{w}} / \mathrm{R}_{\mathrm{t}}\right)\right]^{(1 / \mathrm{n})}$ (Doveton, 1994). \\
- $\mathrm{S}_{\mathrm{w}}$ : water saturation, recorded in percent \\
- $\Phi_{\text {: porosity, a composite from the neutron porosity, and bulk }}$ \\
- density logs \\
- $\mathrm{R}_{\mathrm{w}}$ : formation water resistivity, this is calculated from the \\
porosity logs \\
- $\mathrm{R}_{\mathrm{t}}:$ recorded bulk resistivity from the down hole logging tool \\
- $\mathrm{a}$ : constant $(.81$ for consolidated sandstone) \\
- $\mathrm{n}$ : saturation exponent (another constant, also of 2$)$
\end{tabular}

The values for $a$ and $m$ are difficult to calculate and are related to the convoluted path of pore space within the sample. Therefore, constants have been assigned to these values based on lab testing of different matrix types. The porosity value $(\Phi)$ is simply a composite value derived from the wireline log data (Equation 3). Rt is acquired from the deep-induction well log. $R w$ is the resistivity of water at the formation depth (Selley, 1998). $R w$ was measured from a water sample in a nearby Weir only well. 
Equation 3: PHIA $=[((\mathrm{NPOR}+\mathrm{DPH} 8) / 2.0) * 100]$

- PHIA: Average Porosity

- NPOR: Enhanced Thermal Neutron Porosity

- DPH8: High Resolution Density Porosity

\section{Formation MicroImager Analysis}

Schlumberger's Formation MicroImager (FMI) was available through the logging of well \#4701705448. The FMI records the resistivity of the zone of interest at a high resolution; vertical variations in resistivity can be seen within a zone as small 0.2 inches (Schlumberger, 2002). The data are recorded digitally and then displayed graphically on a $\log$ where a color scheme indicates which units are resistive and which units are conductive. These variations can be used to identify structural, lithologic, and stratigraphic information such as cross-bedding, fractures, and the overall dip of the zone of interest. Sandstone is a resistive unit when compared to shale and is represented on the FMI by a lighter shading of yellow. The FMI becomes darker as sandstone becomes more clay-rich or shale-rich and indicates an increase in conductive material.

Several tracks are displayed on an FMI log. One track is the static current map image. The static image compares the absolute maximum and an absolute minimum resistivity value recorded within the borehole and compares these values to the resistivity value at any specific depth (Schwartz, 2006). This deviation in resistivity causes significant difference in color on the static current image where the lithology changes. A static current map is therefore useful when trying to differentiate between lithologic 
boundaries, that is, sandstone and shale within and around the Lower Weir beds in well \#4701705448.

The second resistivity track is the dynamic current map; it is used to identify small-scale features such as cross-bedding. This curve displays the resistivity measurements of the borehole, but the maximum and minimum values are recorded and rerecorded at a one-inch interval. This technique allows for small variations in the resistivity to be seen within a narrow zone.

Fractures within the formation of interest are identified on the dynamic current image, the third track, and they appear as a sinusoidal feature. If a fracture is filled with cement (primarily quartz or calcite), it has a resistive signature represented on the FMI $\log$ by a light color. Fractures on the FMI log that appear dark are filled with mud and are conductive (Schwartz, 2006). The mud is an after-product of the drilling process. 
Core Porosity and Permeability

Core porosity and permeability values were obtained from core plugs taken from the Lower Weir beds in well \# 4701705448. These plugs were analyzed by CoreLab. The data were adjusted to fit the logging depths by graphically displaying the logporosity data by depth and comparing it to the core-porosity data. Eighteen feet was subtracted from the core depths; this result was similar to the adjustment made on the gamma-ray curve mentioned previously (Figure 10). Porosity and permeability data were then graphically displayed using PETRA.

The calculation for average porosity was made at every quarter-foot depth interval (Equation 3). Data was collected every three inches which is the vertical resolution of the logging equipment. This equation and plot showed that similar values were obtained for porosity by using either the core or well - log data for Lower Weir siltstones. The low porosity values above and below the Lower Weir indicate the shale beds surrounding the unit. 


\section{Petrographic Thin Section and Core Analysis}

Fifteen thin sections were examined through the Lower Weir beds from well \#4701705448. These thin sections were cut from depths 2159.15 to 2257.35 feet. These were prepared by CoreLab of Houston, Texas, stained with Alizaren red to identify calcite, and impregnated with blue plastic to improve the visibility of porosity. Microscope analysis was limited to the determination of grain size and porosity. Future studies could examine these thin sections to analyze the Lower Weir beds for mineral content, texture, matrix, and cement, but such examination was beyond the scope of this study.

The 150- foot core was slabbed by CoreLab of Houston, Texas. This core was examined in conjunction with the FMI log provided by Schlumberger. Sections of the core were placed next to the FMI log, and visual similarities were recognized between the two. Analysis of the core showed three general rock types, claystone, fine siltstone and coarse siltstone. These rock types are visiably identified on the static current map image of the FMI log. Therefore, both the FMI log and core were used in distinguishing lithofacies. 


\section{RESULTS}

Results concerning the petrology, thickness, depositional environment, porosity and structure of the Lower Weir beds were obtained through the analyses of core and well-log data. Petrographic analysis for the Lower Weir beds was obtained through a combination of well logs (including the FMI), thin sections, and the core itself.

Thickness of the Lower Weir beds across the study area was determined through analysis of gamma-ray well-log data. Depositional environment interpretations were made based on rock types, sedimentary structures, and fossils in the core and the FMI log of the Lower Weir beds, and through regional mapping of the unit. Porosity interpretations across the study area were obtained through inspection of well logs and thin sections; porosity and permeability data were also obtained from the core. Structure interpretations were derived from well-log data across the study area and the FMI log of the cored well.

\section{Petrology}

The boundaries of the Lower Weir beds can be identified on the FMI log. The base of the Lower Weir beds is at 2261.5 feet. This contact was identified on the static current map image as an abrupt change from conductive material, shale, to a more resistive material, siltstone. An abrupt change was also identified at the top of the formation on the FMI log at 2152 feet (Figure 13). 


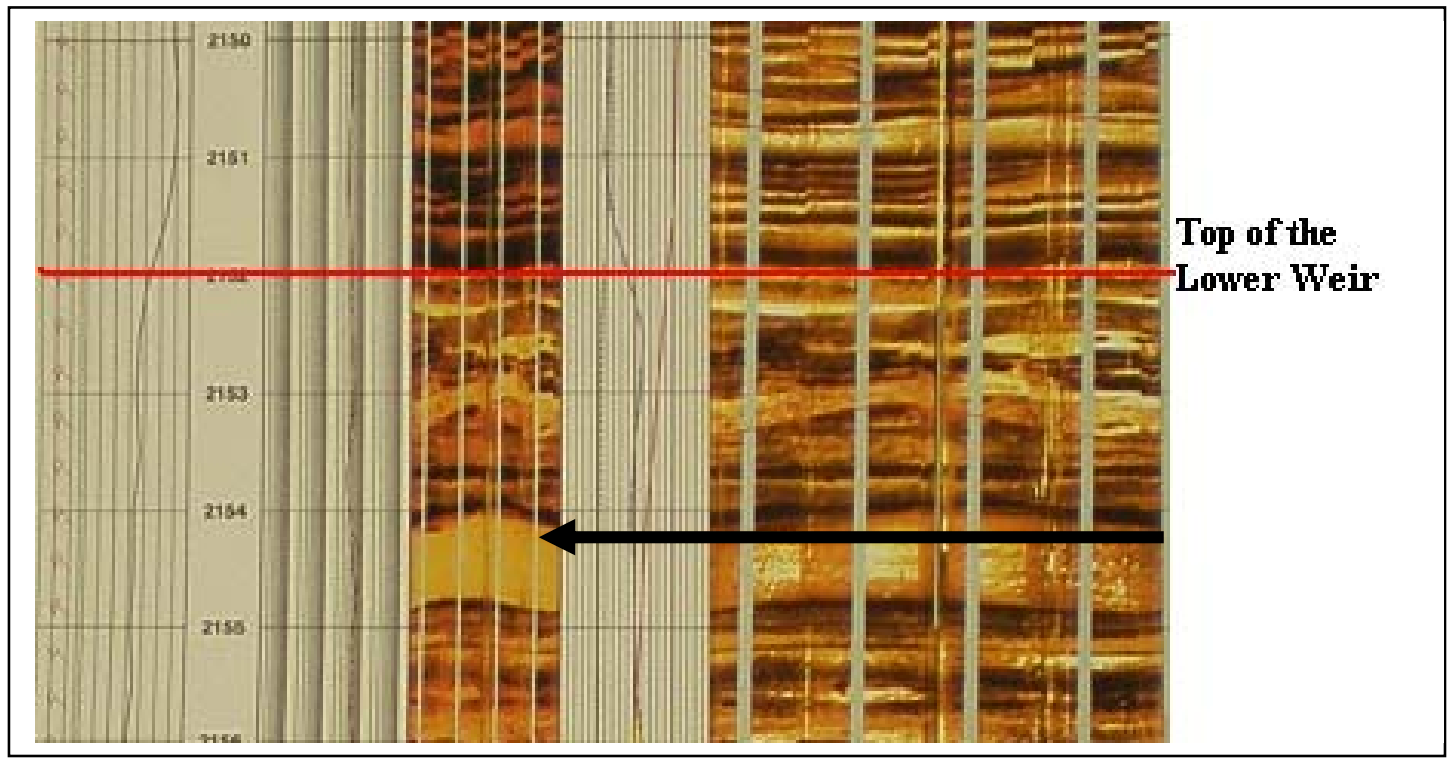

Figure 13: FMI log showing the top of the Lower Weir beds at 2152 feet. The transition from the shale above (dark) to siltstone below (light) is easy to see on the middle track which shows the static current map image. An arrow designates the middle track.

Mean grain size was calculated from the size of 25 random grains in each thin section; the data are present in Figure 14. Grain size ranges from a maximum of 34.8 microns (very coarse silt) to a minimum of 16.2 microns (coarse silt) (Figure 15). Because of the fine - grained texture of the Weir zone, measurements were taken at high magnification in cross-polarized light to emphasize the grain boundaries (Figure 16). 
Figure 14: Grain-size data from 15 Lower Weir thin sections.

\begin{tabular}{|c|c|}
\hline $\begin{array}{c}\text { Depth } \\
(\text { Feet })\end{array}$ & $\begin{array}{c}\text { Mean Size } \\
(\mu)\end{array}$ \\
\hline 2159.2 & 32.0 \\
2166.3 & 30.9 \\
2178.3 & 30.5 \\
2187.5 & 26.3 \\
2190.3 & 27.1 \\
2194.2 & 22.9 \\
2201.3 & 28.4 \\
2209.3 & 16.2 \\
2222.3 & 29.8 \\
2226.3 & 29.9 \\
2230.2 & 32.7 \\
2235.2 & 34.8 \\
2247.3 & 24.6 \\
2253.3 & 34.3 \\
2257.4 & 29.4 \\
\hline
\end{tabular}



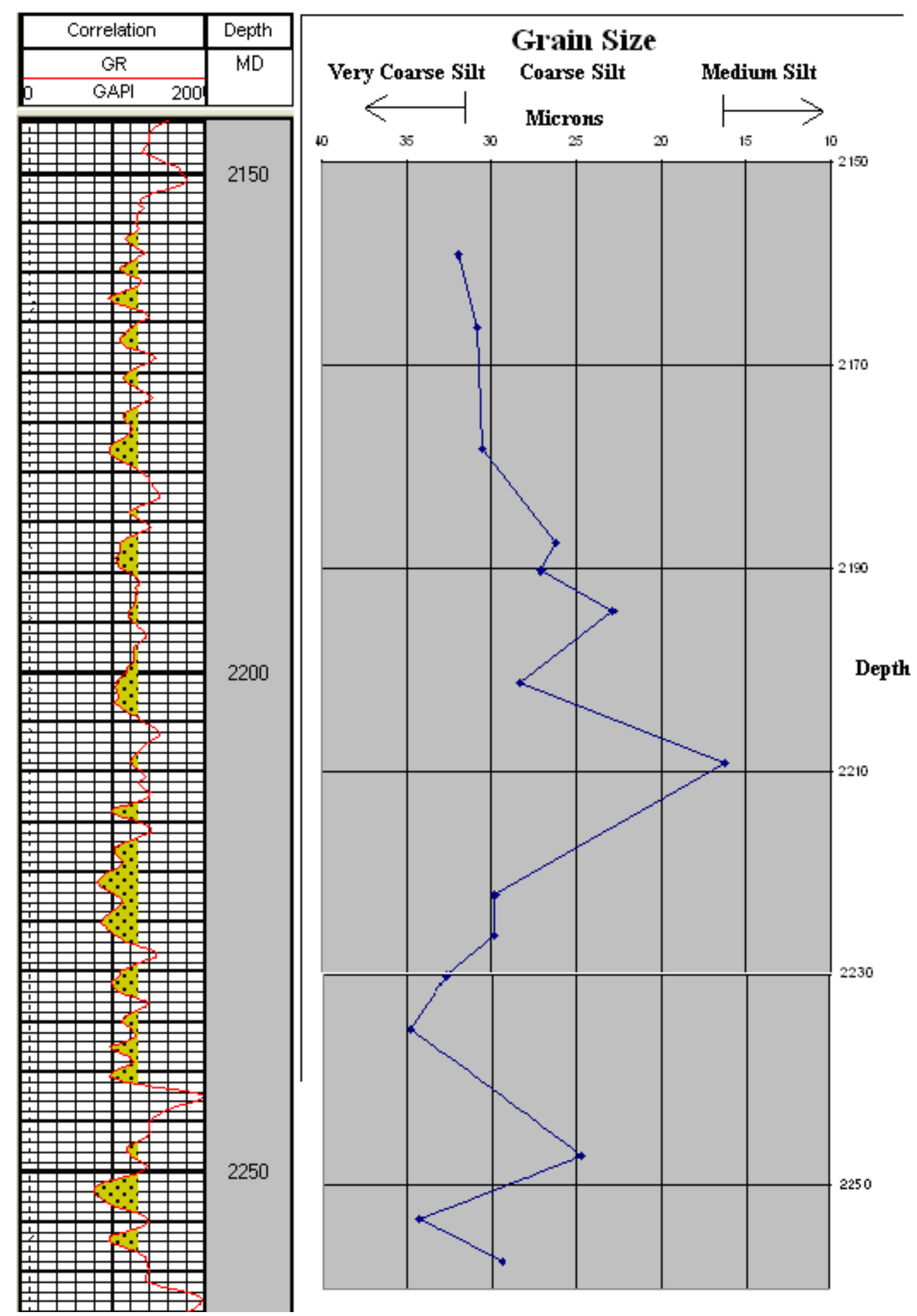

Figure 15: Mean grain size for the Lower Weir plotted against depth. The gamma-ray curve is included for comparison. 


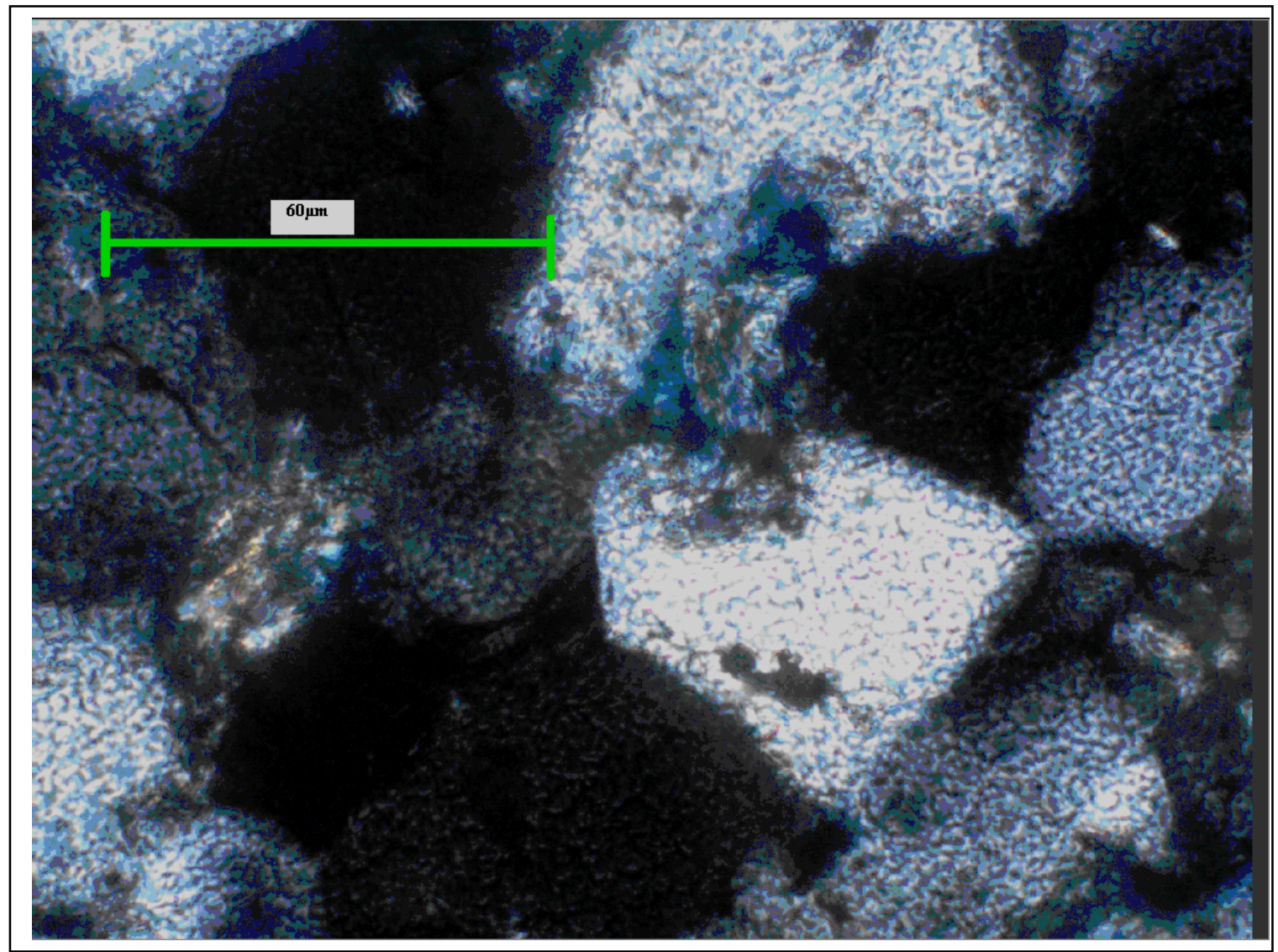

Figure 16: Photomicrograph of the Weir sample at 2178.25 feet. Grains in the field of view are very coarse silt size. Bar scale is 60 microns.

Mineral data for the Lower Weir beds, as suggested by RHOmaa - Umaa crossplot, fall mainly between the values for quartz, illite, and potassium feldspar suggesting that this unit is an arkosic wacke (Figure $17 \mathrm{a}, \mathrm{b}, \mathrm{c}$ and d). Examination of the thin sections taken over the Lower Weir beds shows little feldspar. Secondary minerals of the Lower Weir can account for a shift in data. Secondary minerals (muscovite, dolomite, and calcite) were plotted on the table as well. Small volumes of natural gas cause the data to plot higher on the Rhomaa axis, likewise shifting the cloud of data points towards the feldspar end-member.

The data which extend towards the illite end-member (Figure $17 \mathrm{a}-\mathrm{d}$ ) are representative of the clays within the Lower Weir. Thin sections show an abundance of 
clay matrix plus numerous lutite rock fragments. Clay matrix within the Weir pore spaces could cause problems for gas production. During treatment and production these particles (called "fines") could become dislodged and clog pore throats, which would then prevent the flow of gas. The RHOmaa - Umaa cross plots also show (Figure $17 \mathrm{a}-$ d) an increase in illite from the base to the top of the Lower Weir.

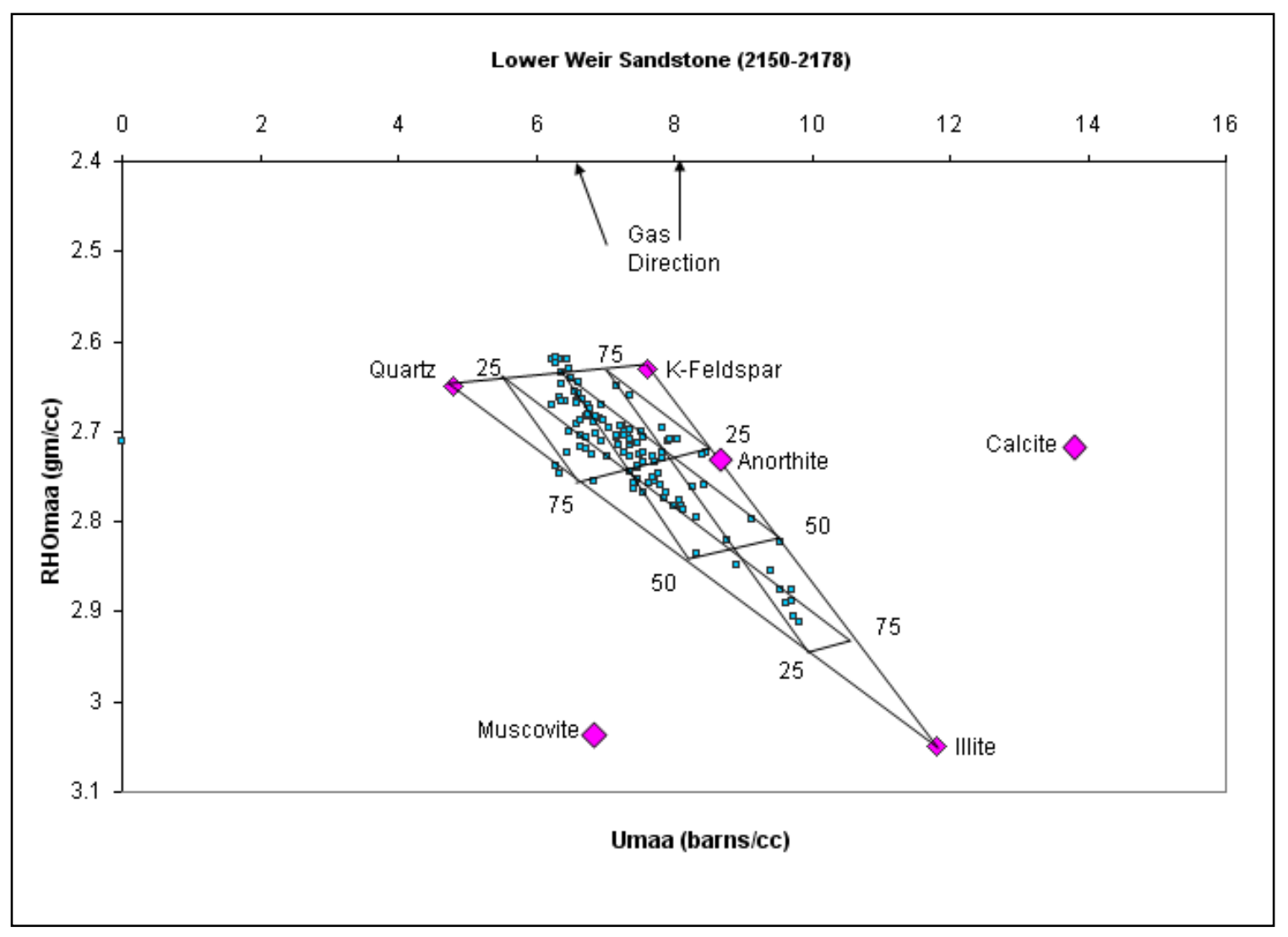

Figure 17a: RHOmaa-Umaa crossplot that graphically shows the mineral make up of the Lower Weir $(2150-2178$ feet). 


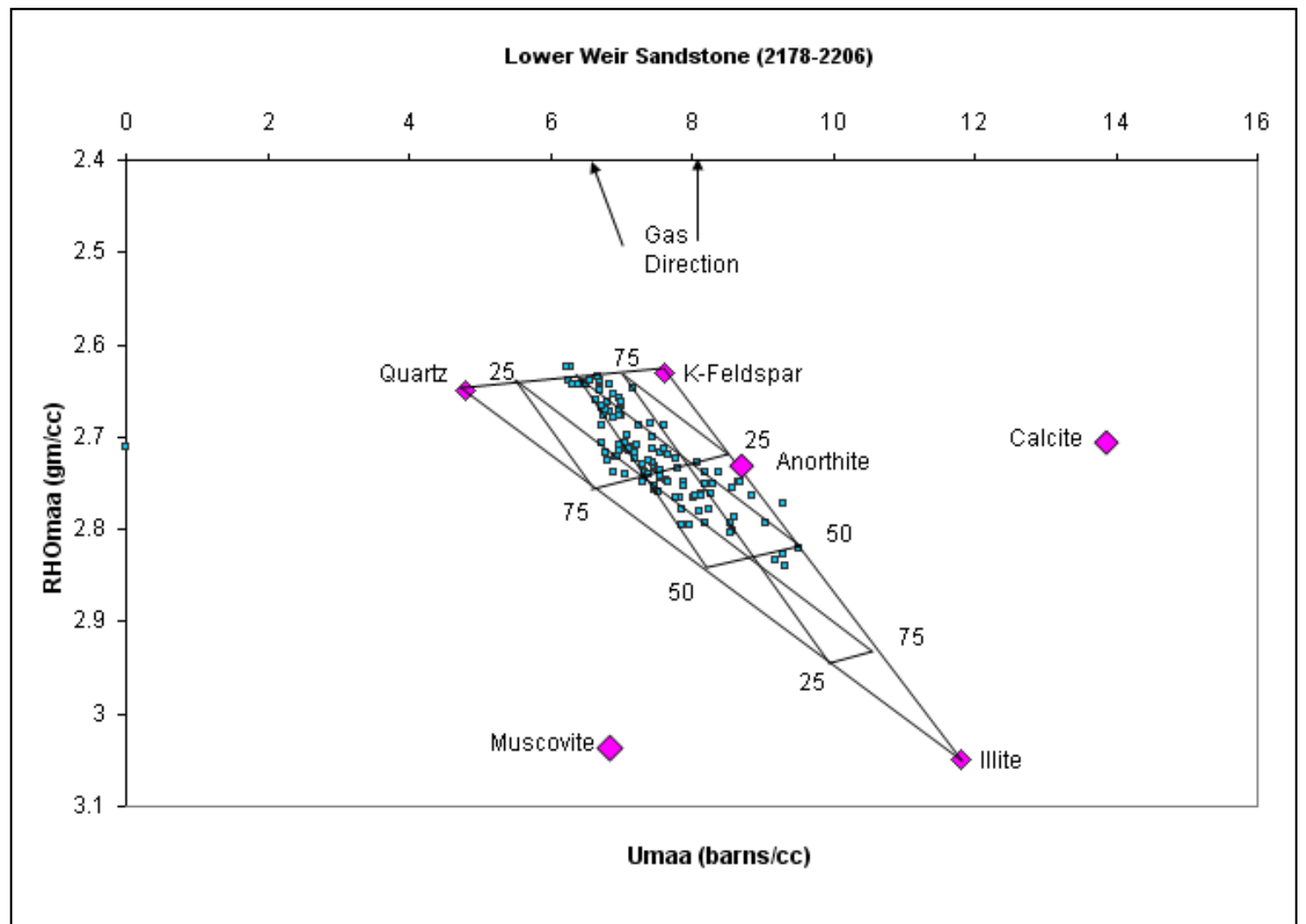

Figure 17b: RHOmaa-Umaa crossplot that graphically shows the mineral make up of the Lower Weir $(2178-2206$ feet $)$.

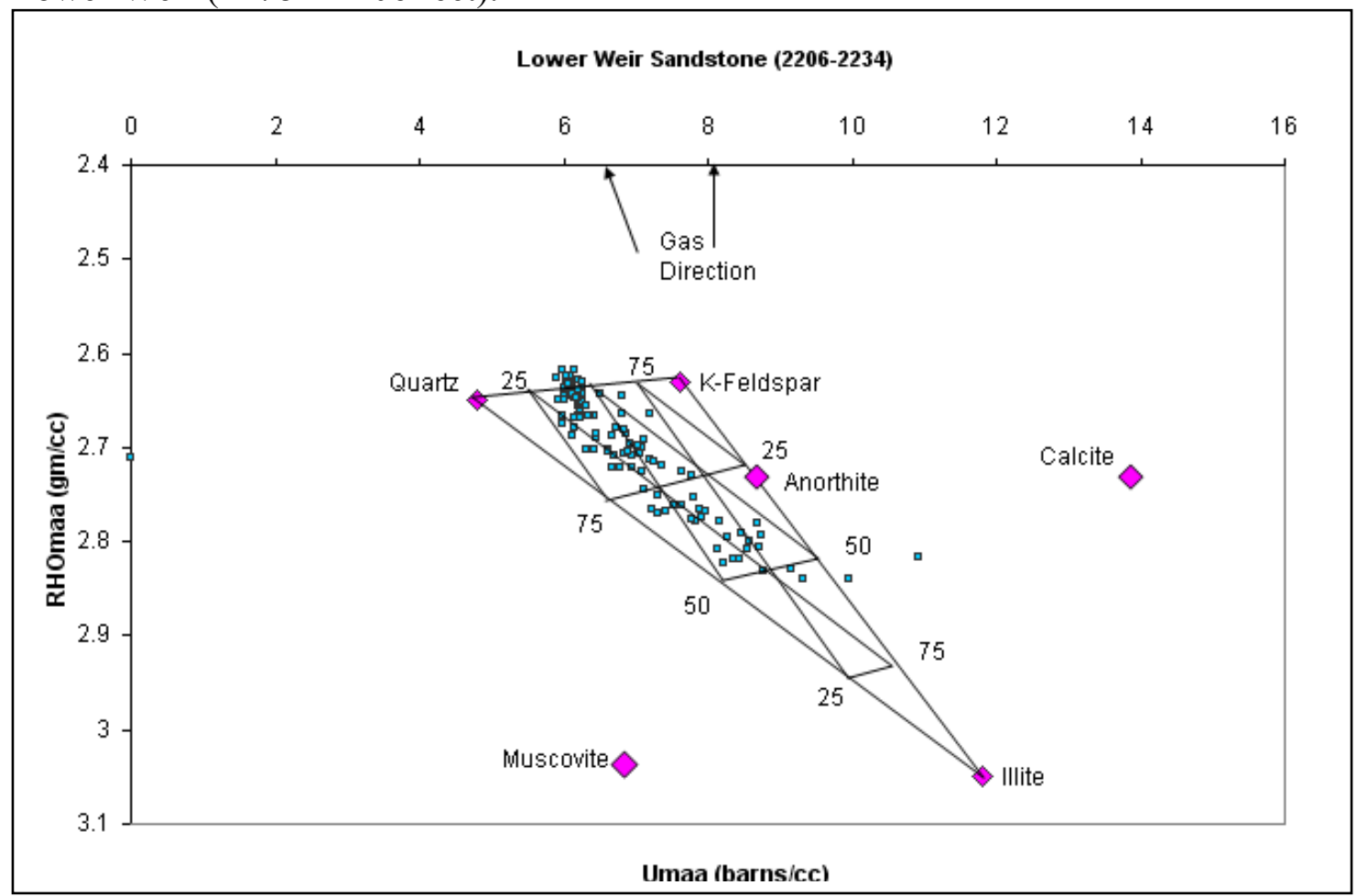

Figure 17c: RHOmaa-Umaa crossplot that graphically shows the mineral make up of the Lower Weir (2206 - 2234 feet). 


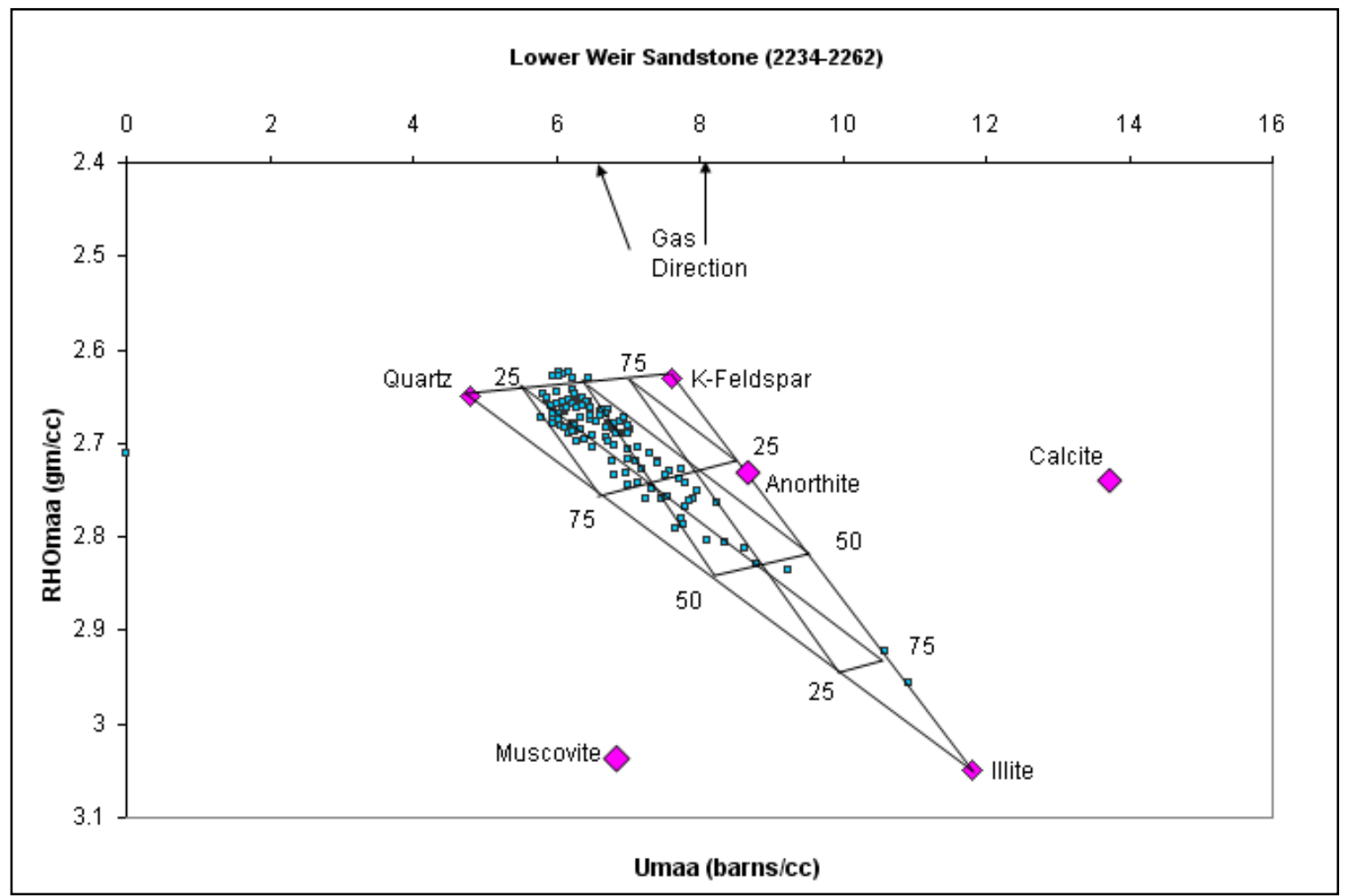

Figure 17d: RHOmaa-Umaa crossplot that graphically shows the mineral make up of the Lower Weir (2234 - 2262 feet).

The static current map image of the cored well shows that within the Lower Weir beds slight changes in rock type can be seen as well as large-scale changes. Subtle differences exist between coarse siltstone (Figure 18), fine siltstone (Figure 19) and claystone (Figure 20). These three lithofacies accurately describe the rock types that occur within the Weir zone. 


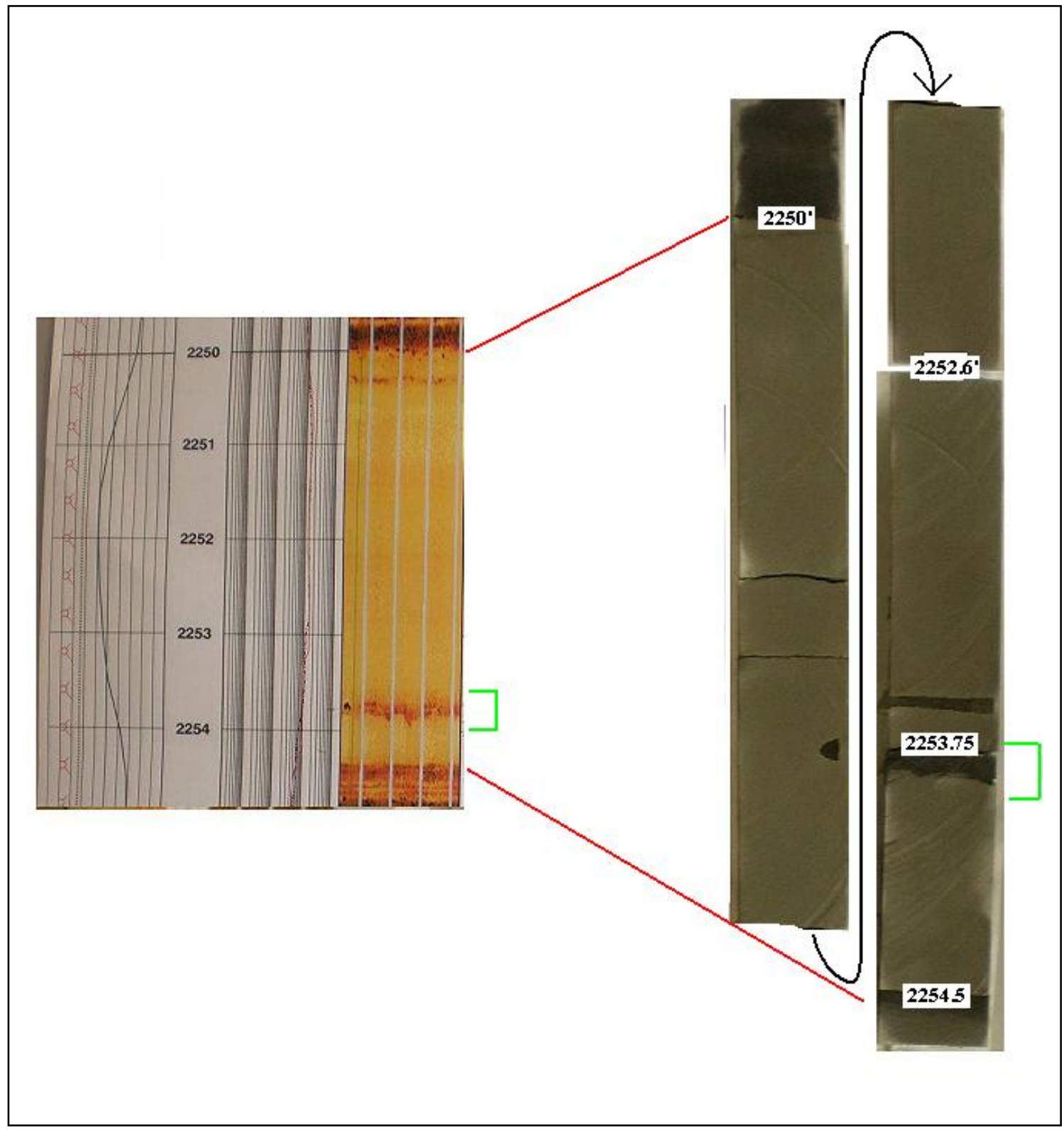

Figure 18: FMI log and slabbed core showing a typical coarse siltstone package within the Lower Weir, approximately four feet thick. A three inch fine siltstone occurs near the base of this section (green bracket). 


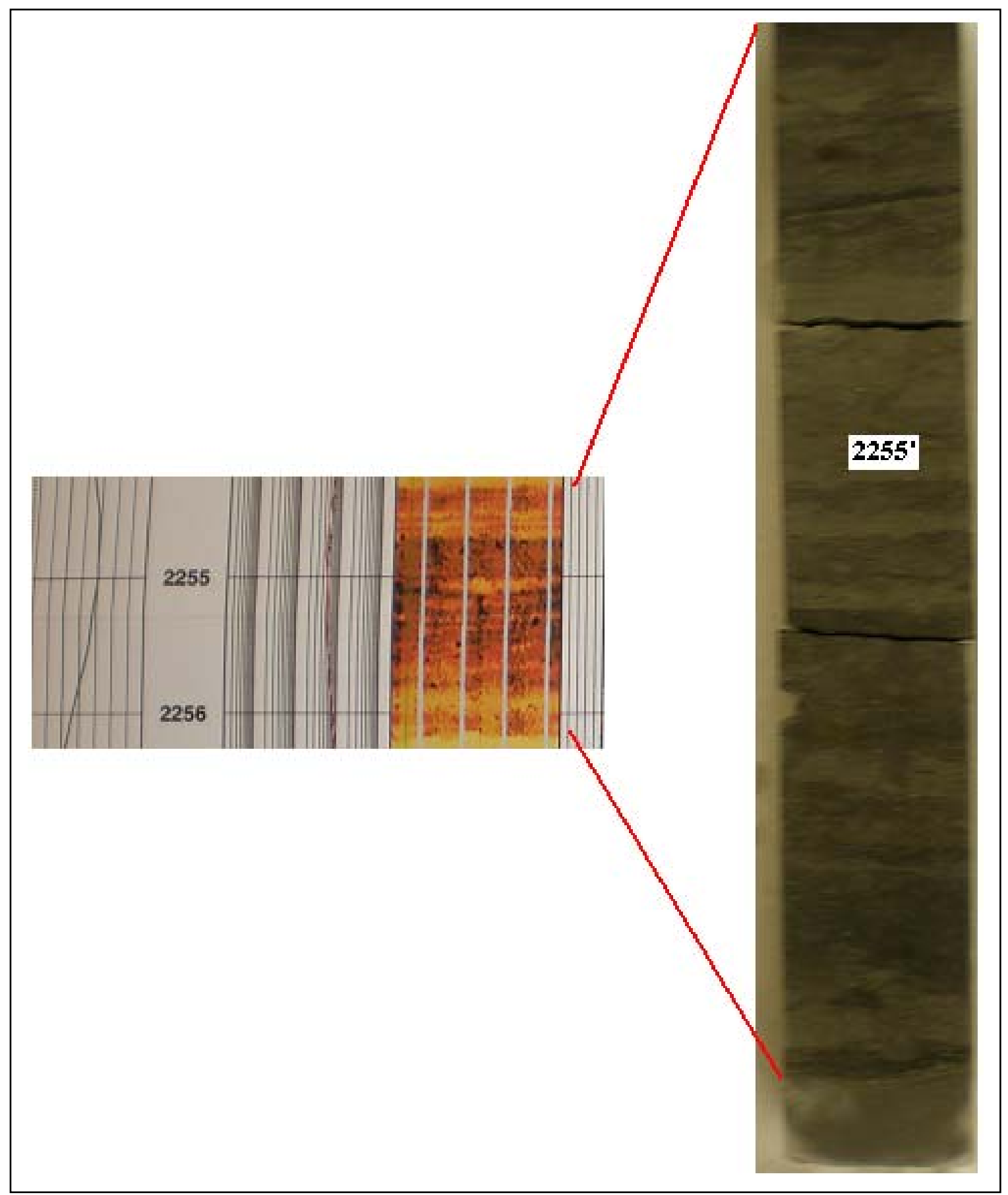

Figure 19: FMI log and slabbed core showing a typical fine siltstone within the Lower Weir, approximately 2 feet thick. This unit is burrow mottled. Core is four inches wide 


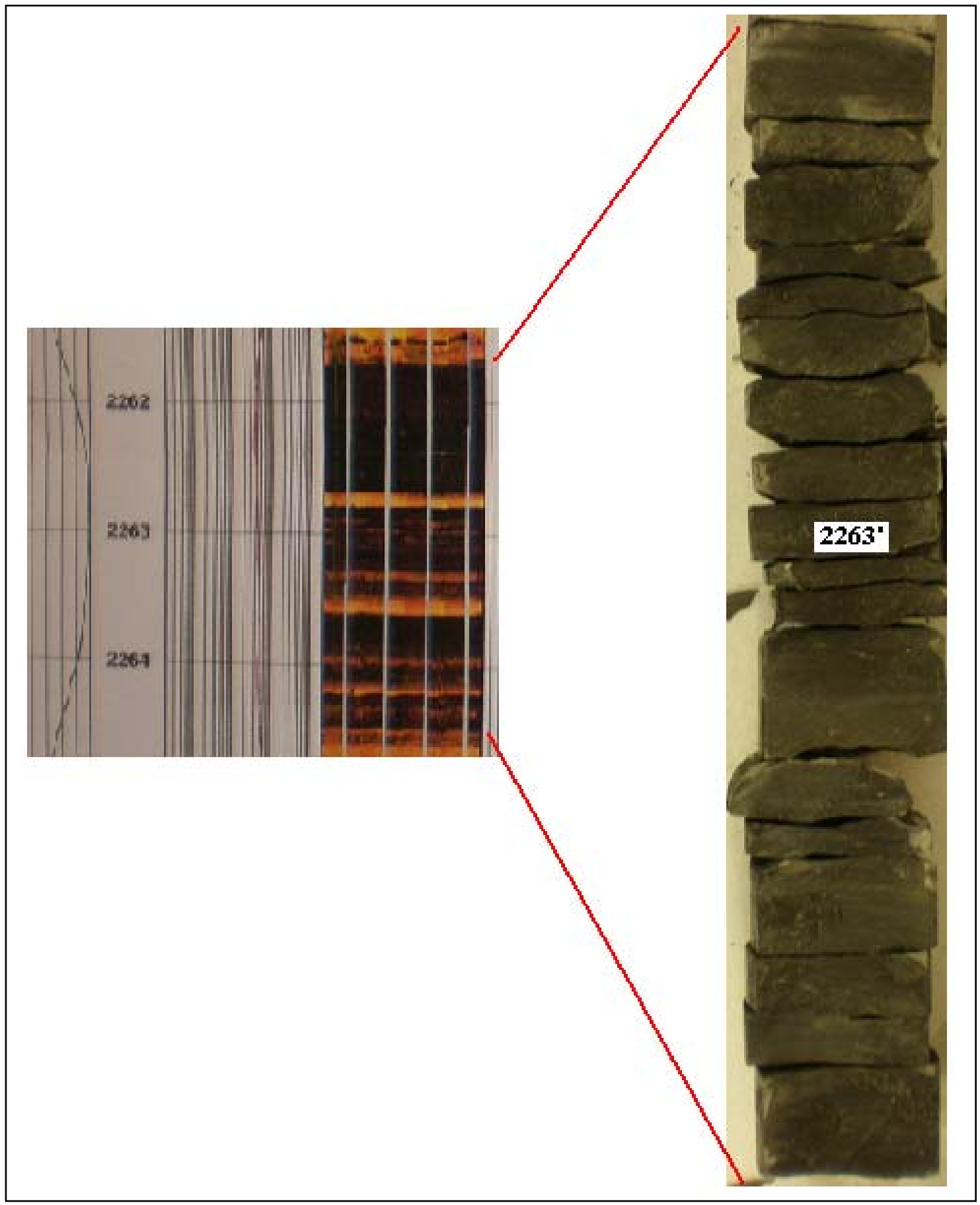

Figure 20: FMI log and slabbed core showing a typical claystone within the Lower Weir, approximately 3.5 feet thick. Core is four inches wide 
Coarse siltstone, fine siltstone and claystone are seen throughout the Lower Weir beds (Figure 21). Figure 22 shows the distribution of these three lithologies as they were identified on the FMI log and the corresponding core depth. Analysis showed a finingupward pattern that is present throughout the Lower Weir beds. This is represented by a decrease in coarse siltstone (that is, thickness of individual beds and cumulative thickness) towards the top of the formation and conversely an increase in fine siltstone and claystone. Superimposed on this overall change in grain size is a series of five coarsening upward parasequences that range in thickness from 13 - 32 feet (figure 22). Sedimentary features of the three lithofacies are summarized in Figure 23.

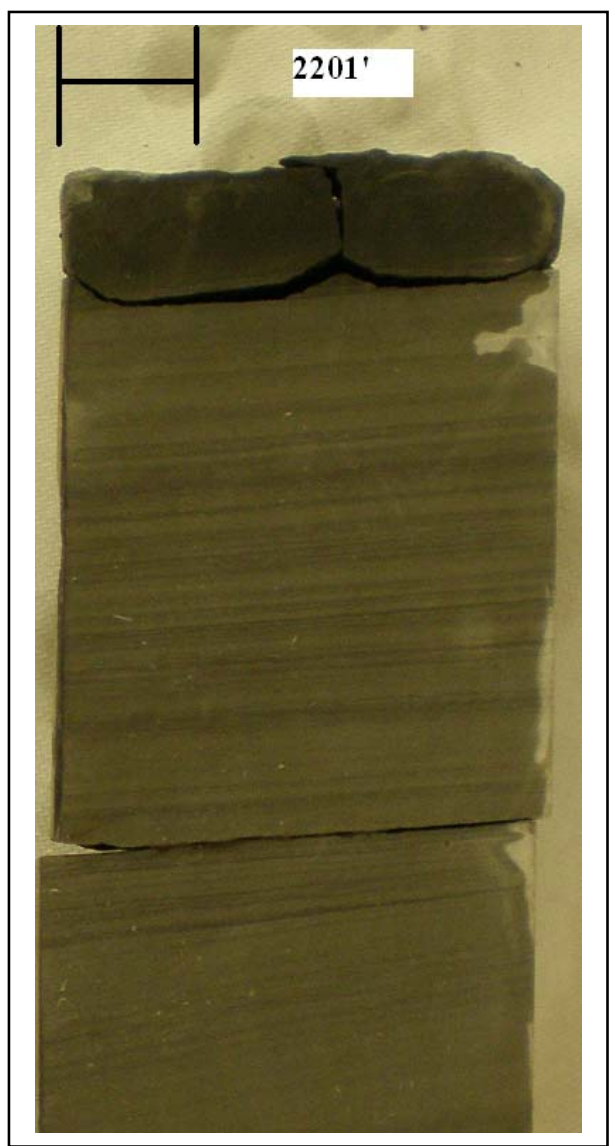

Figure 21: Vertical change from coarse siltstone (laminated, cross-laminated) to claystone (dark) at the contact between two packages of rock. Scale is one inch. 


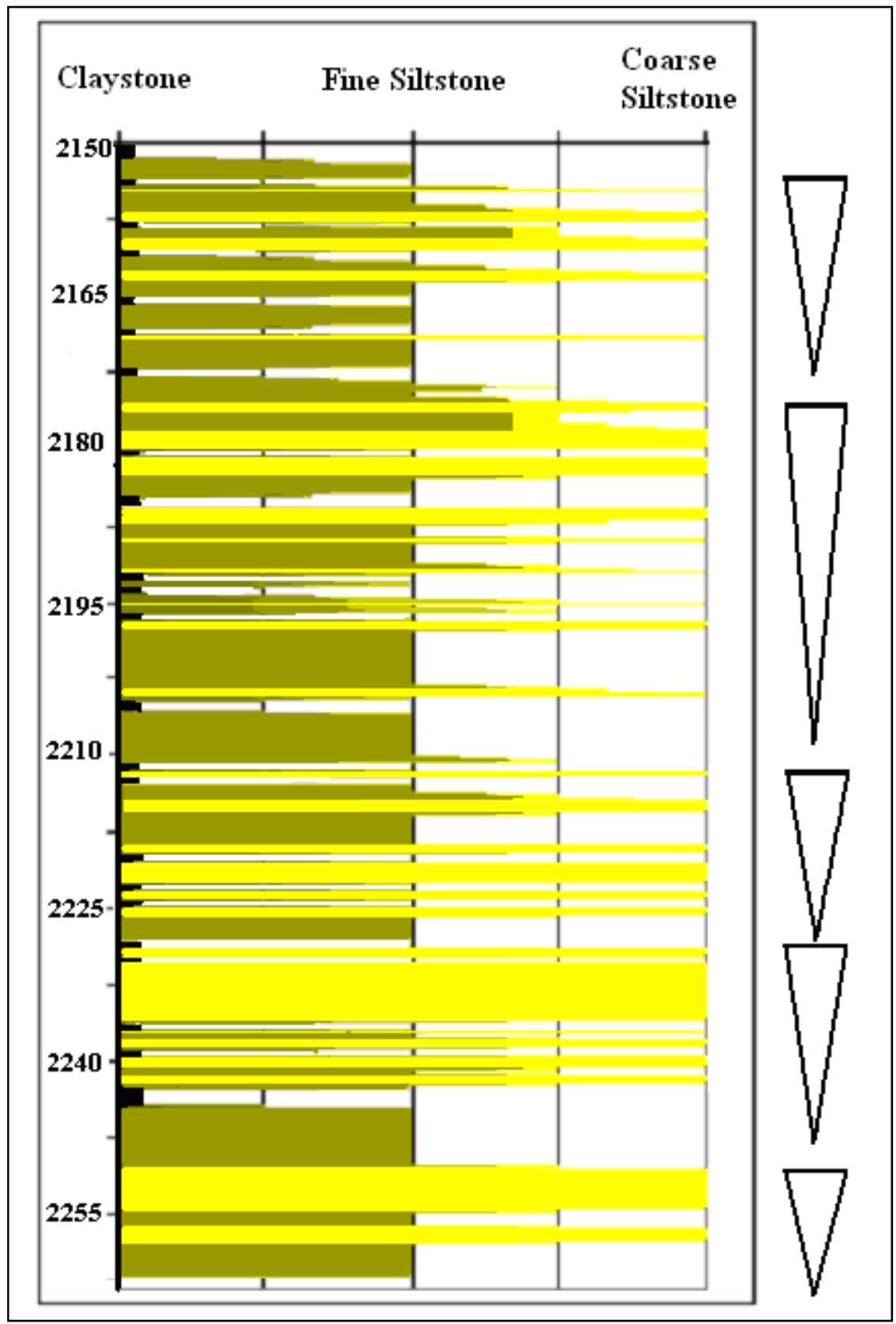

Figure 22: Depth distribution of three lithofacies identified from the FMI log. Triangles represent interpreted coarsening - upward parasequences.

The lithology over the approximately 110 foot section of the Lower Weir zone consists of rapid changes between coarse siltstone, fine siltstone and claystone.

Comparison of the core, the FMI log and thin sections from well \#4701705448 show that 
rapid changes occur within the unit between coarse siltstone, fine siltstone and claystone (Figure 23).

\begin{tabular}{|c|c|c|c|}
\hline \multicolumn{4}{|c|}{ Summary of the Weir Lithofacies } \\
\hline & Thickness & Structures & Fossils \\
\hline Claystone & $0.5-2 ’$ & $\begin{array}{l}\text { Soft sediment } \\
\text { deformation, horizontal } \\
\text { lamination }\end{array}$ & Plant debris, bioturbation \\
\hline $\begin{array}{l}\text { Fine } \\
\text { siltstone }\end{array}$ & $0.5-4^{\prime}$ & $\begin{array}{l}\text { Claystone partings, } \\
\text { cross-bedding, soft } \\
\text { sedimentary } \\
\text { deformation }\end{array}$ & $\begin{array}{l}\text { Bioturbation, vertical burrows, } \\
\text { shell debris, crinoid stems, } \\
\text { bivalves, brachiopods, plant } \\
\text { debris }\end{array}$ \\
\hline $\begin{array}{l}\text { Coarse } \\
\text { siltstone }\end{array}$ & $0.5-4^{\prime}$ & $\begin{array}{l}\text { Cross-bedding, partings } \\
\text { of claystone and fine } \\
\text { siltstone }\end{array}$ & Plant debris \\
\hline
\end{tabular}

Figure 23: Summary table of the Lower Weir lithofacies.

The claystone packages comprise the thinnest units throughout the zone. The range of thickness is normally less than half a foot and no greater than two feet. The thinner claystone packages often show signs of soft sediment deformation in the form of convolute bedding; in some cases both horizontal lamination and soft sediment deformation appear together (Figure 24). Fossils within these zones are limited to plant debris and bioturbation. Bioturbation was commonly present where fine siltstone and claystone are interbedded. 


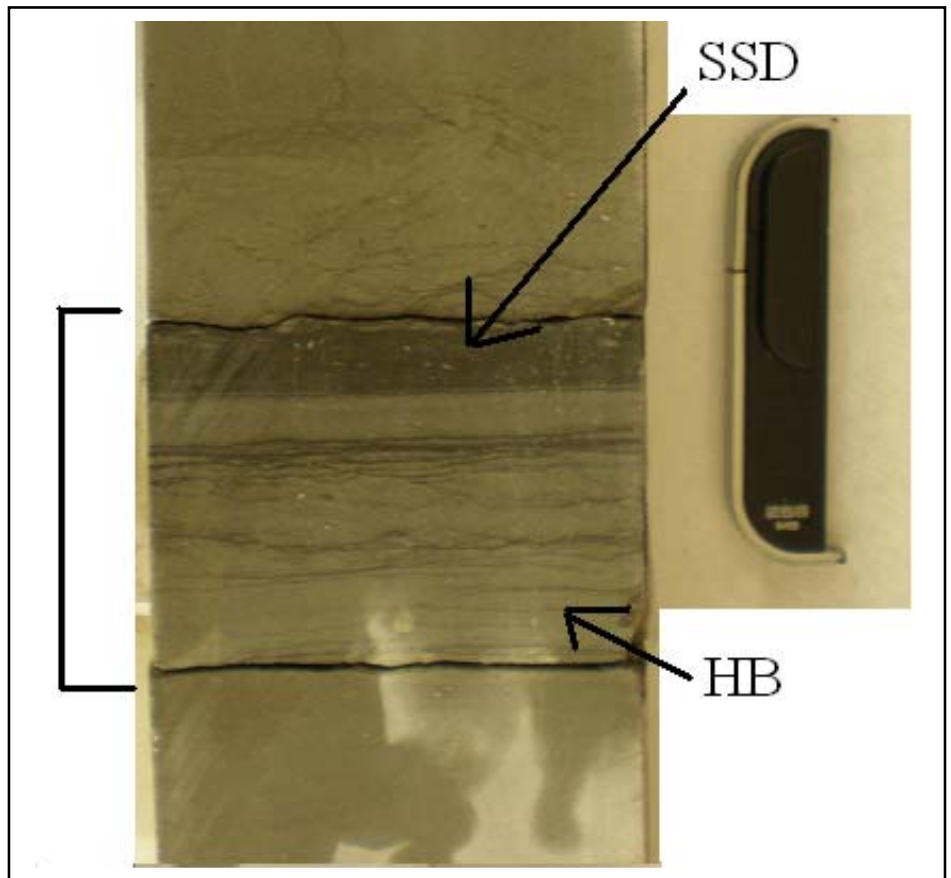

Figure 24: Claystone partings seen at 2212 (bracket) showing slight soft-sediment deformation (SSD) and horizontal bedding (HB). Memory stick for scale is 3.5 inches

Fine siltstone comprises a larger portion of the Lower Weir zone than claystone. The bed thickness ranges from less than half a foot to four feet thick. Larger sections of fine siltstone are commonly separated by thin claystone partings. Bioturbation is commonly seen throughout the fine siltstone portions of the Lower Weir zone (Figure 25). The fine siltstone also contains direct evidence of past life. Bivalve fragments (Figure 26), crinoid stems (Figure 27), and brachiopods (Figure 28) are seen within the Lower Weir from to 2183 to 2214 feet. Fine siltstone within this range generally contains abundant unidentifiable shell debris; however, the coarse siltstone beds do not have abundant recognizable fossil fragments. Some relatively large pieces of plant fragments were also found in the core (Figure 29). Small-scale cross-bedding was identified in several beds of fine siltstone; however they are generally infrequent in these beds. 


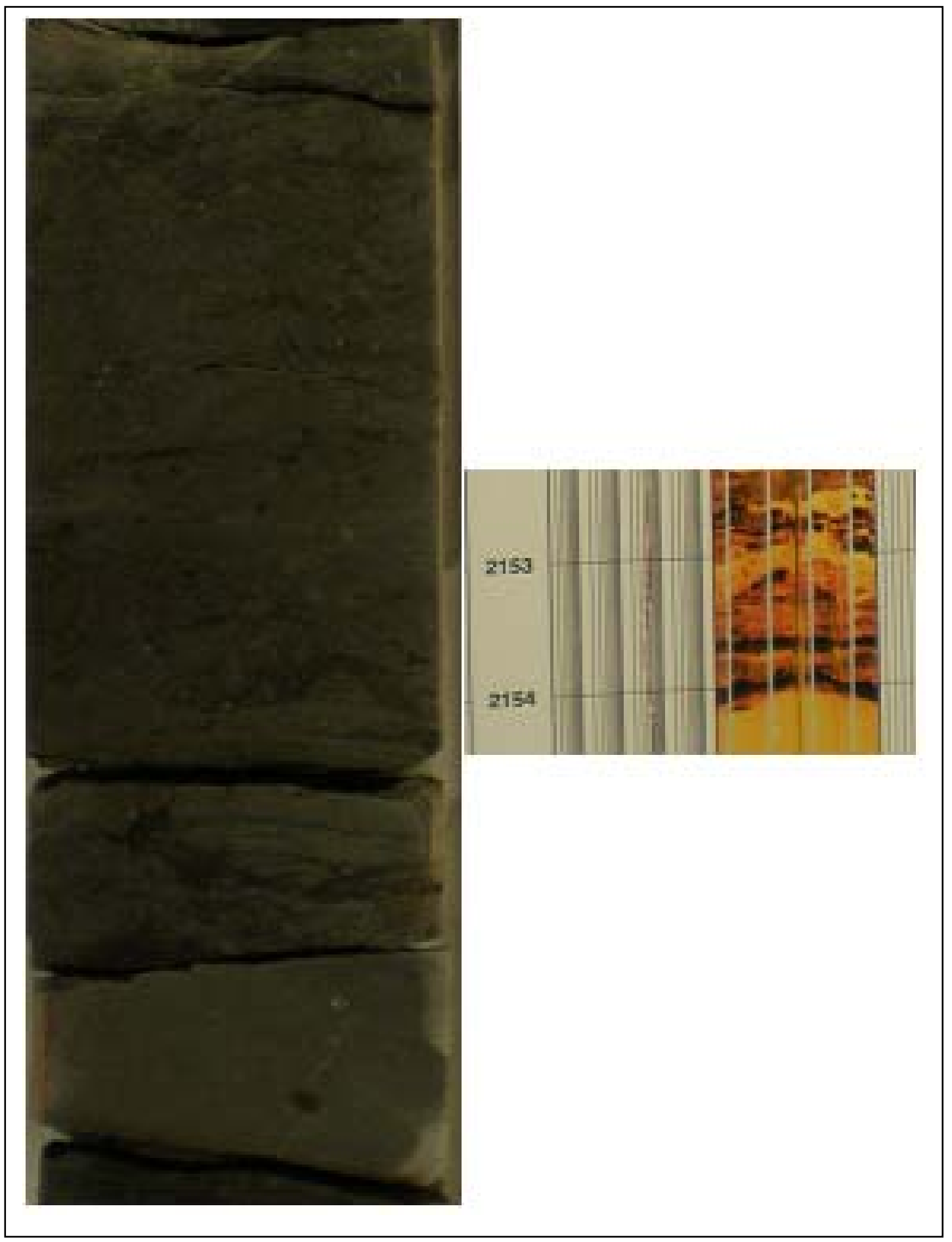

Figure 25: Fine siltstone bed that has been altered through bioturbation. Core is four inches wide. 


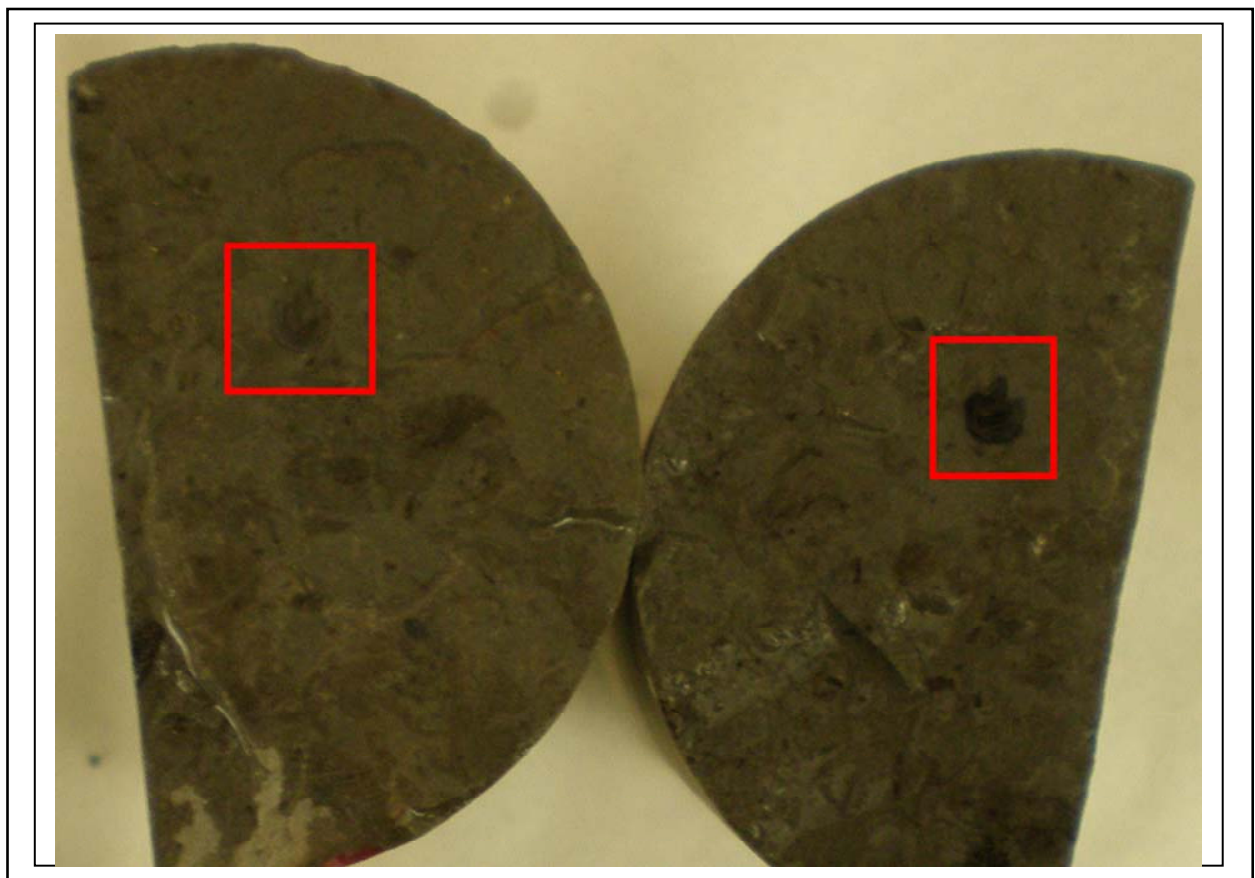

Figure 26: Shell fragment of a small bivalve highlighted in red at 2203 feet. Both part and counter part can be seen. Core is four inches in diameter.

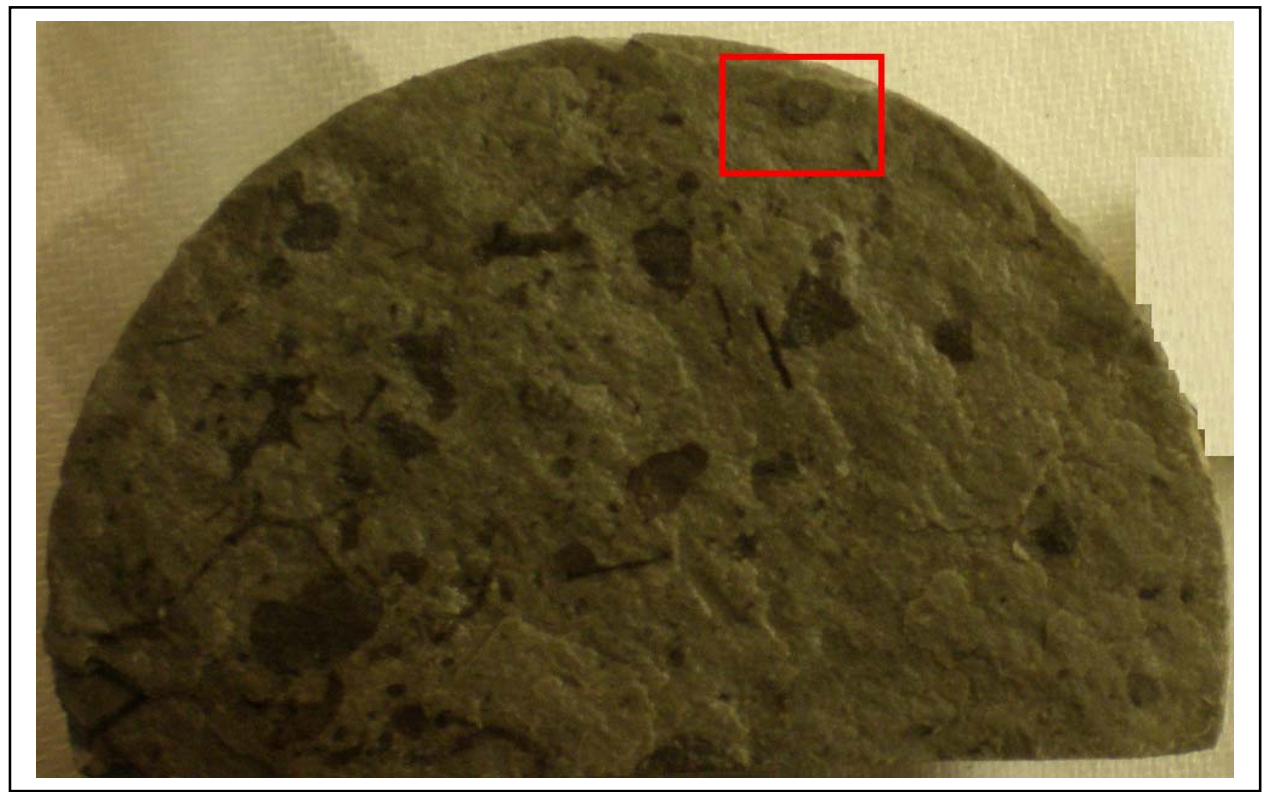

Figure 27: Crinoid stem highlighted in red at 2211 feet. Core is four inches in diameter. 


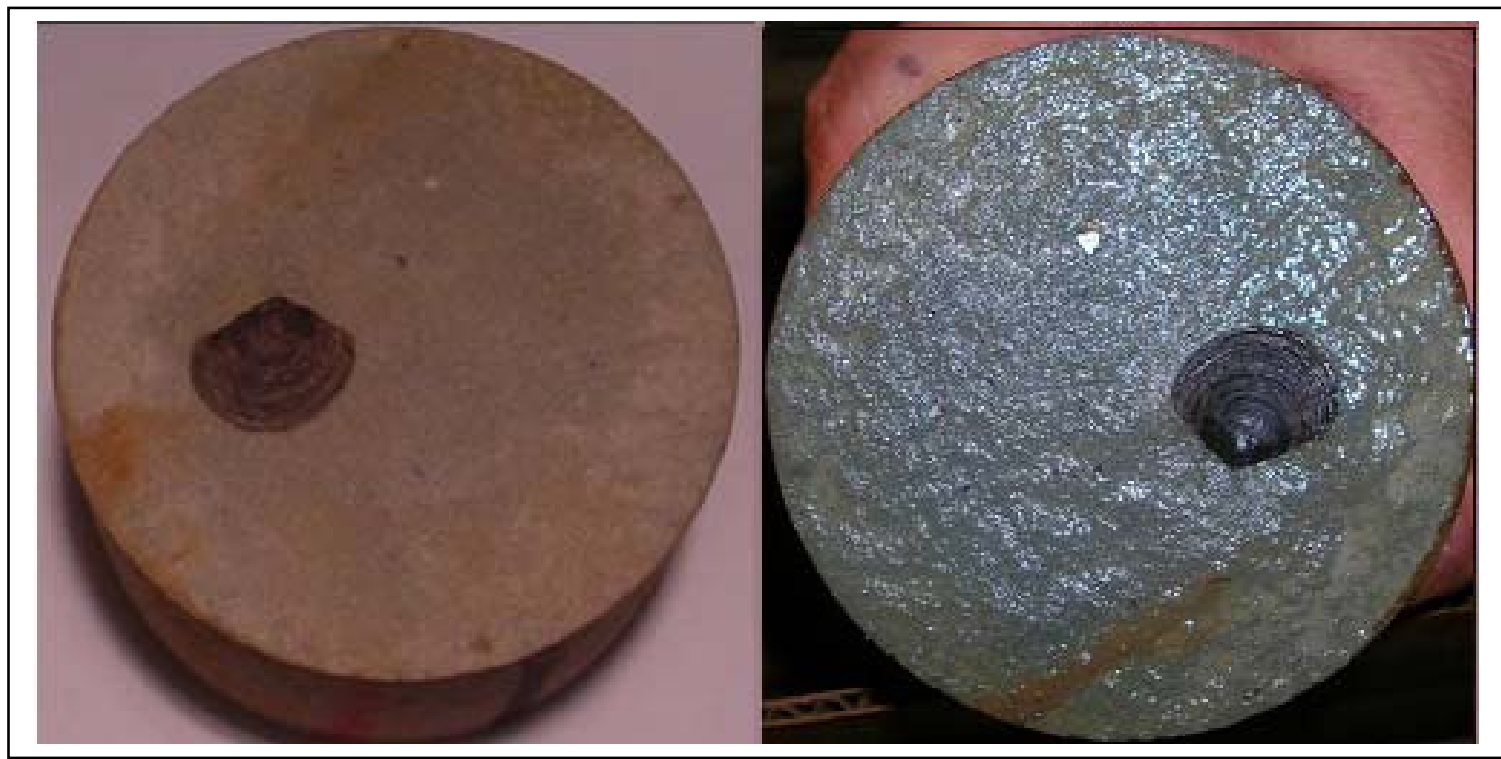

Figure 28: Mold (left) and original shell (right) of a single brachiopod at 2187 feet.

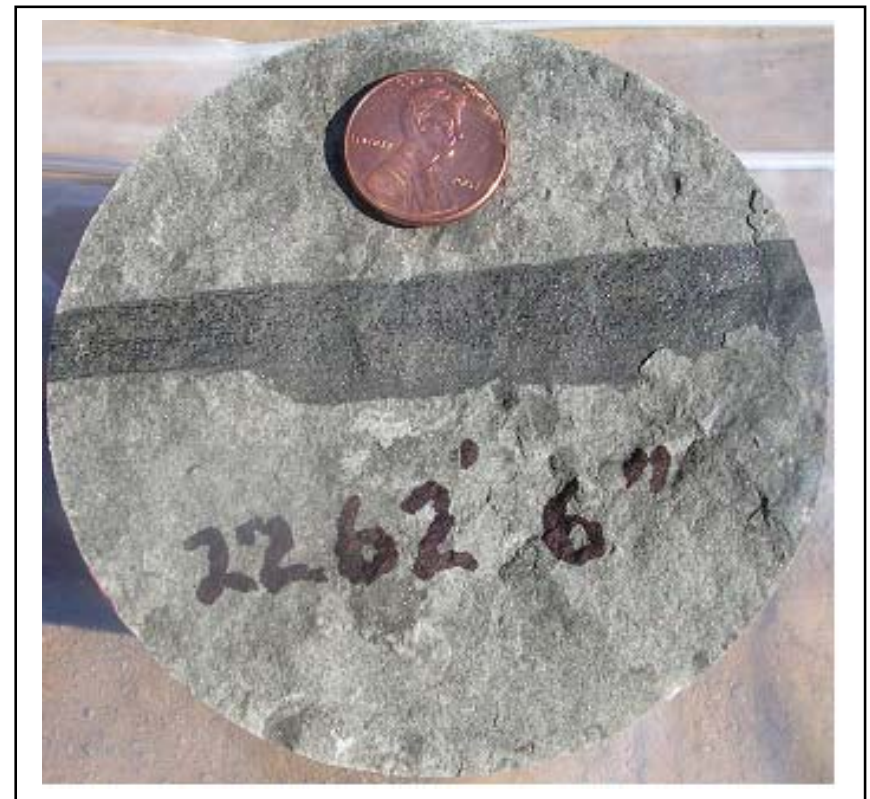

Figure 29: Signle large piece of plant material. The corrected depth of sample is 2244.6 feet. Sample is in fine siltstone.

The coarse siltstone ranges in thickness from less than half a foot to just over four feet. Though thick beds of coarse siltstone appear on the FMI log, they are commonly separated by thin beds of fine siltstone and claystone. Claystone partings are often 
deformed due to soft-sediment deformation. Small-scale cross-bedding is commonly seen throughout the coarse siltstone in the Weir zone on FMI and within the core (Figure $30)$.

Plant material is present throughout the Lower Weir core. The majority of this consists of small plant material which is numerous and contained in thin beds. Figure 31 shows several of these beds as they were identified in the core and on the FMI log in coarse siltstones of the Weir.

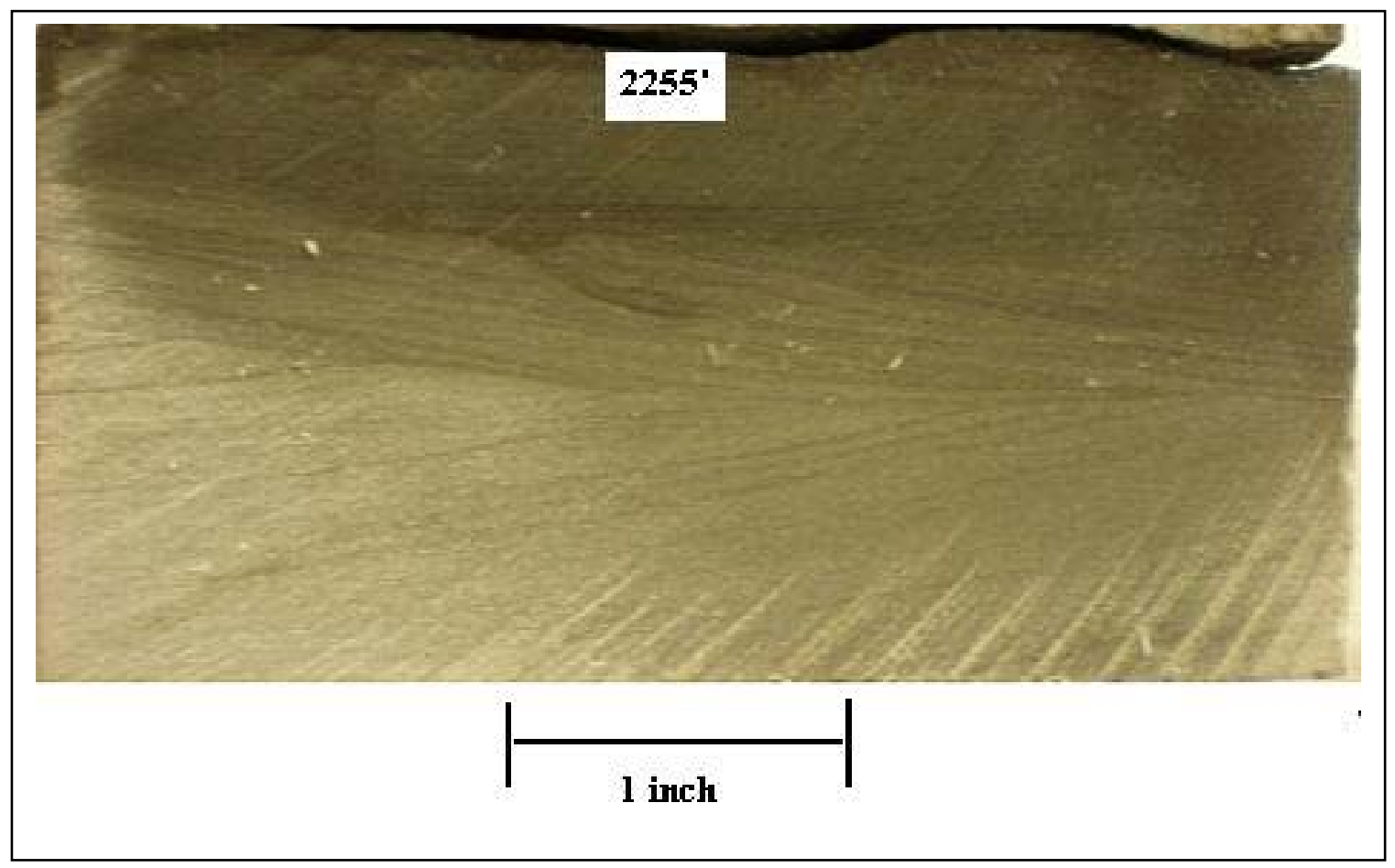

Figure 30: Small-scale cross-beds at 2255 feet within a fine siltstone package of the Lower Weir. 


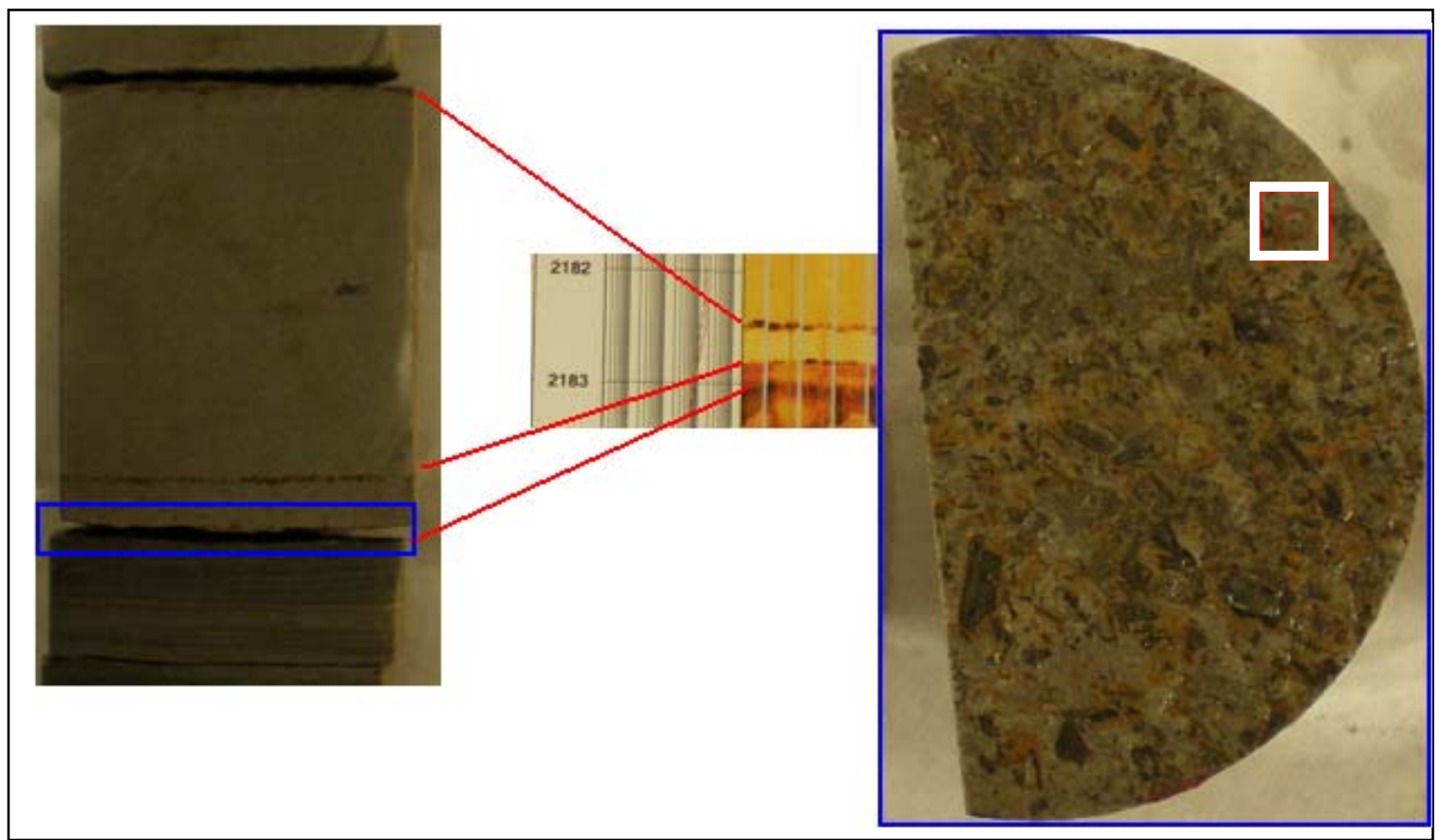

Figure 31: FMI response to thin layers of plant material. In addition to the small plant fragments (less than 1 inch), a crinoid (white box) stem is present. Each of the red lines connecting the FMI to the core represents a layer of plant material. The blue box around the vertical core indicates where the bedding-plane picture is located. These beddingplanes appear in coarse siltstone. Core is four inches in diameter.

Trace fossils are present within the Lower Weir zone in addition to bioturbation.

Vertical burrows that are connected by a horizontal passage similar to that of

Diplocraterion (Figure 32) occur at 2249 within a fine siltstone portion of the unit.

Diplocraterion are interpreted as the burrows left behind by an organism, the connecting horizontal passages represent adjustments by the burrower to correspond to shifts in the sediment overhead (Prothero, 1998). Diplocraterion is commonly found in the Glossifungites ichnofacies. Glossifungites represents firm substrates that have yet to be lithified (Prothero, 1998). 


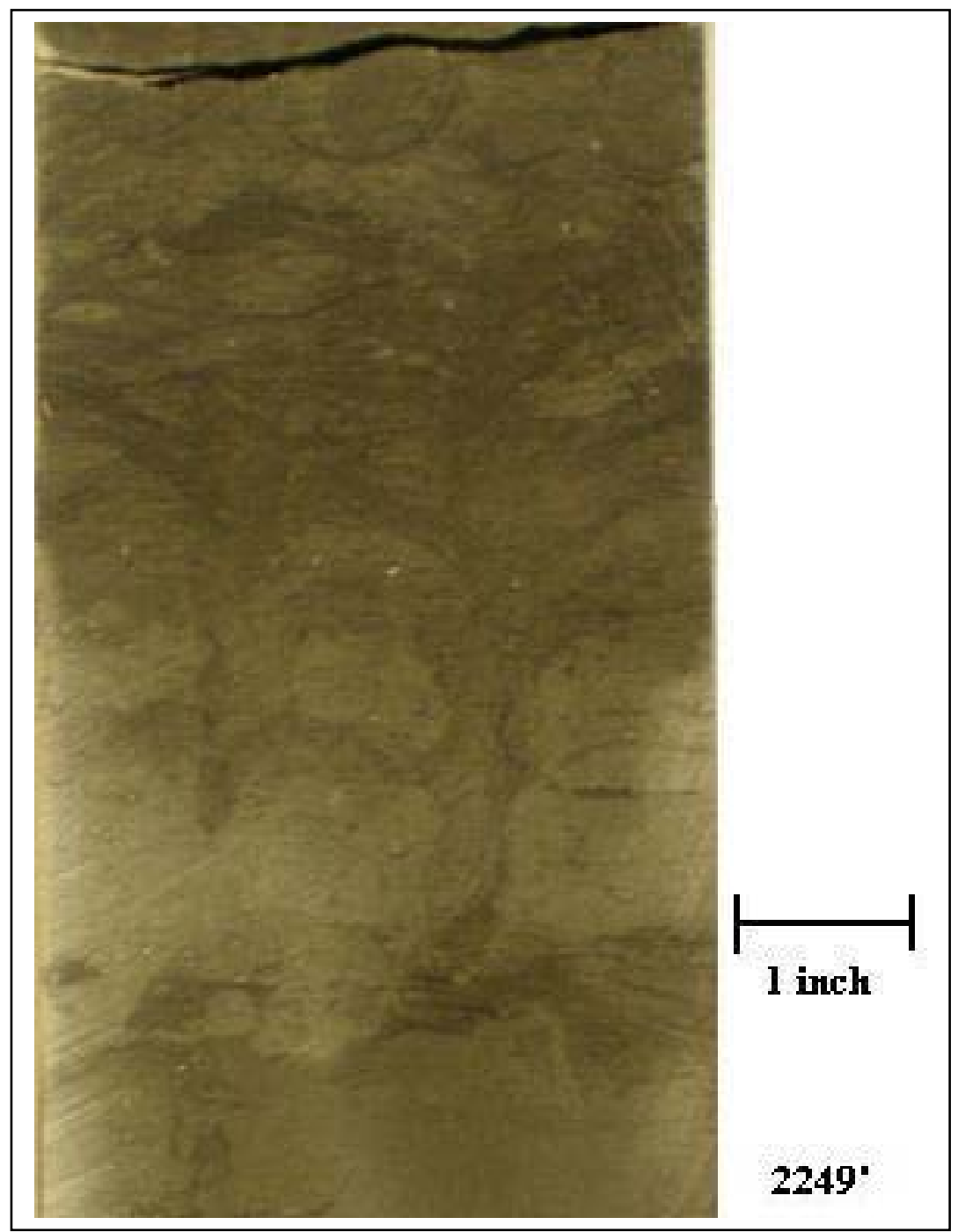

Figure 32: Vertical burrows are seen here just above 2249 feet in the core.

Inspection of the gamma-ray log of the Lower Weir beds shows a gradual trend of fining-upward texture. This trend is easily seen using the GeoColumn shading option in PETRA (Figure 33) and on the gamma-ray curve of well \#4701701864 (Figure 34). This trend is caused by an increase in fine siltstone/claystone interbeds as seen on FMI log (Figure 22). The fining-upward trend continues into the unnamed shale above the Lower Weir and is recognized by a continually increasing gamma-ray value. However, within 
the overall fining-upward pattern, packages of coarsening upward sediment are present.

These packages are recognized in Figure 22.

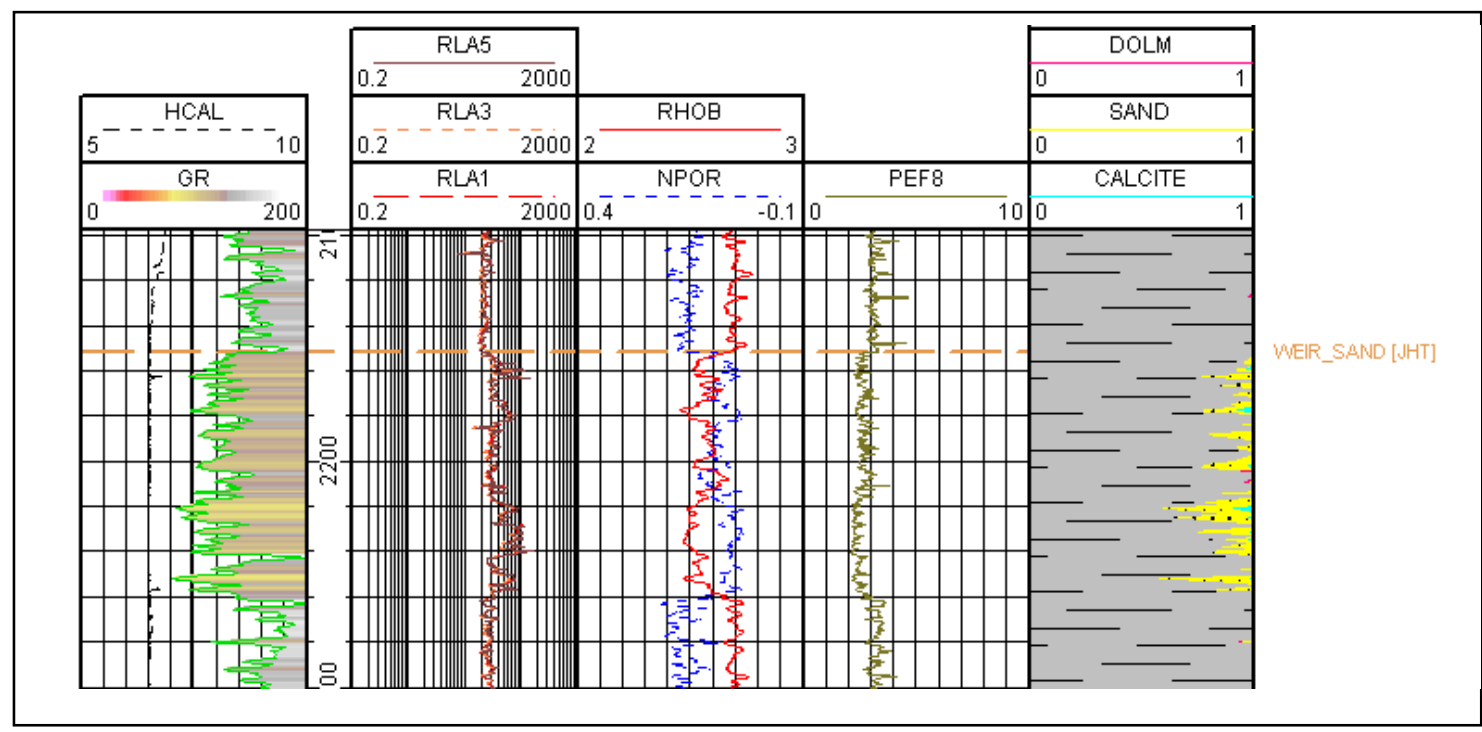

Figure 33: Log plot for well \#4701705448. The gamma-ray curve on the left track is shaded gradually to show change in the Lower Weir beds. 


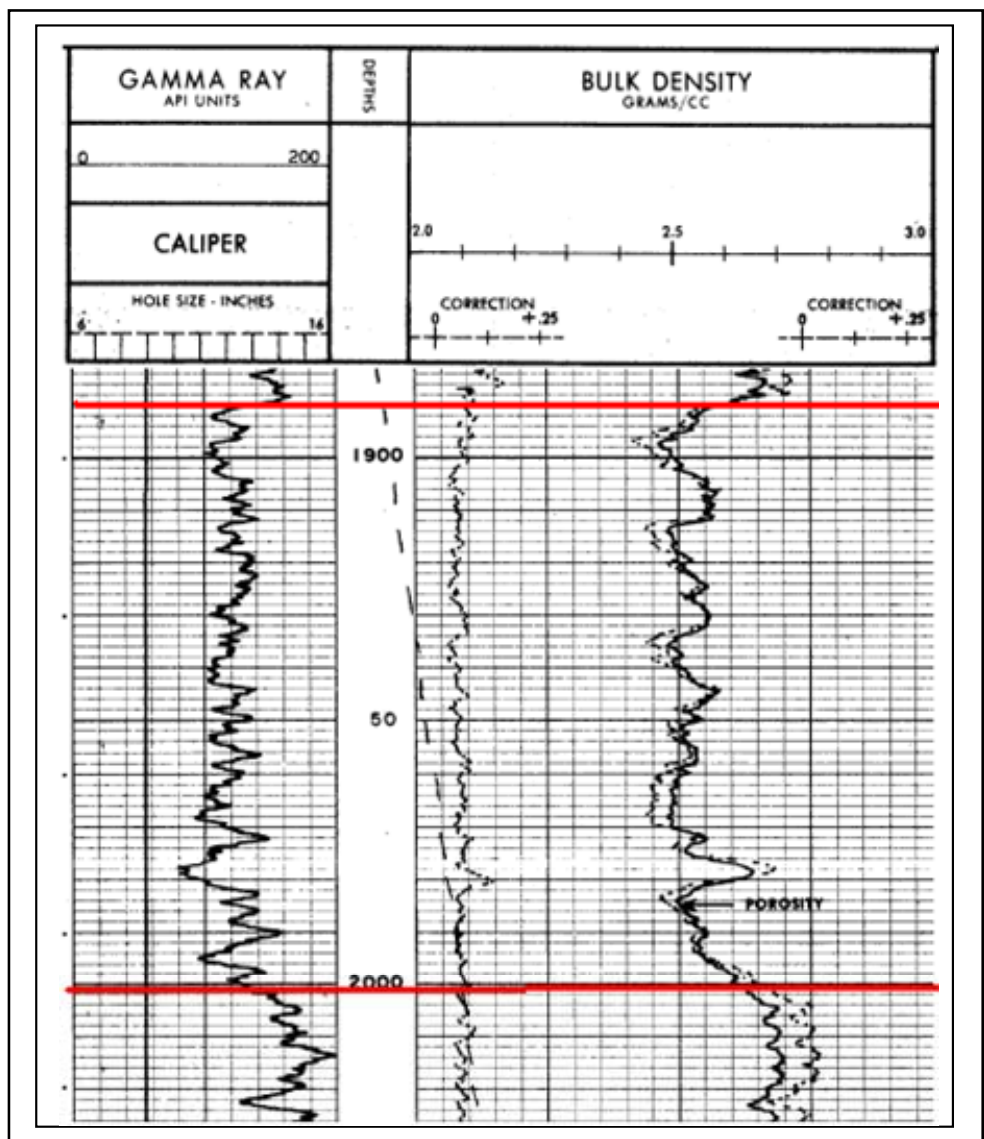

Figure 34: Log response of the Lower Weir zone within well \#4701701864

\section{Thickness}

Once the Lower Weir was identified and correlated across the study area, several maps could be constructed. An isopach map of the Lower Weir beds (Figure 35) was generated which confirmed the relative north-south trend described by Zou (1993). Contrary to Zou, the Lower Weir reaches a maximum thickness of over 130 feet along the western side of the study area in Doddridge County. The thickest portion of the Lower Weir ranges between 110 to over 130 feet. The north-south thick is 3.8 miles wide in the West Union quadrangle and 4.7 miles wide in Oxford quadrangle, and it has an orientation of $\mathrm{N} 346^{\circ}$ in the western portion of the study area. The thickness gradually decreases to the east where the Lower Weir beds are less than 75 feet thick. 


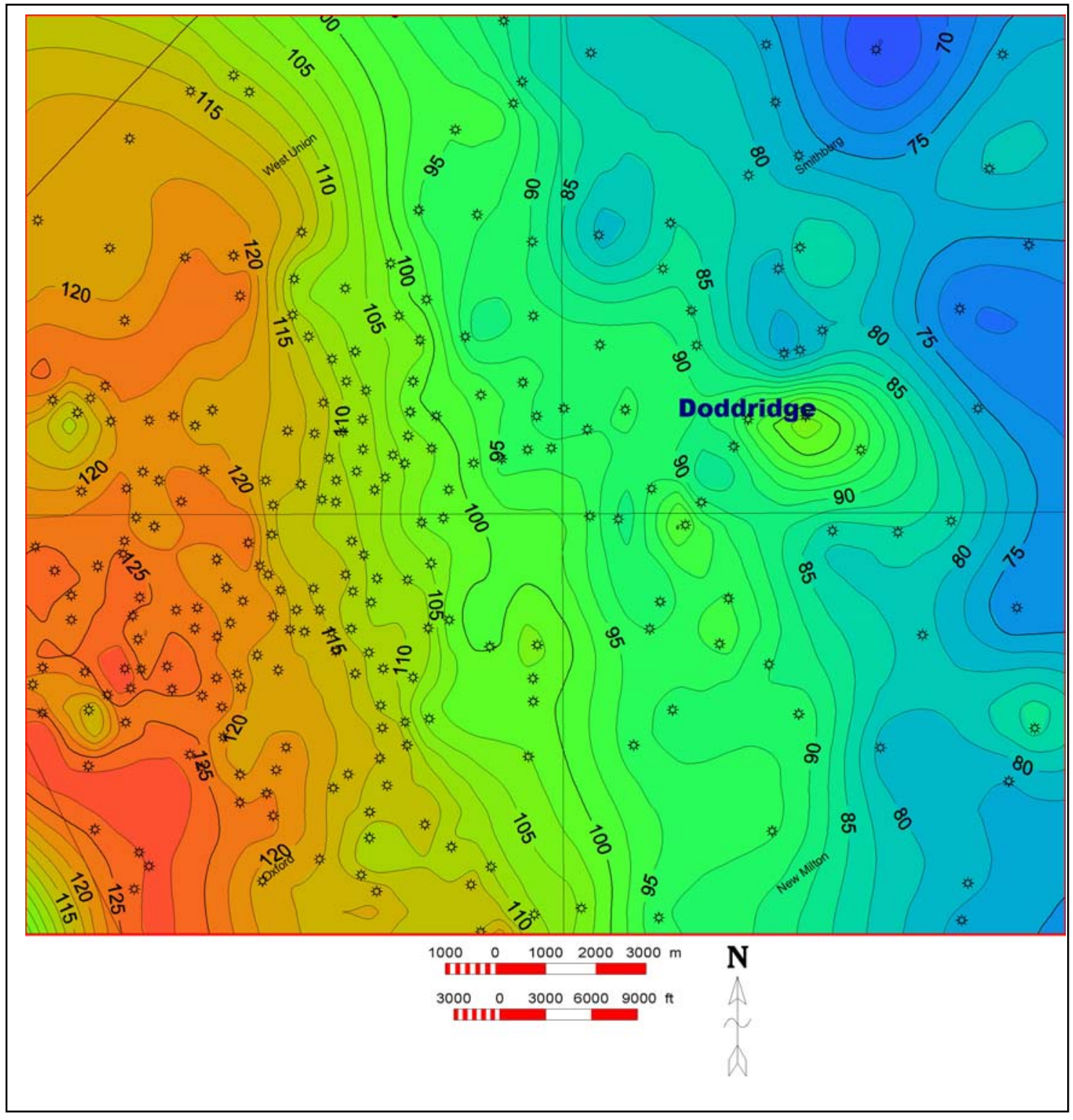

Figure 35: Isopach map of the Lower Weir beds. The thickness of this unit ranges from 127.5 feet in the west to 60 feet in the east. Contour interval of 2.5 feet.

Figure 36 illustrates the percent of the siltstone in the Weir zone with porosity greater than $6 \%$. This map indicates that the siltstone depocenter is just to the east of where the Lower Weir beds reach their maximum thickness as seen in Figure 35. In the central portion of Oxford and West Union quadrangles, a distinct trend in which porous siltstone represents $90-95 \%$ of the Lower Weir thickness is identified. This trend is 1.5 to 
3.7 miles wide. Small tongues of the Lower Weir extend out from this trend for short distances to the east and west. For example, there is a major dip-oriented trend reaching toward the WSW in the southwest corner of the study area. 


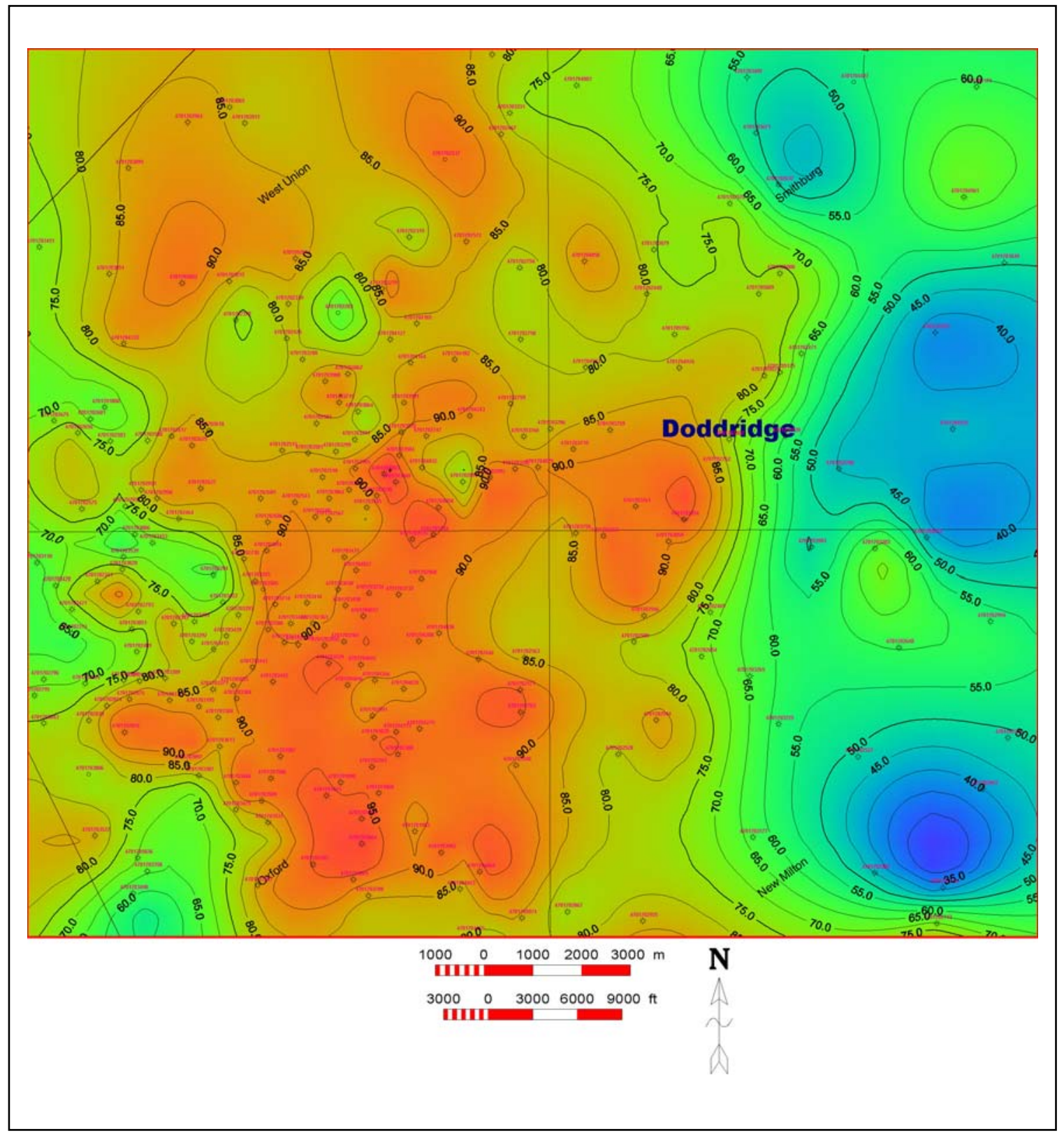

Figure 36: Siltstone percent map of the Lower Weir. Values range from $95 \%$ (red) to 30\% (blue). 


\section{Depositional Environment}

Factors influencing depositional environment were interpreted through the analysis of core from well \#4701705448 and through patterns and changes examined on well logs.

Seven cross sections were generated in order to illustrate changes that occur within the Lower Weir beds across the study area. Three cross sections extend from west to east and show the changes that occur in the Lower Weir along regional dip. Four cross sections extend from north to south and show the changes that occur to the Lower Weir along strike. These cross sections contain tif images of well logs, and given the quality of these logs, making interpretation on them was difficult. Converting the tif images to digital data enhanced the display. Figure 37 shows the central dip cross section through the study area. Figure 38 shows the southern dip cross section. Interpretations were made based on correlation of peaks on the gamma-ray curve that are representative of coarse siltstone. The sizes of these packages range in thickness from 4 feet to 14 feet and extend for 3 miles to 11 miles across the study area. Whereas some packages do seem to correlate, the vast majority of these siltstones pinch out laterally. The difficulty in mapping these packages can be attributed to the shifting patterns of sedimentation during Weir deposition.

Small-scale cross-beds were identified within the core of well \#4701705448 and on the FMI log (Figure 39 and 40). These cross-beds, no thicker than 6 inches, formed as ripple marks in a low - energy environment. Small-scale cross-bedding was identified between 2231 and 2230 feet with a dip of 7-10 degrees and an azimuth to the east. Ripple cross-bedding was also identified at 2223, between 2220 and 2221.5, and at 2218.5. 


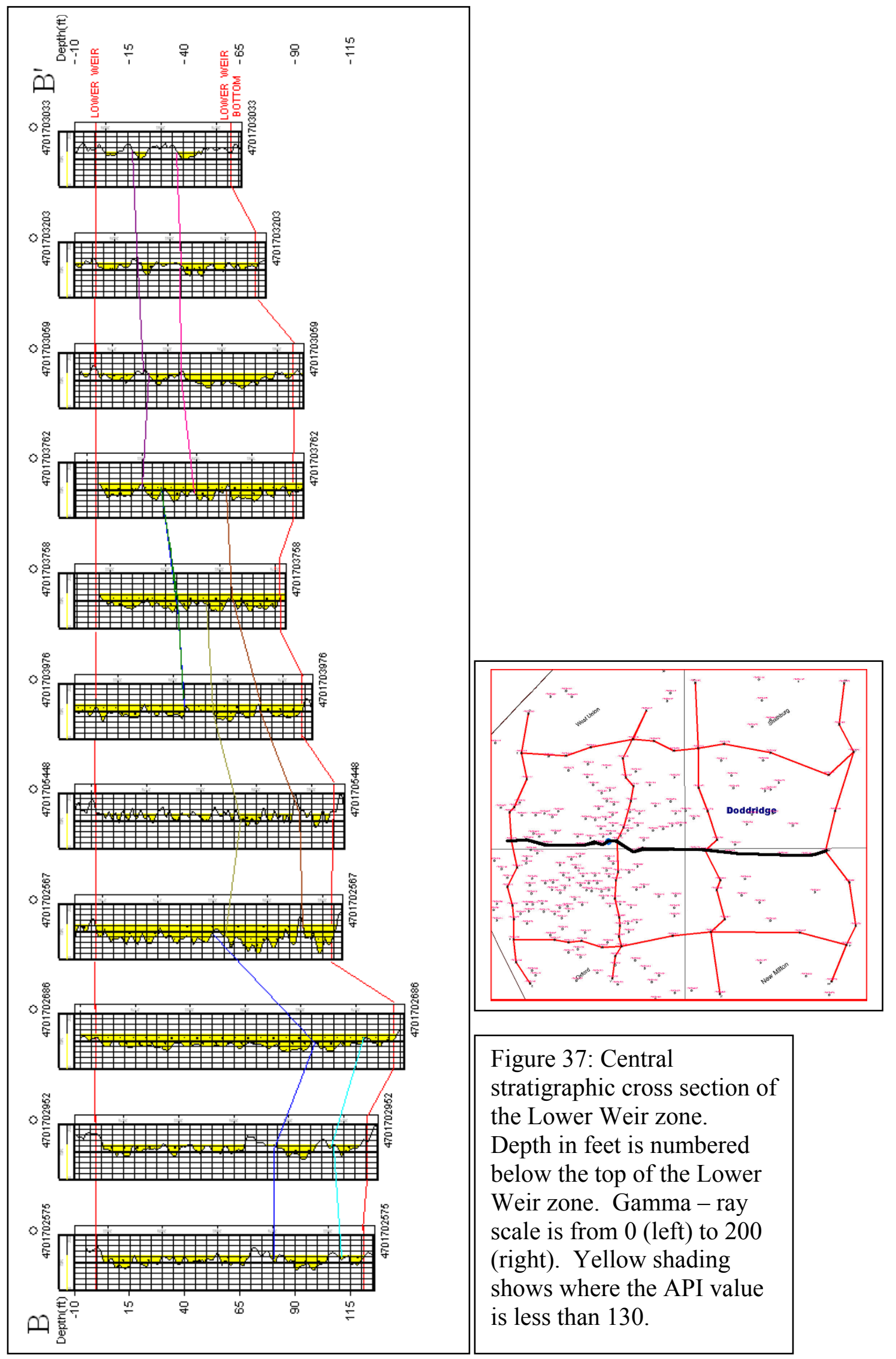



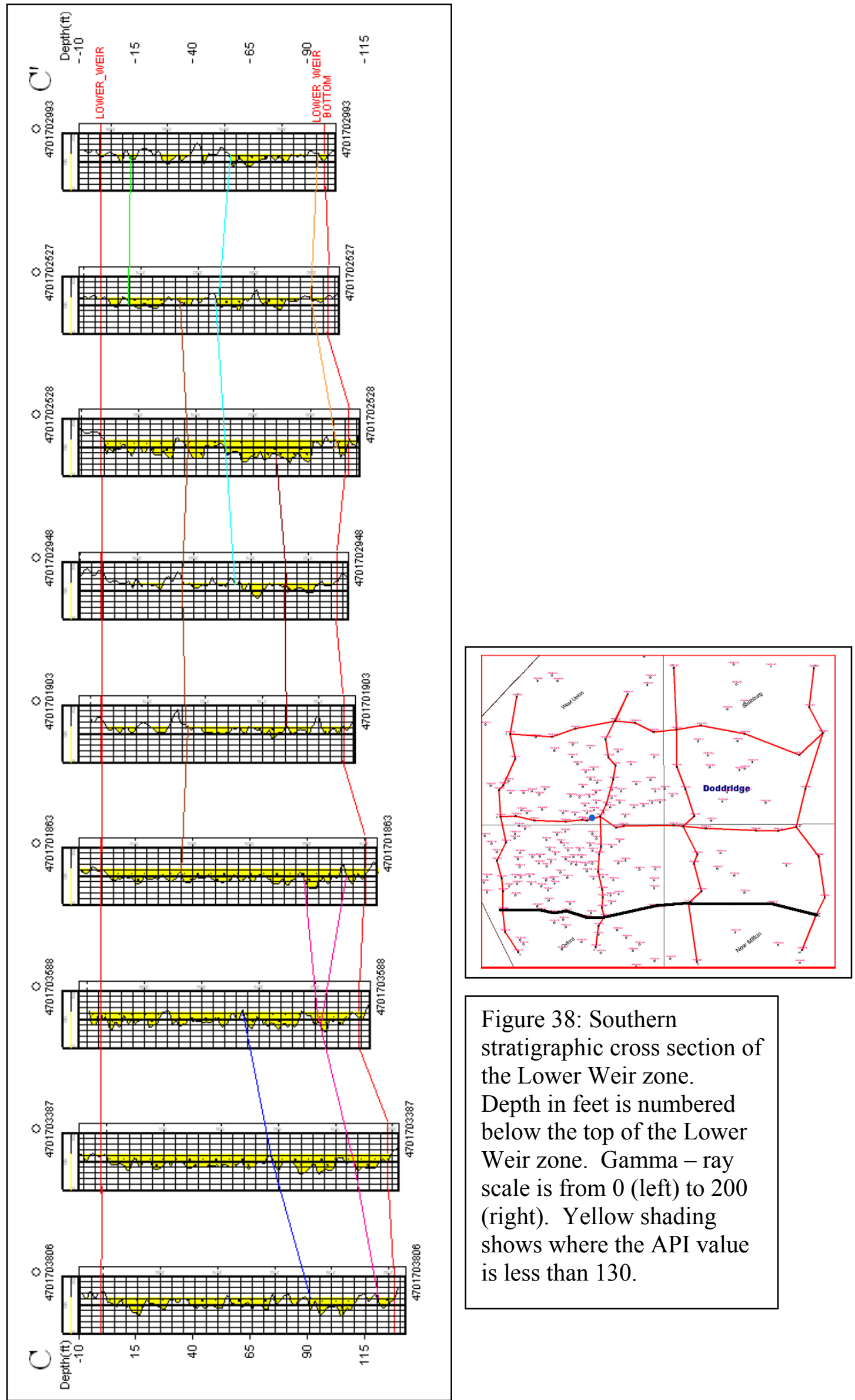

Figure 38: Southern stratigraphic cross section of the Lower Weir zone. Depth in feet is numbered below the top of the Lower Weir zone. Gamma - ray scale is from 0 (left) to 200 (right). Yellow shading shows where the API value is less than 130 . 


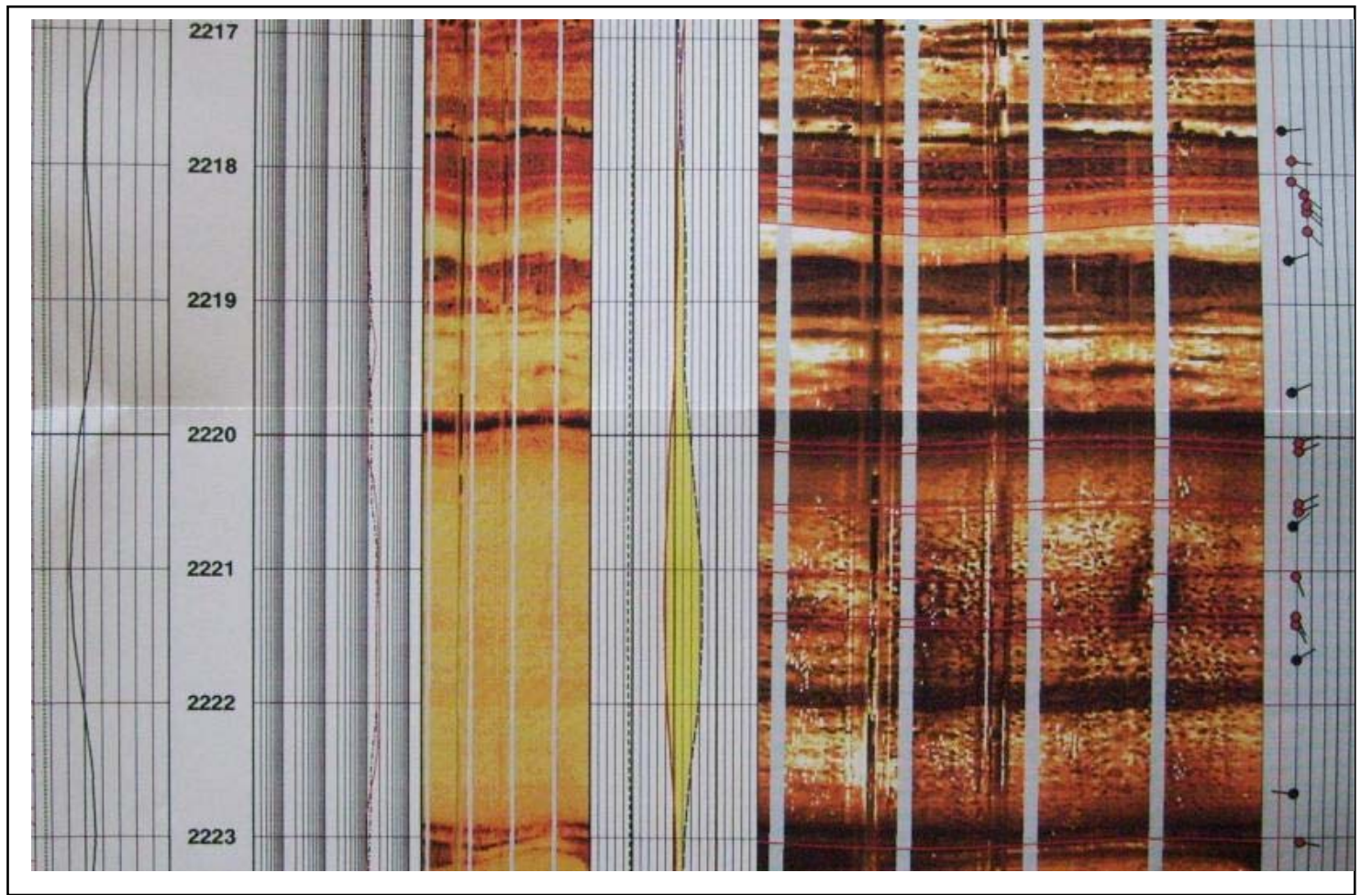

Figure 39: FMI log for well \# 4701705448. Cross-bedding has been identified within this section of the log by the red horizontal lines passing through the FMI image on the right. The far right track contains the dipmeter readings for these cross beds (red) and the overall formation (black).

These cross-beds also dip at 5-10 degrees with an east orientation (Figure 39). Crossbedding becomes less frequent higher in the section, but cross-beds were identified at 2203.75 having an azimuth towards the west and a dip of 13 degrees, and at 2205.75 with an azimuth towards the southeast and dip of 17 degrees. A series of cross-beds were identified between 2177.5 and 2179.25 feet with an azimuth to the north and dipping between 7-25 degrees. Two cross-beds occur between 2167 and 2168 with a dip of 10 degrees and an azimuth to the south. A final cross-bed was identified at the top of the Lower Weir beds at 2153.25 with a dip of 24 degrees and an azimuth towards the northwest. All dips were plotted on a rose diagram and show a predominate trend to ESE 
(Figure 40). This trend indicates the direction of the prevailing current during the time of deposition. This direction would be approximately perpendicular to the regional shoreline (Boswell, 1988).

\section{Dip Direction}

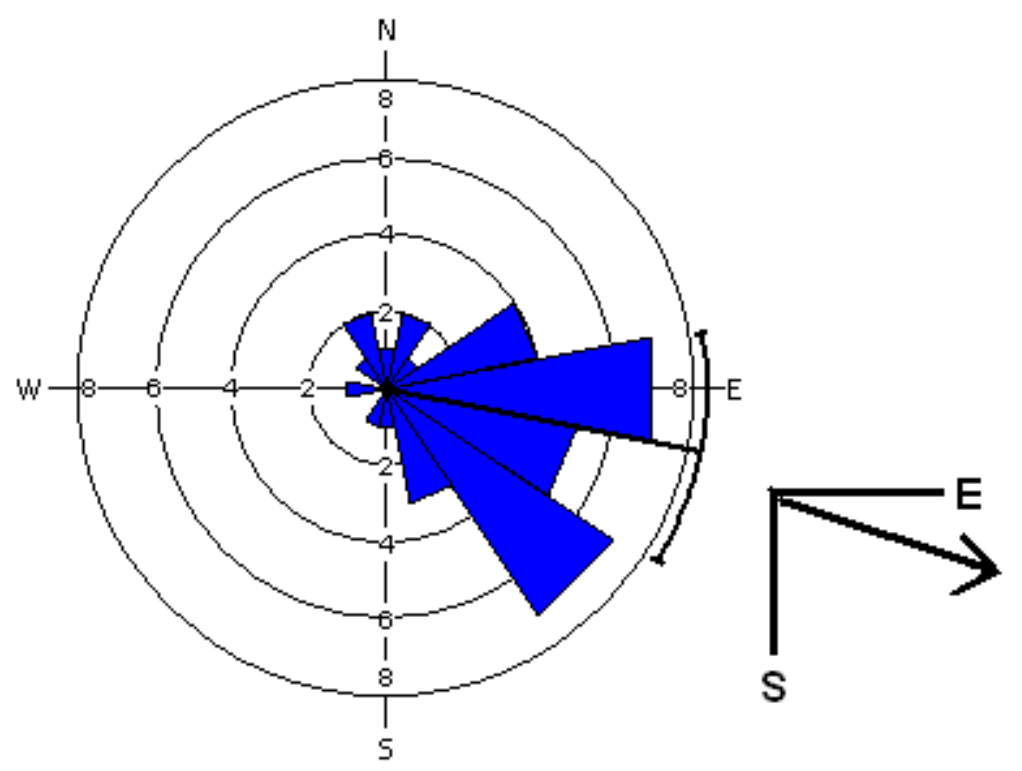

Figure 40: Rose Diagram of the cross-bed dips as recorded on a dipmeter on the FMI log. Mean vector of $101^{\circ}$. The number of data points $(\mathrm{N})$ is 35 .

My interpretation is as follows (Figure 41). The Lower Weir beds of Doddridge County were deposited in an offshore marine environment of normal salinity, as indicated by the presence of crinoids, brachiopods and bivalves. Terrigenous sediment was introduced to the sea by way of a delta situated approximately $100 \mathrm{~km}$ to the east in eastern West Virginia and Maryland (Bjerstedt, 1986; Bjerstedt and Kammer, 1988; Boswell, 1988). Sand accumulated on the inner shelf relatively close to the shoreline. Fine and coarse mud and fine plant material, on the other hand, would have been carried 
seaward by surface-sediment plumes emanating from the river's mouth and by stormgenerated bottom currents (compare with Reading 1995; Pratson et al. 2007). Mud then settled from suspension in deep, quiet water beneath wave base on the outer shelf. This mud was often reworked by shoaling internal waves which winnowed the clay and produced anomalously coarse zones of silt on the deep sea floor (compare with Sommerfield et al. 2007; Pratson et al. 2007). Internal waves were triggered by activities of ocean currents, tides, and storms and propagated along density interfaces (pycnocline) within the water column. They were reflected shoreward (ESE) across the low gradient of the shelf. Shoaling waves generated bottom flows that resuspended the clay and redistributed the silt shoreward (as indicated by the orientation of small-scale cross-beds and large lobes extending towards the east) (Figure 41). Lobes of sediment extending westward from the main siltstone body may reflect areas of mass movement down the steeper slope. The north-south trend of the Weir probably follows the general contour on the shelf where internal waves shoaled and winnowed muds. The large amount of accommodation space required to produce the Weir beds (more than 100 feet thick) was generated by eustatic sea-level rise, or basin subsidence and the compaction of underlying muds and sediment loading. 


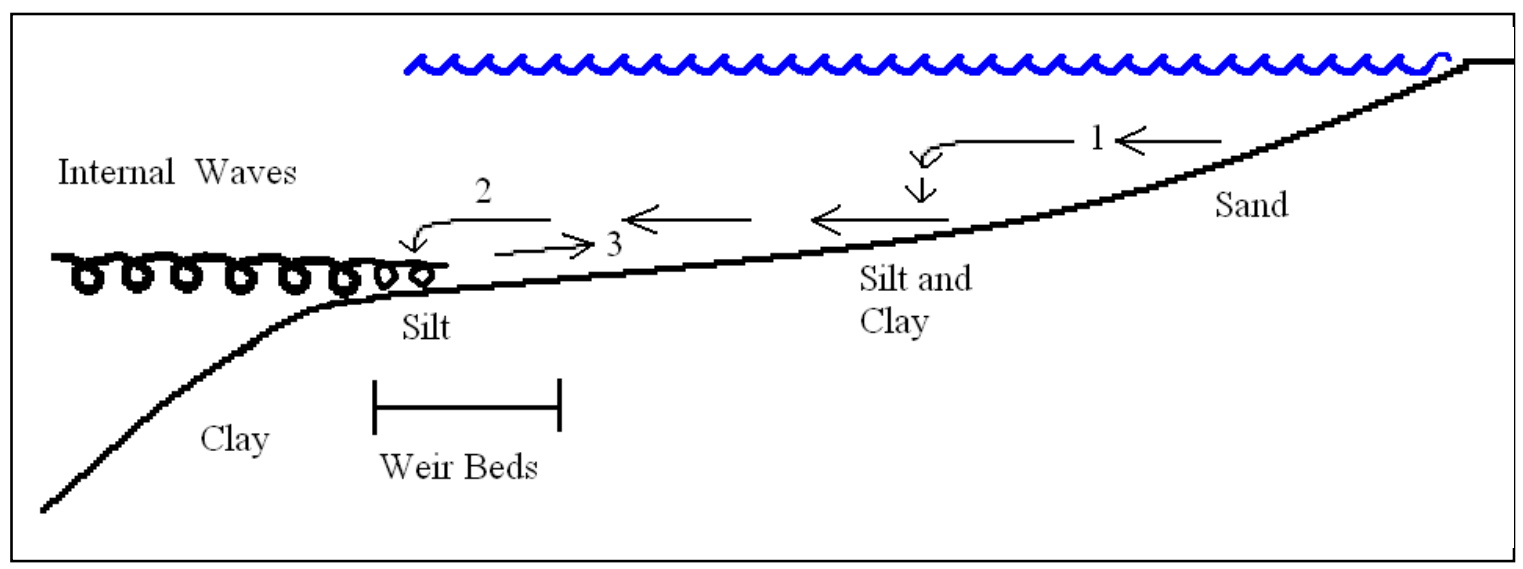

Figure 41: Pictorial representation of internal waves. 1 represents the surface - sediment plume, 2 represents offshore sediment transport, and 3 represents the remobilization of silt.

Figure 42 is a paleogeographic map showing my interpretation of the Weir deposition in Doddridge County. The small lobes of silt extending seaward were generated by mass movement of sediment towards the basin center and the lobes extending landward represent those generated by sediment moved landward from internal waves. Overall the fining upward sequence reflects the establishment and growth of the eastern delta, the consequent trapping of a coarser sediment on the inner shelf, and a reduction of silt delivered to the outer shelf. Interbedding of silt and clay reflect fluctuations in energy level of the interval waves and shear stress exerted on bottom sediment and/or fluctuations in position of the density interface (and perhaps sea level). 


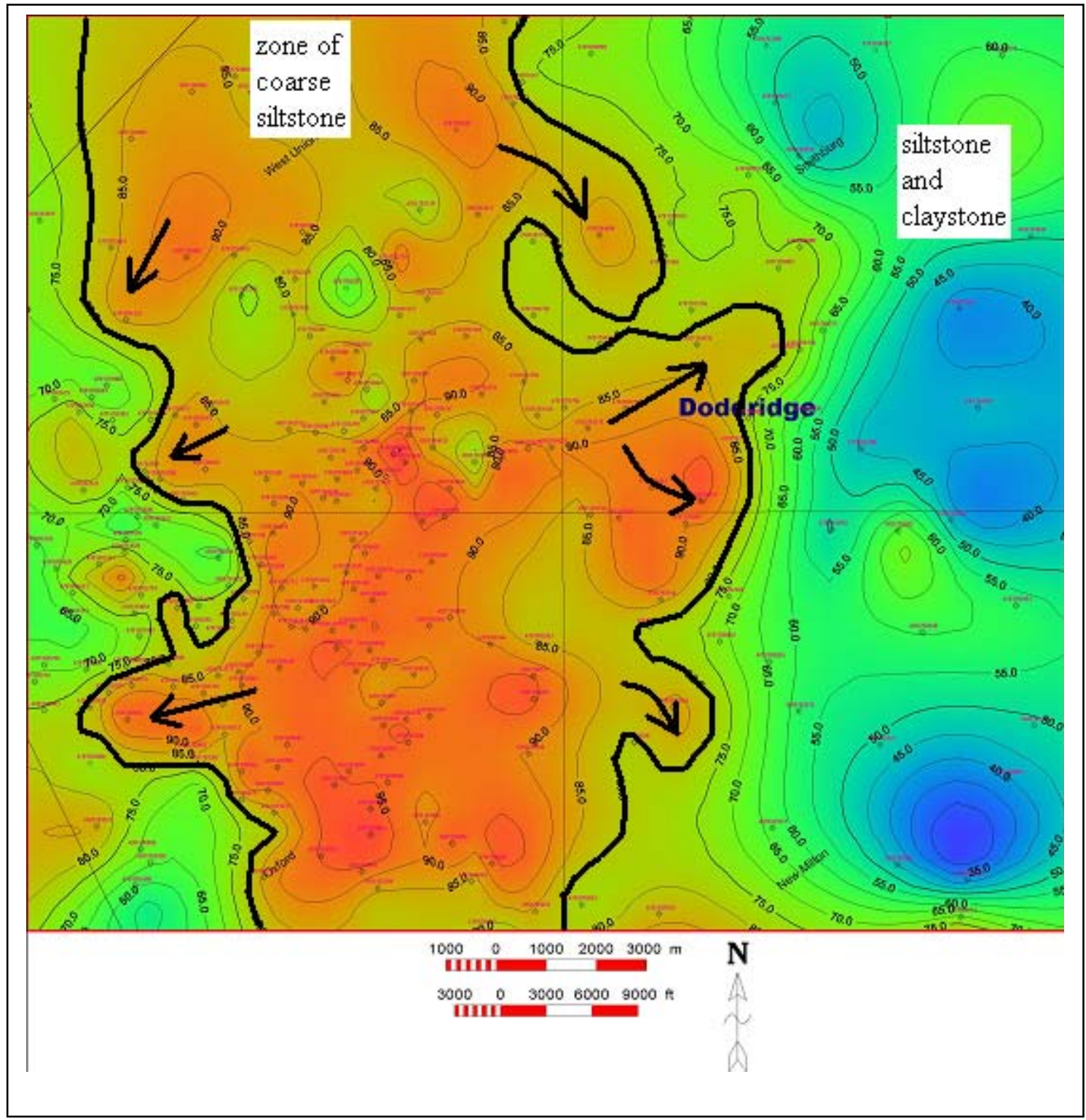

Figure 42: Paleogeography map of the Lower Weir zone superimposed on the siltstone percent map of the Lower Weir (Figure 36). Arrows to the west indicate possible zones of mass movement, and arrows to the east indicate locations of possible spill-over lobes. 


\section{Porosity}

The net-pay map of the Lower Weir generated at $6 \%$ porosity (Figure 43 ) resembles in general the isopach of the Lower Weir (Figure 35). At this cut-off value, the map becomes useful for natural-gas exploration in that it narrows the prospect area to Oxford and West Union quadrangles in the west. The isopach map generated for the Lower Weir beds (Figure 35) shows that the thickest portion is along the western border of the study area. The net-pay map, though, shows that the thickest portion of higherporosity siltstone is more toward the center of the Oxford and West Union quadrangles. A net - pay map generated at $8 \%$ porosity identifies areas of greatest potential in the Lower Weir (Figure 44). This map also shows some variation between the northwestern and southwestern portions area. The greatest thickness occurs in the southwest along the axis of the Arches Fork anticline. Where structure and porosity coincide marks the optimum area for testing the Lower Weir beds for natural-gas production. Permeability and porosity will be discussed in more detail later in the results. 


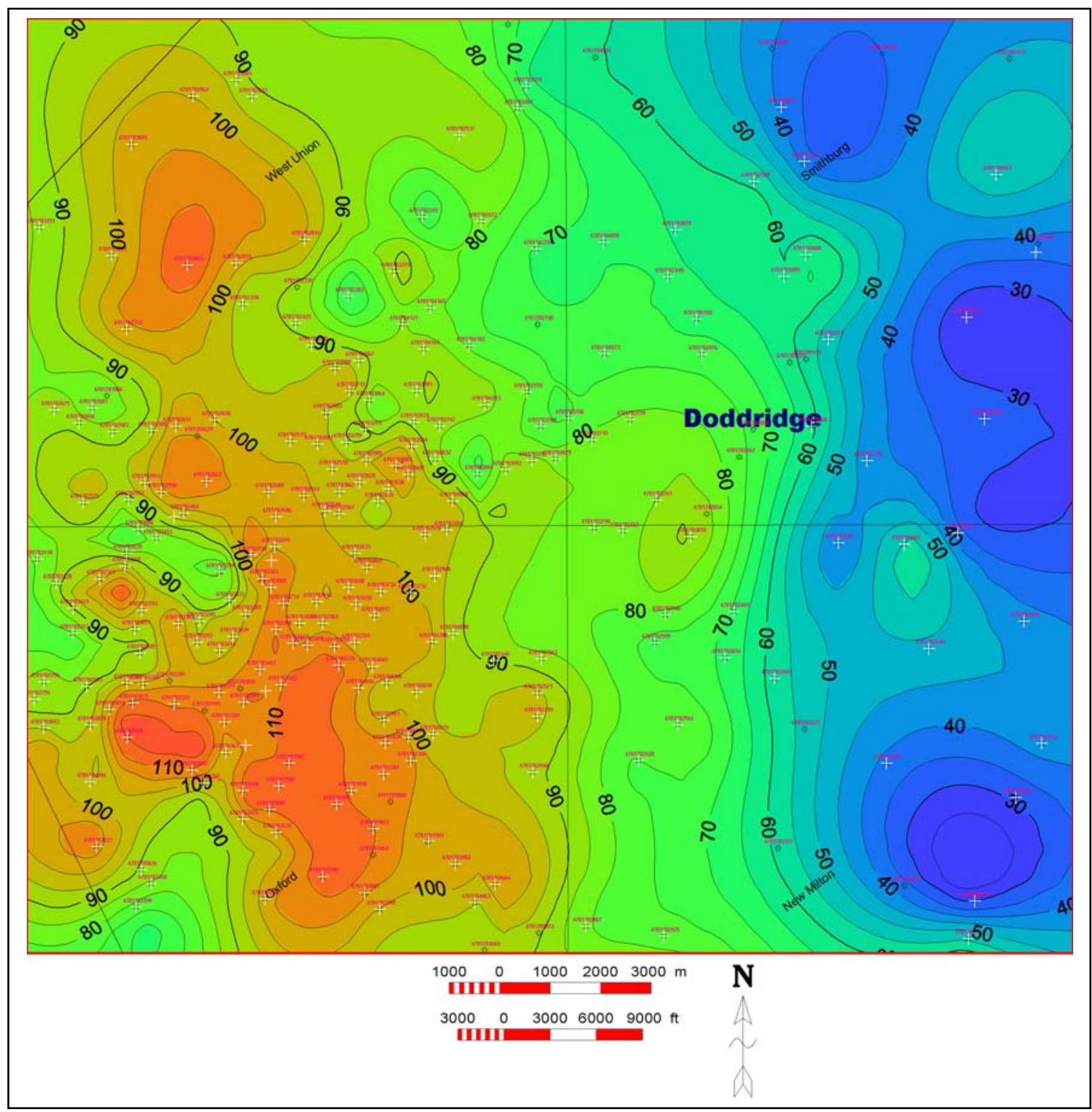

Figure 43: Net-pay map of siltstone with $6 \%$ or more porosity $(2.60 \mathrm{~g} / \mathrm{cc})$, using the Zone Manager application of Geographix. Contour interval equals 5 feet. The thickness ranges from less than 30 feet (blue) to over 120 feet (red). The white circle on this map shows the location of well \#4701701903. Arrow shows where siltstone was moved more towards the center of the study area. 


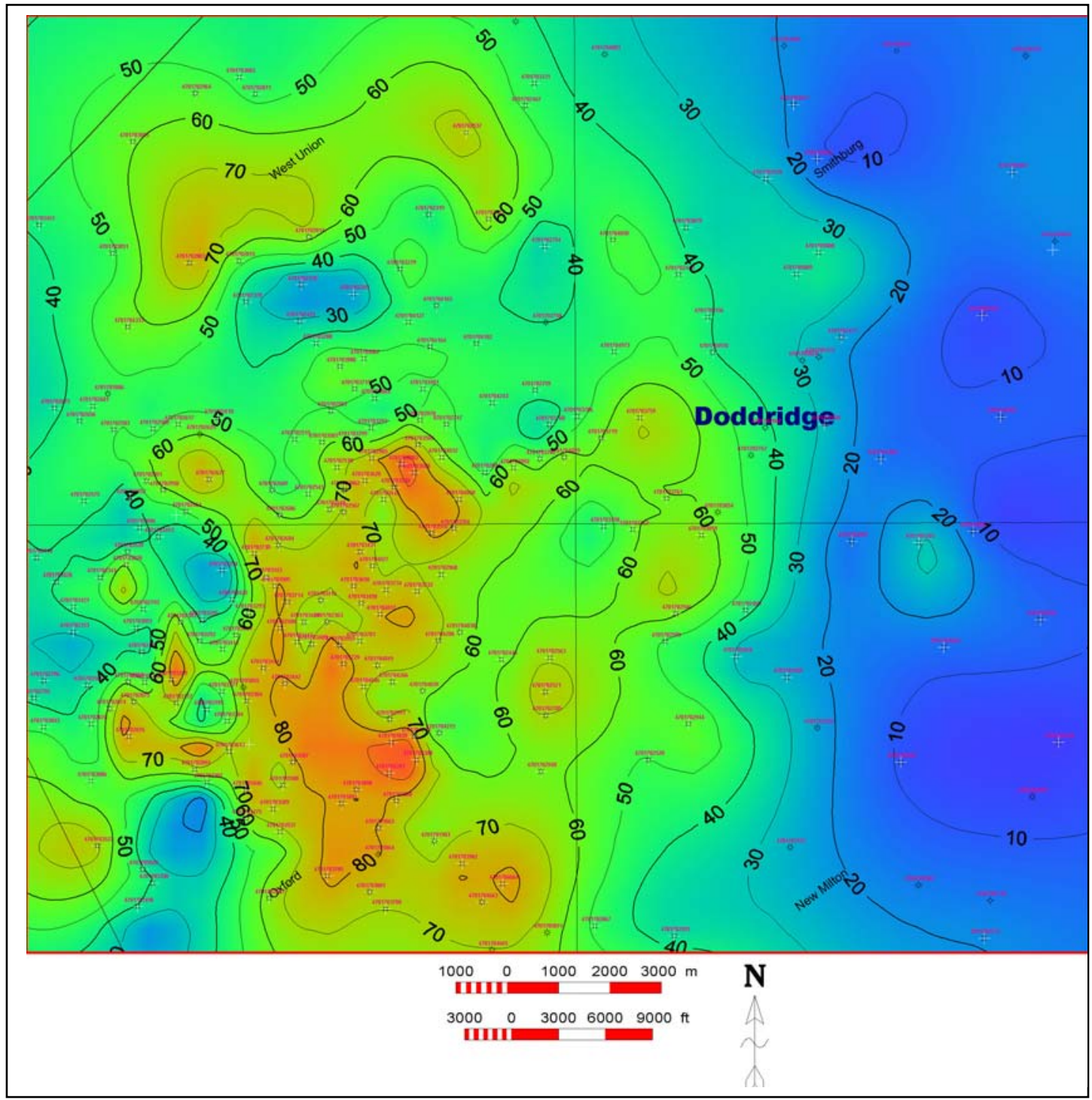

Figure 44: Net-pay map of siltstone with $8 \%$ or more porosity $(2.55 \mathrm{~g} / \mathrm{cc})$. Contour interval equals 10 feet. The thickness ranges from less than 10 feet (blue) to over 80 feet (red).

Analysis of the thin sections showed that most of the porosity within the Lower Weir is moldic pores (Figure 45). Moldic pores are a form of secondary porosity caused by the dissolution of chemically unstable grains after deposition. The major components of dissolution are often carbonates minerals, but silicate and sulfate minerals may also play a role (Schmidt and McDonald, 1979). Secondary pores are recognized in thin 
section as those with a diagnostic shape or texture that is consistent with the outlines of the precursor grains. The average size for moldic pores in the Lower Weir beds was measured in 14 of the 15 thin sections extending through the Lower Weir (Figure 46). Twenty-five pores were measured on each slide to obtain a representative mean pore size. Sizes range from 25 to 49 microns, which are classified as micropores by the scheme of Choquette and Pray (1970). The sample at 2194.3 feet had very little moldic porosity although this sample did contain a single large fracture. Similar fractures were also identified at 2209.3 feet (Figure 47). Fractures pores are identified as detachment planes within the rock (Schmidt and McDonald, 1979).

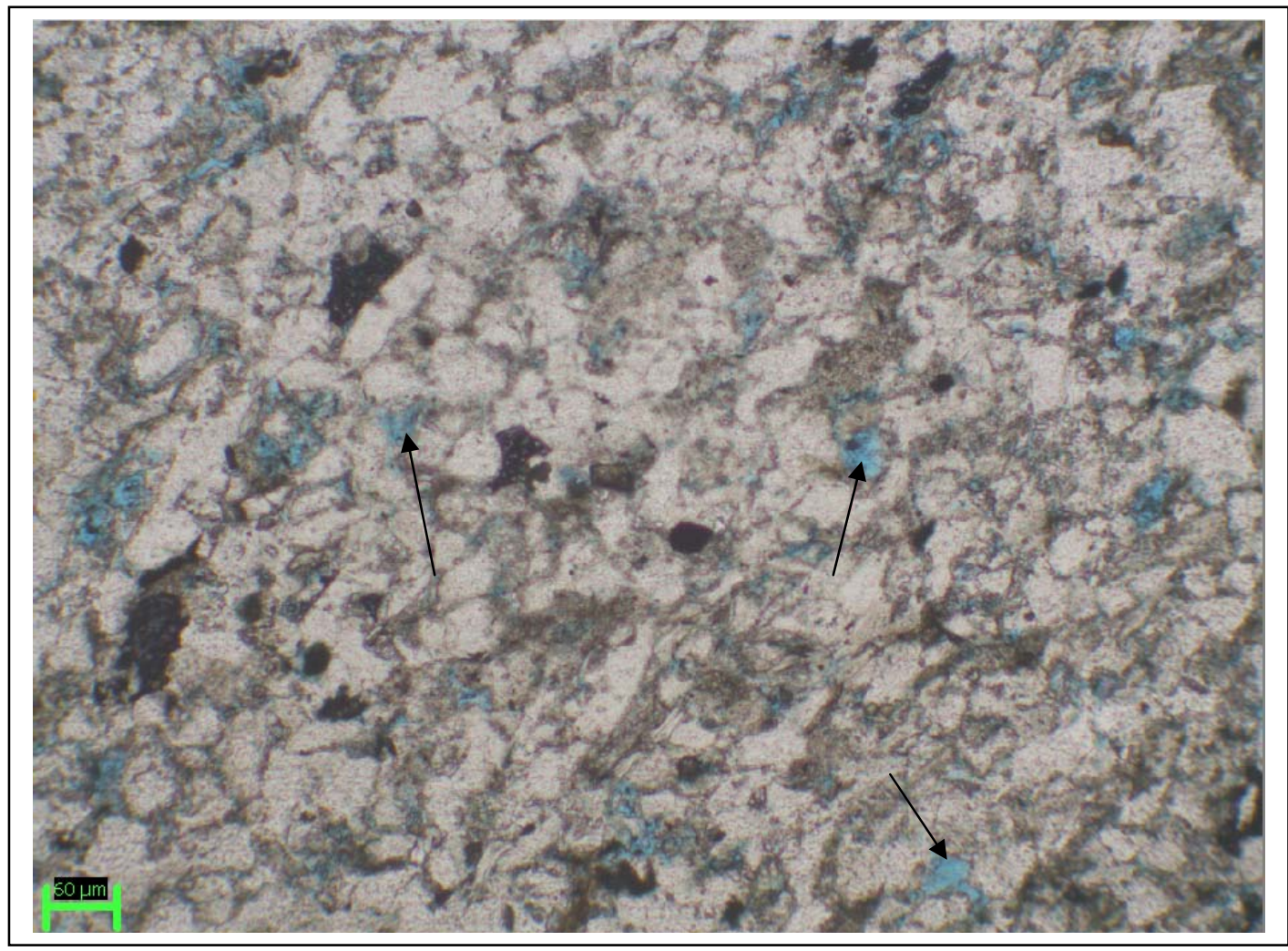

Figure 45: Photomicrograph of the Lower Weir sample at 2178.25 feet. The arrows point to the relatively large moldic pores. Scale is 60 micrometers. 
Figure 46: Pore size data from 15 Weir thin sections.

\begin{tabular}{|c|c|}
\hline $\begin{array}{c}\text { Depth } \\
\text { (feet) }\end{array}$ & $\begin{array}{c}\text { Mean } \\
(\mu)\end{array}$ \\
\hline 2159.2 & 43.4 \\
2166.3 & 33.5 \\
2178.3 & 40.7 \\
2187.5 & 35.9 \\
2190.3 & 35.7 \\
2194.3 & $\mathrm{NA}$ \\
2201.3 & 42.1 \\
2209.3 & 25.6 \\
2222.3 & 39.2 \\
2226.3 & 40.8 \\
2230.2 & 42.5 \\
2235.2 & 46.4 \\
2247.3 & 36.9 \\
2253.3 & 42.2 \\
2257.4 & 49.5 \\
\hline
\end{tabular}




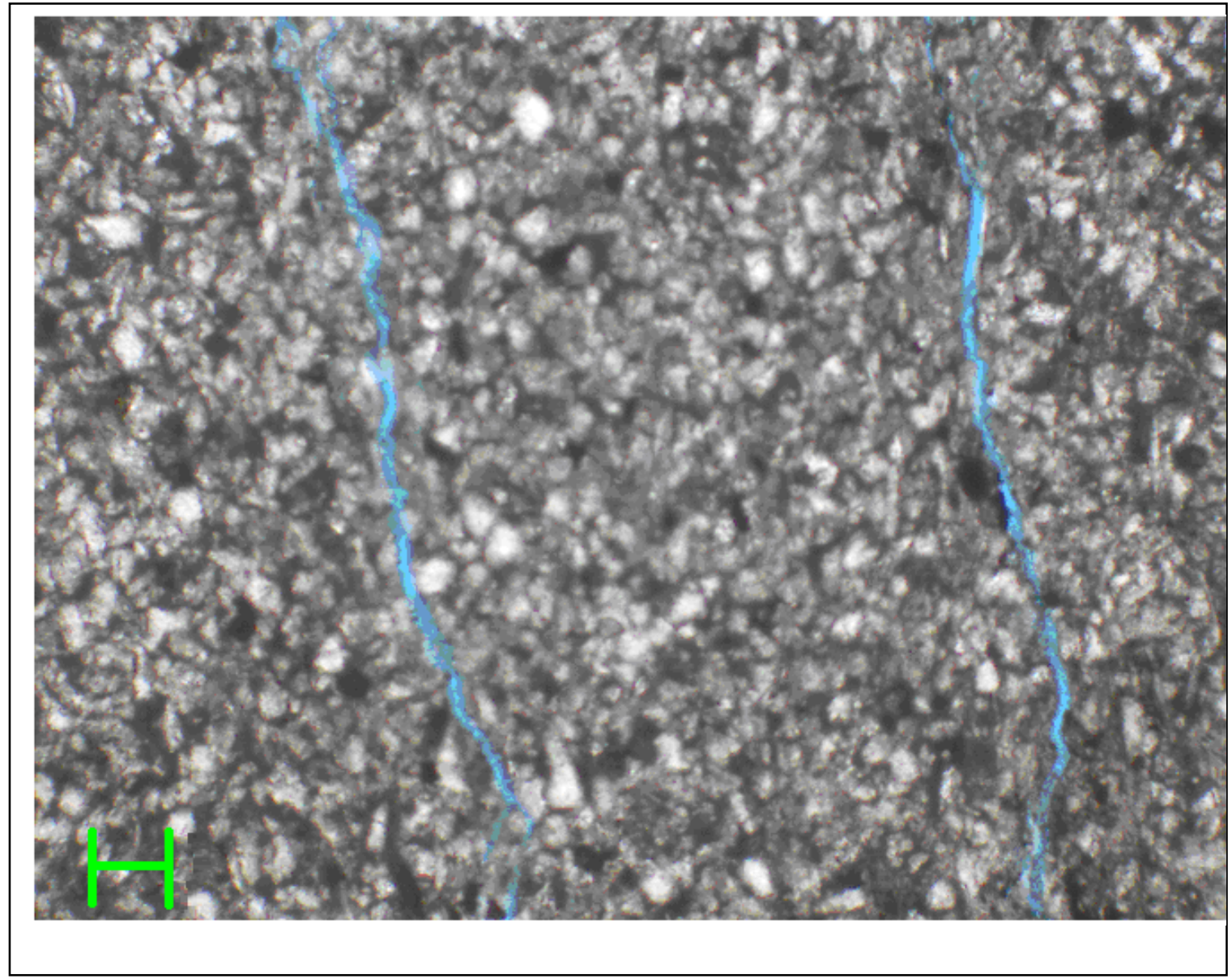

Figure 47: Photomicrograph of the Lower Weir at 2209.3 showing the linear microfractures. Scale is 60 micrometers.

Figure 48 shows the log plot for the Lower Weir beds and includes core porosity (COREPOR) and the average porosity recorded from the well log (PHIA). The figure also shows the permeability (PERMKBERG) of the overall unit. A plot of core porosity and permeability allows for a visual identification of the optimum zones for treatment (Figure 49). The optimum zones for stimulation must have both high porosity and permeability. The best zone for porosity is located at 2230 feet $(\Phi=10 \%)$, whereas the best permeability is located at 2160 feet $(\mathrm{k}=.085 \mathrm{md}$, excluding shale partings). Three zones (Figure 48) were selected in Figure 49 as optimum zones that contain both high porosity (greater than $7 \%$ ) and permeability (greater than $0.010 \mathrm{md}$ ). 


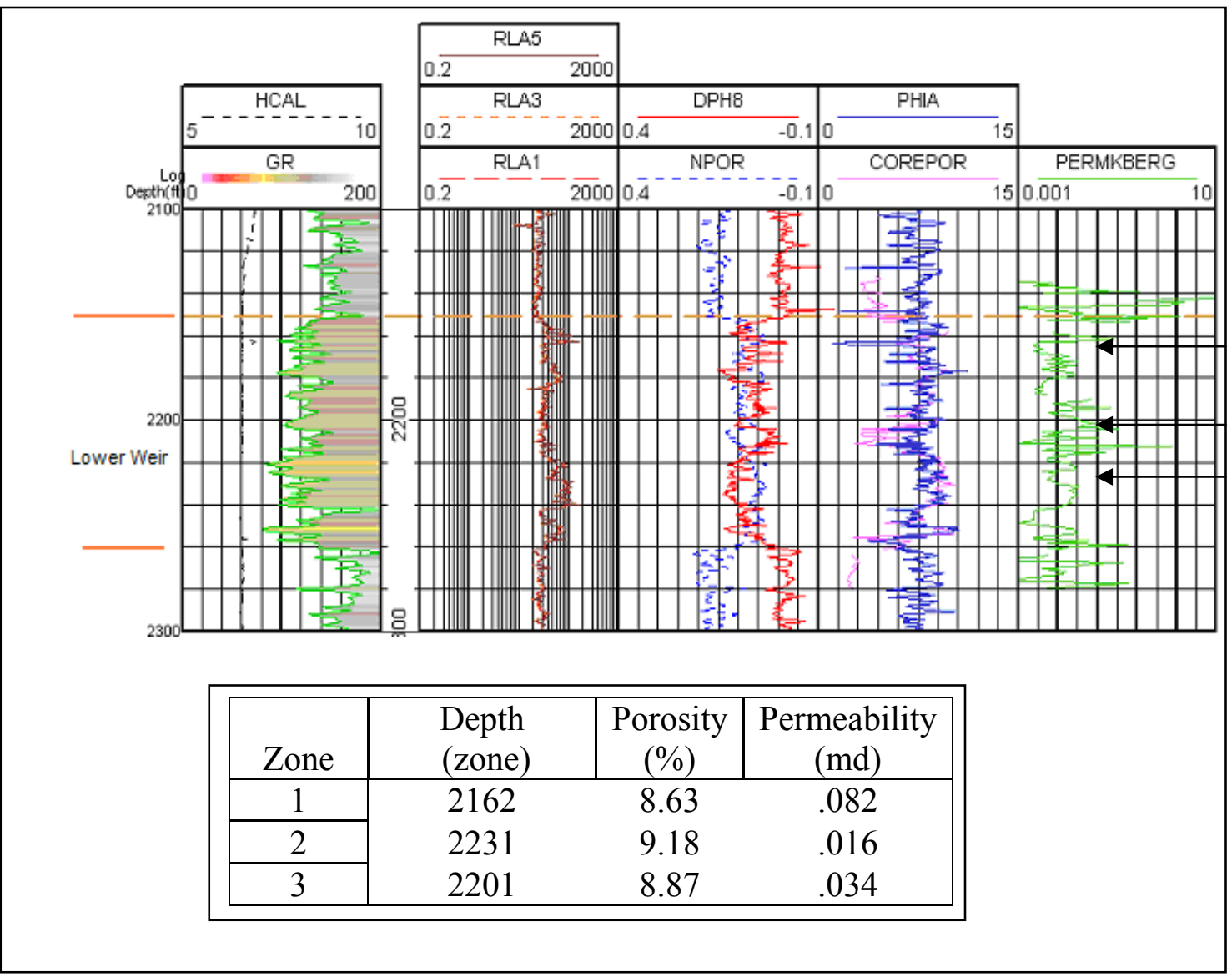

Figure 48: Log plot showing the relationship between the core porosity (COREPOR) and the average porosity recorded from the well log (PHIA) on second track from the right. The track on the right shows the permeability (PERMKBERG) of the overall unit. 

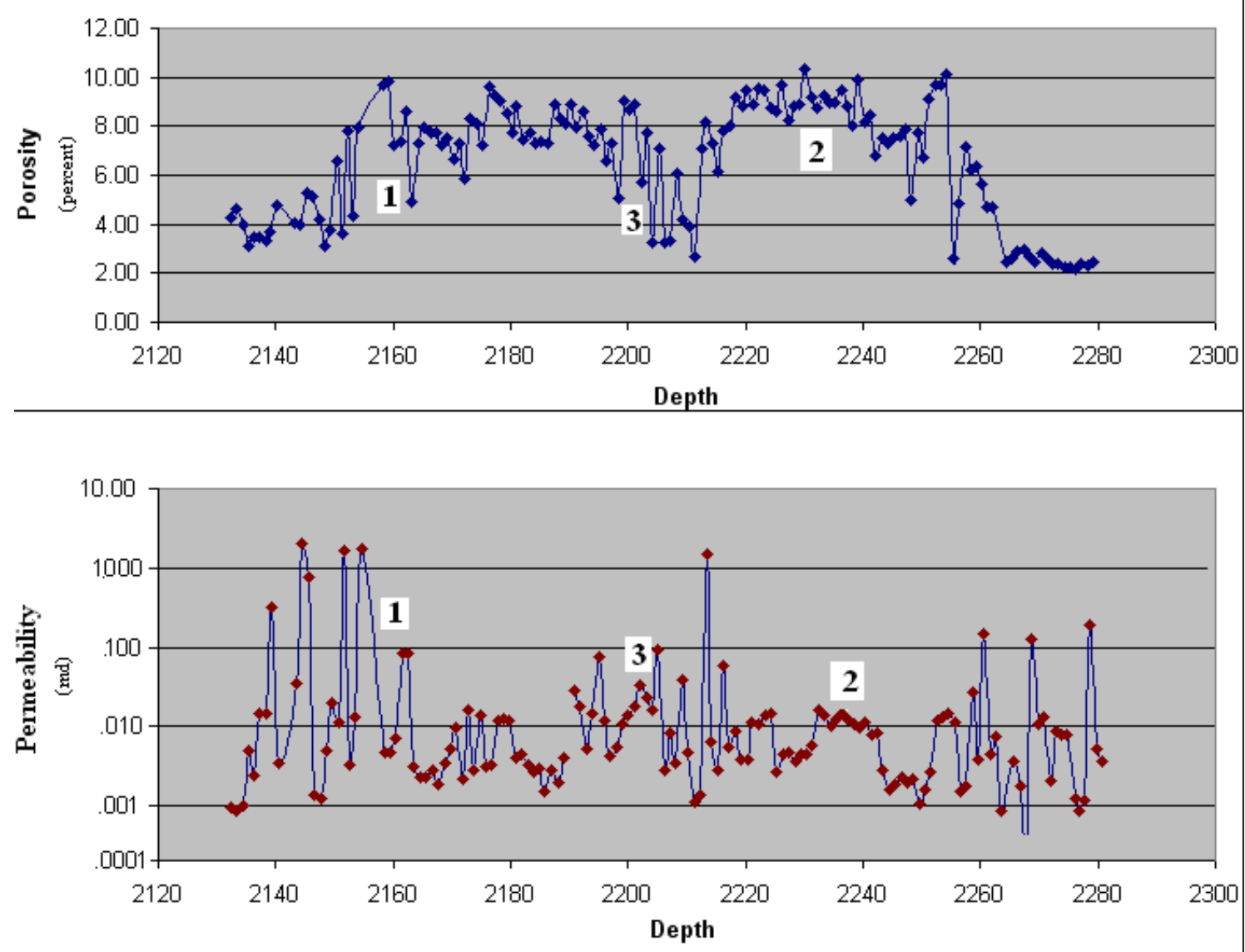

Figure 49: Plots of core porosity (top) and permeability (bottom) illustrate the three best zones for treating the Lower Weir. Using a 8\% cut off this figure shows that the greatest porosity is in the lower half of the Weir zone. Using a $6 \%$ cut off ideal porosity is seen throughout the Weir.

Water saturations values have been calculated from the Archie Equation for well \#4701705448 from 2150 to 2262 feet (Lower Weir beds) using the PfEFFER add-in model for Excel. Porosity and permeability data collected at quarter-foot intervals throughout this zone comprise the necessary values to calculate water saturation using Archie's equation. Once the values of water saturation have been calculated, they can be graphically represented using a Pickett Plot. The Pickett Plot is a logarithmic chart which graphs porosity versus resistivity and allows for a graphical representation of water 
saturation (Figure 50). The advantage of the Picket Plot is that similar water saturation values will plot on a straight line even if the porosity and resistivity values vary. This allows one to easily separate the formation into zones based on their calculated water saturation (or conversely gas saturation).

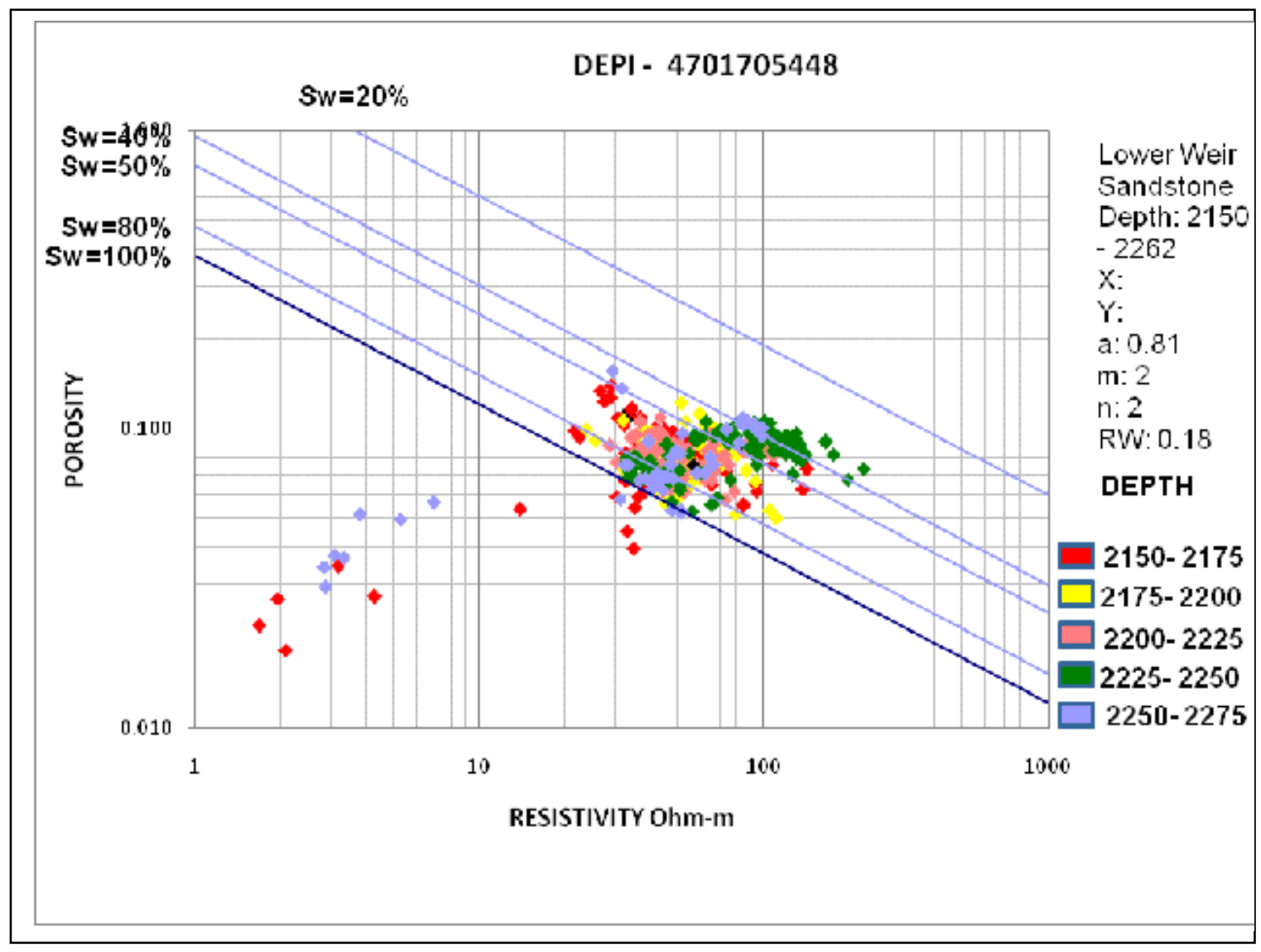

Figure 50: Pickett Plot for the Lower Weir beds in well \#4701705448.

The red and blue points which fall outside the main concentration of data (low resistivity and low porosity) represent the surrounding shales. The large cluster of points on this plot which falls in the range between $50 \%$ and $100 \%$ water saturation (red, pink, blue, and yellow) marks zones within the Lower Weir siltstone bed that would be uneconomical. The zone between 2225 feet and 2250 feet (green) has lower watersaturation values, and a higher resolution Pickett Plot can be generated for this portion of 
the data. This higher resolution plot allows for the zone of interest to be narrowed to a few feet. These data were seperated and replotted in Figure 51.

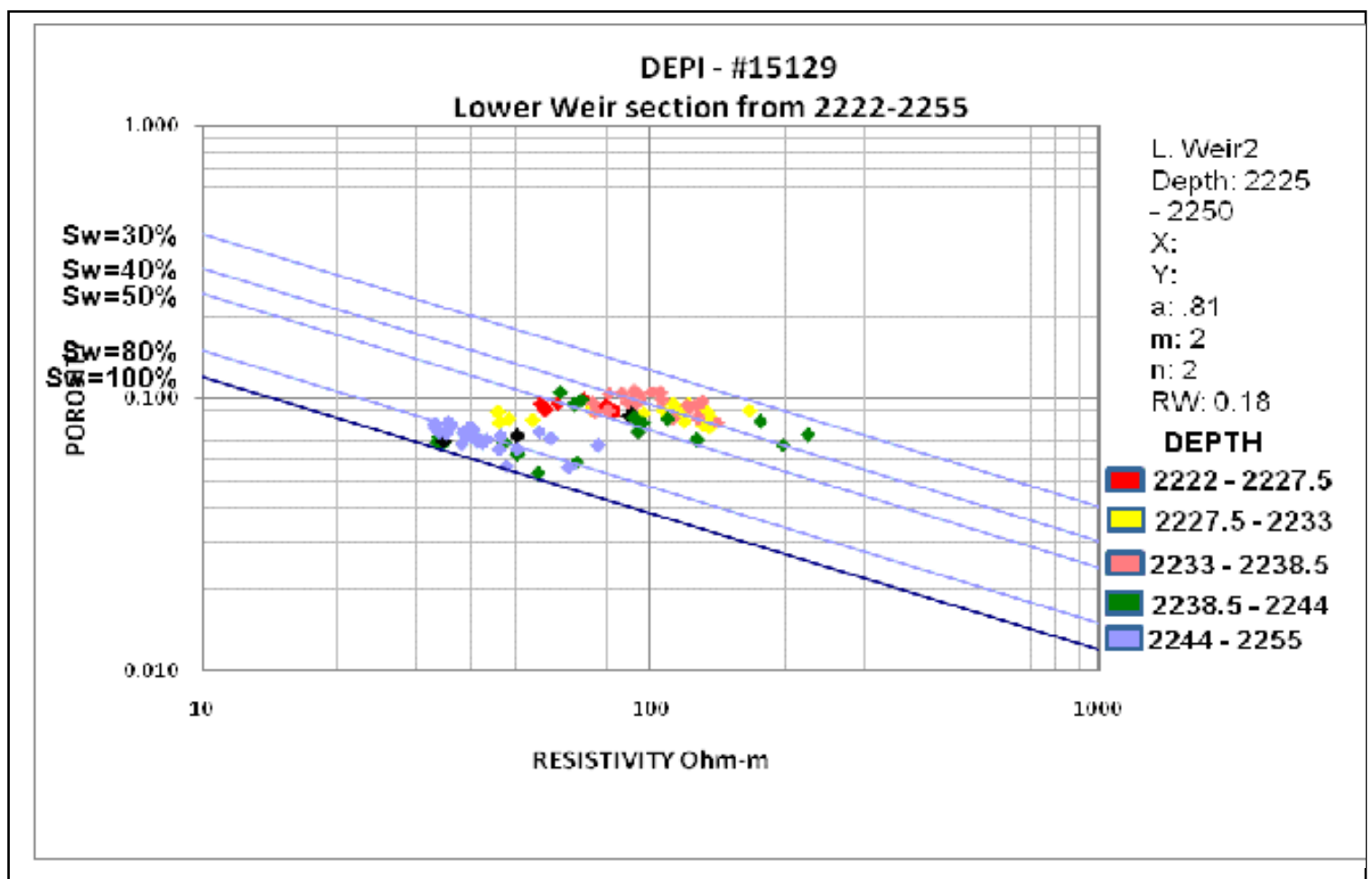

Figure 51: Pickett Plot for the specific zone from depths 2225 to 2250.

By isolating each portion of the Lower Weir, a narrow window can be identified for oil and gas exploration. The optimum zone is at 2233 to 2238.5 feet. The pink dots on the graph represent depths with a water saturation of $35-50 \%$, or conversely a gas saturation of $50-65 \%$. This zone also has the highest range of porosity values, between $8-10 \%$. Other portions of the Lower Weir beds have water-saturation values above $50 \%$. Those zones would produce some hydrocarbon; however, they would produce a larger quantity of water which would be cost ineffective. Identifying the zone with the lowest water saturation is important for every reservoir, but especially one in which the overall porosity and permeability of the unit are unusually low. As stated above, the Lower Weir beds are a fining-upward sequence, and the higher porosity values $(>8 \%)$ are found 
in the lower portions of this unit, and higher porosity zones have the highest permeability of the reservoir. The higher-porosity zones would also be subject to less clogging at pore-throats by dislodged clays, if the higher porosity values correlate to a larger size of the pore throats.

The Pickett Plot identified the Lower Weir at depths of 2233- 2238.5 feet as an optimum zone for treatment. The core porosity here exceeds $9 \%$ and the permeability is $0.010 \mathrm{md}$. This low value for permeability meets the National Energy Technology Laboratory definition of a tight sand and indicates the need for fracture stimulation to enhance production from this reservoir.

Structure

Identifying the location of anticlines and synclines is fundamental for oil and gas exploration and production in traditional reservoir formations of this basin. It is logical, therefore, to assume that finding the structural highs of the Lower Weir beds would aid in production from this unit. The regional shallow structural geology of Doddridge County is thought to be illustrated by the Mississippian Big Lime (Figure 52). Comparing the Big Lime structure map to that of the Lower Weir (Figure 53) shows only minor variation. This variation is caused by a major erosional unconformity and changes in thickness of the units which fall between the Big Lime and the Lower Weir. The subsurface stratigraphy of western Doddridge County is strongly marked by the Arches Fork anticline which trends at N45E through the northern half of the study area and N30E in the southern half of the study area. This anticline has long been a target for oil and gas 
production (Hennen, 1912). The structural low to the east is the Robinson syncline, and that to the west is the Burchfield syncline (Cardwell and Avary, 1982). 


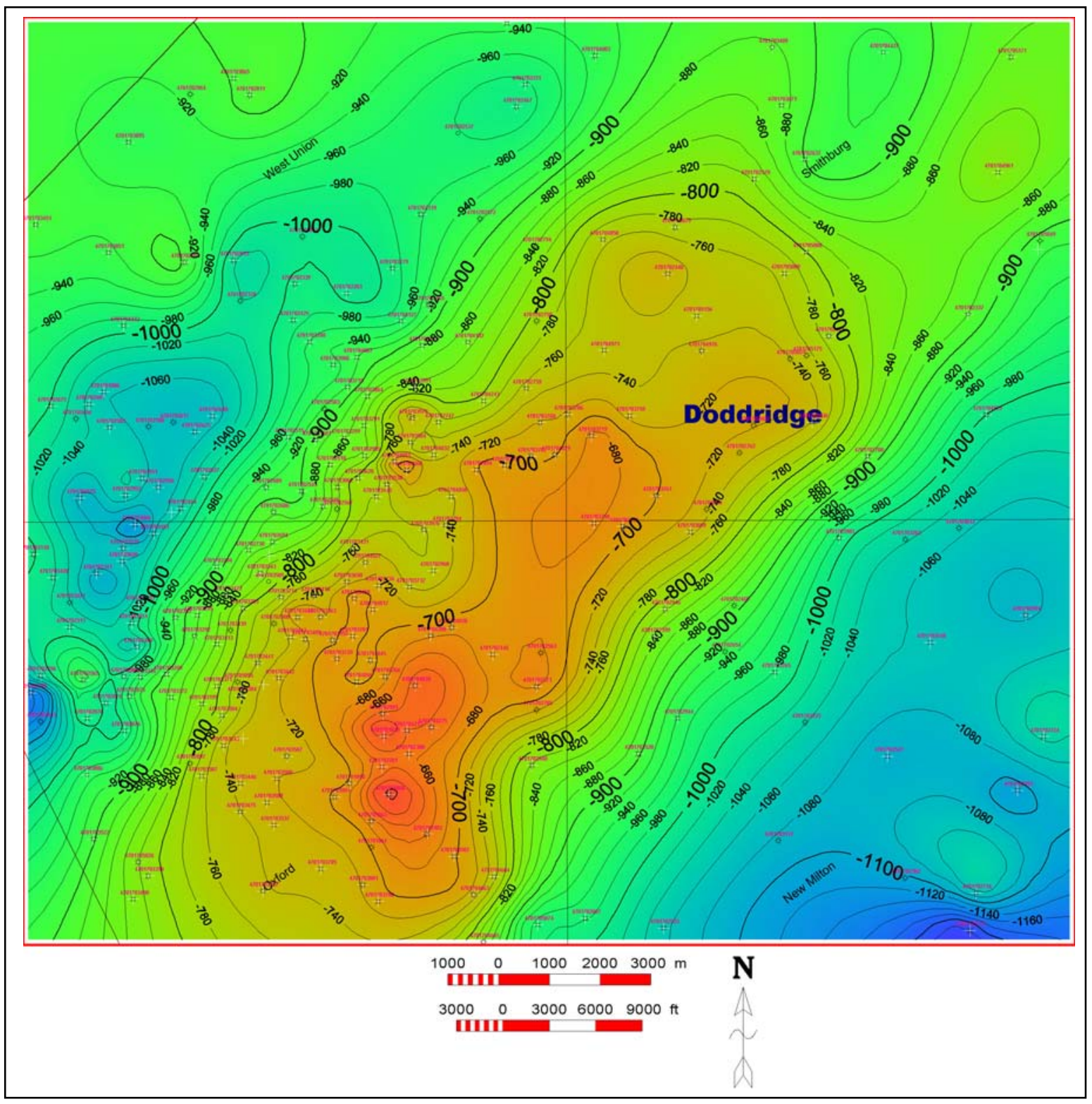

Figure 52: Structure map of the top of the Big Lime with a contour interval of 20 feet. The highest portion of this anticline is 620 feet below sea level. The adjacent synclines are structural lows with subsea depths greater than 1000 feet. 


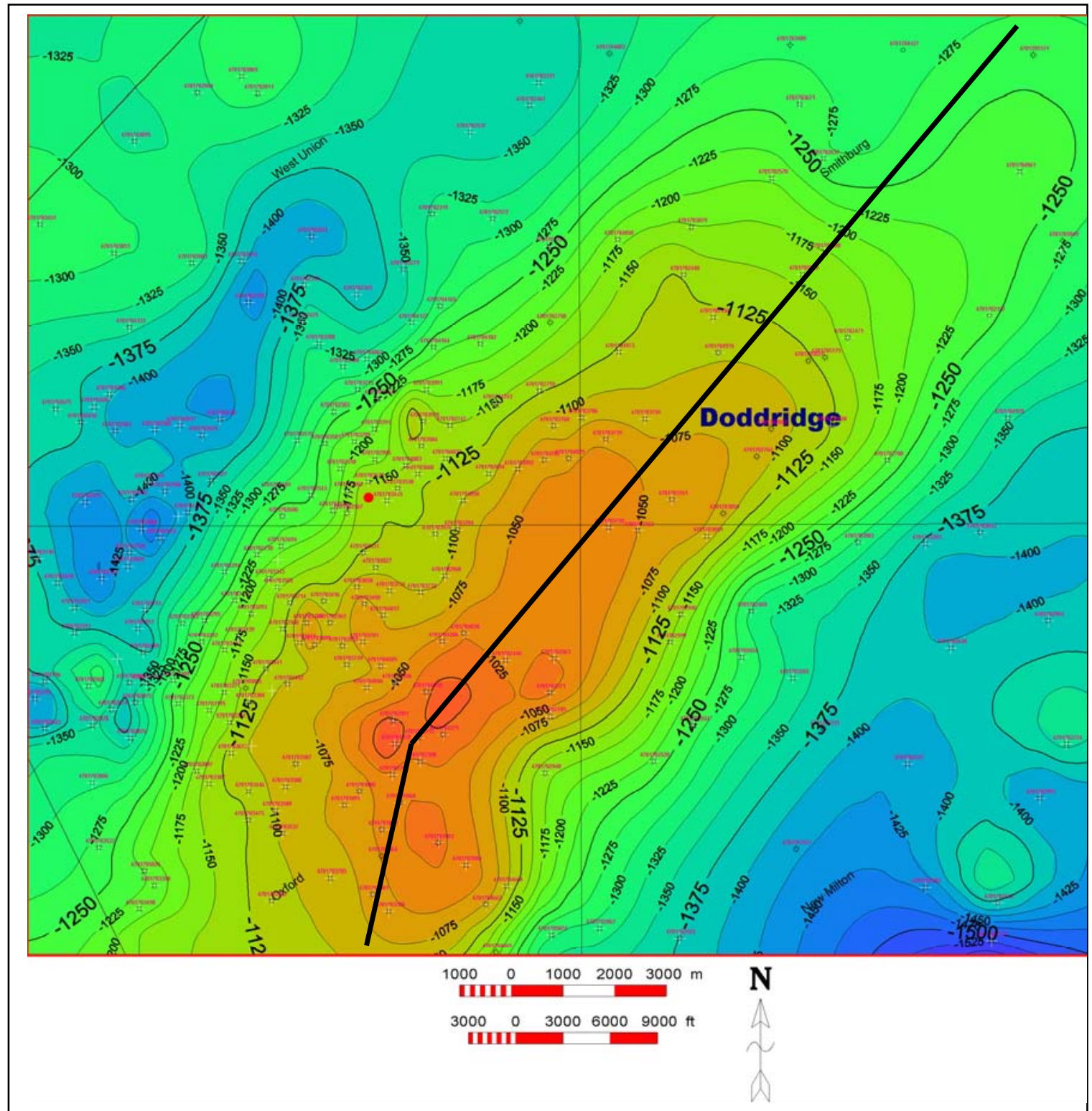

Figure 53: Structure map of the Lower Weir beds with a contour interval of 25 feet. This map also shows the approximate location of the Arches Fork anticline represented by black lines. The highest portion of this anticline is at 960 feet below sea level. The adjacent synclines are at subsea depths over 1400 feet. Open circles represent data points. The red circle indicates the cored well.

In well \#4701705448 the structural dip of the Lower Weir beds is shallow, between 2 and 3 degrees with consistent azimuth WNW (Figure 54). The dip of the formation was recorded at one foot intervals across the Lower Weir beds and recorded on 
the FMI as a tadpole plot. This dip matches the structure map (Figure 53), indicating that the Lower Weir beds at this location are on the west side of the Arches Fork anticline.

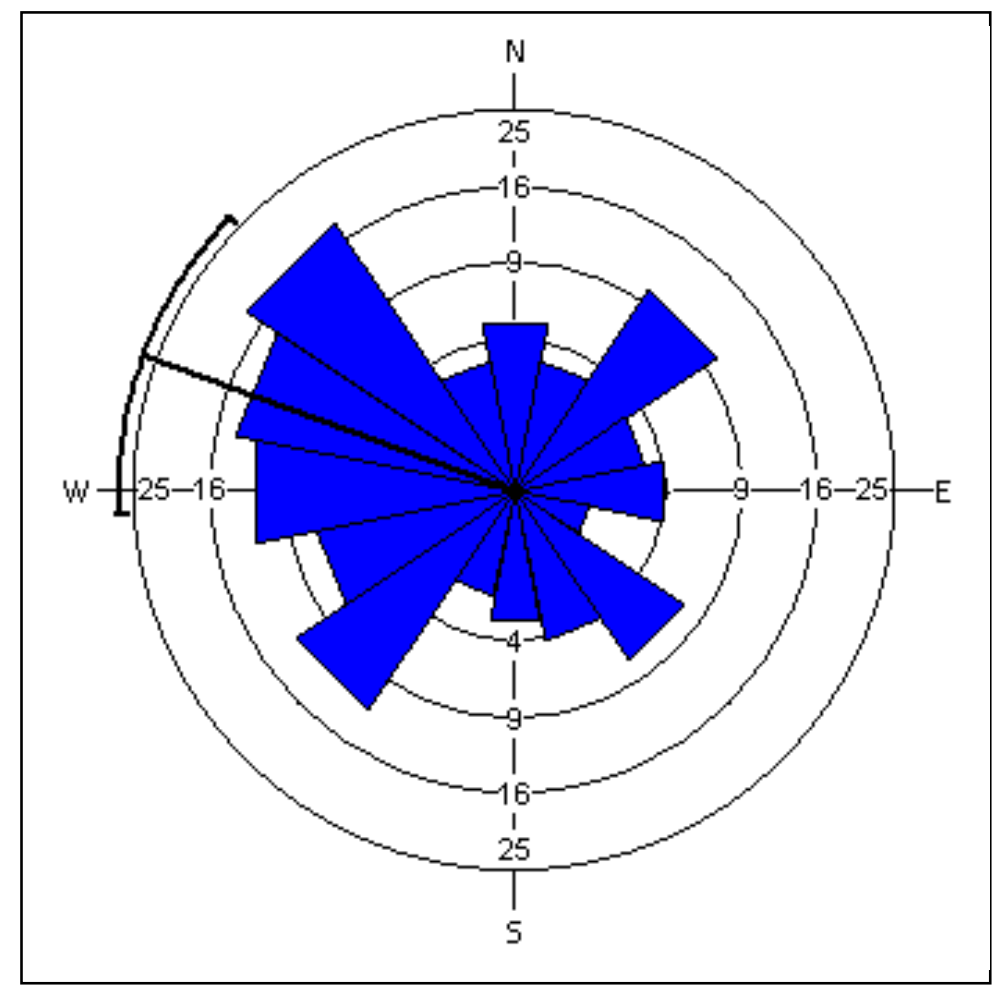

Figure 54: Rose Diagram of the structural dip direction in the Lower Weir beds as recorded on a dipmeter on the FMI log from well \#4701705448. Mean vector of $290^{\circ}$. Data point was collected at 1 foot intervals through the Lower Weir beds.

There were only two fractures identified on the FMI log of the Lower Weir beds. The location of a possible partial fracture was identified on FMI log at 2256.5, with a N9E strike and dipping 73 degrees to the SE. A partial fracture is any fracture that was at one time fully open but has been filled at least partially with cement and has therefore a lower effective permeability. This fracture was not observed in the core itself; instead a small shale parting is present at this depth and deformed by soft-sediment deformation. A partial fracture was positively identified at 2232.75, with a strike of N8E and dipping 
at 74 degrees ESE. These fractures are orientated parallel to the fold of the Arches Fork anticline and identified as strike joints. Their formation is probably associated with extension of the Lower Weir during growth of the Arches Fork anticline. These fractures appear at the base of the Lower Weir beds and would aid in the flow of gas through the unit. Moreover, the partial fracture occurs at the top of the zone indicated on the Pickett plot (depths 2233-2238.5 feet) to be optimum in terms of porosity and water saturation.

\section{Potential Reserves}

In order to determine the financial feasibility of production from the Weir zone, some simplifying assumptions must be made. Assuming the cost of gas at the well head to be $\$ 5.00$ per Mcfg along with the initial additional drilling cost of $\$ 15,000$ to reach the base of the Lower Weir a timetable can be set up to determine when a well producing from the Weir zone would become profitable.

The difficulty is that the Weir gas in this area is typically commingled with gas from other reservoirs. Production data is available for only one well, \#4701701903. Using well \#4701701903 to be representative of production through study area from the Lower Weir zone provides us with an estimate for future production from this unit. Well \#4701701903 produces only from the Lower Weir sandstone beds at an initial rate of $25 \mathrm{Mcf} / \mathrm{d}$ after 27 years of production with an estimated recovery of 160,000 Mcf (Figure 55). 


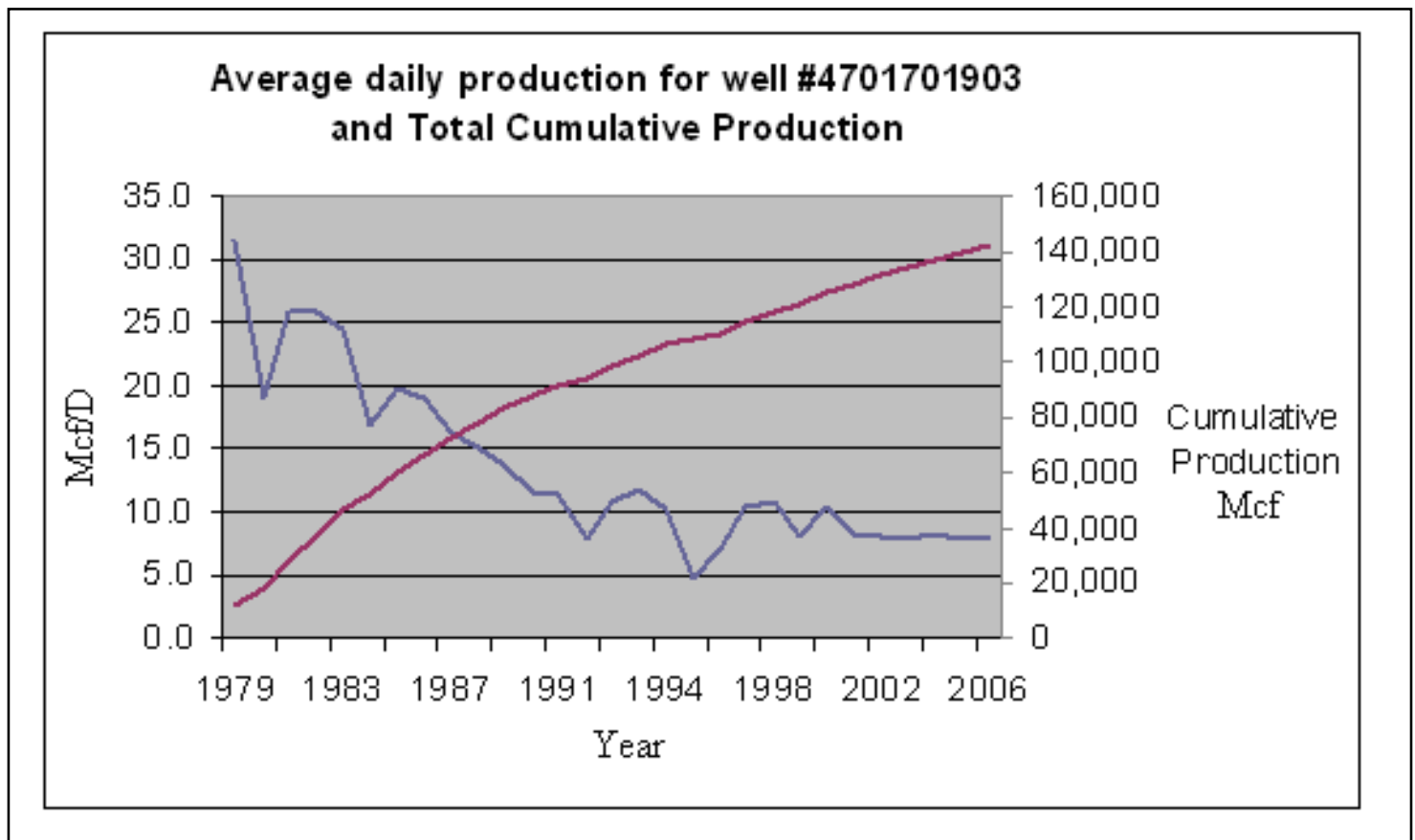

Figure 55: Average daily production and total cumulative production for well \#4701701903. Red line is the cumulative productive curve. The blue line indicates average $\mathrm{Mcf} / \mathrm{D}$.

Production from well \#4701701903 would have recovered the $\$ 15,000$ cost within 100 days of production. By combining the production data for this well with the siltstone percent map of the Lower Weir, (Figure 46) an estimate can be made for the amount of time required for future Weir wells to become economical. Well \#4701701903 falls within the map area of 95\% siltstone in the Lower Weir. Figure 56 was generated by extending the time required for a well to produce enough gas to pay for the extra drilling cost required for Weir production. These values in days were arrived at by adjusting probable production values from wells within the study area based on the production from \#4701701903 and the percent of siltstone within each well. 


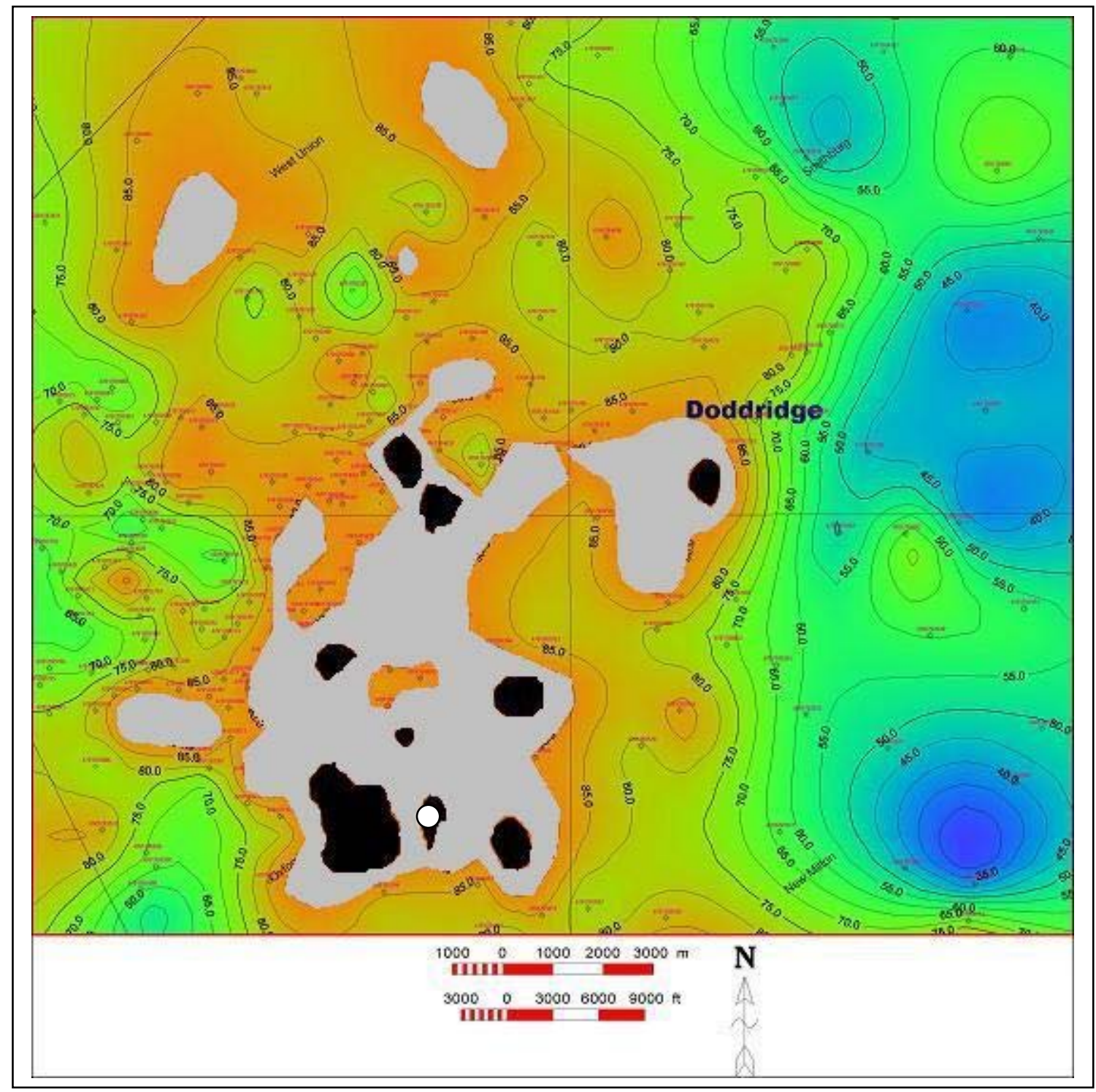

Figure 56: Time map overlaying percent siltstone map. This illustrates the areas where the Lower Weir zone is expected to return a profit. Black areas represent those areas that will likely pay out in less than 100 days. Gray areas represent those areas that are likely to become profitable within 120 days. The white circle represents the approximate position of well \#4701701903. 


\section{CONCLUSIONS}

The Lower Weir siltstone in Doddridge County, West Virginia is an unconventional reservoir comprised of siltstone with a mineral composition of primarily quartz, illite, and possibly potassium feldspar. The siltstone beds found within the Lower Weir pinchout laterally within a few miles, this limits ability to correlate the unit. The three lithologies which are recognized with this unit are coarse siltstone, fine siltstone and clay. These units were deposited on the outer shelf under the influence of shoaling internal waves. The productive areas within Doddridge County are zones of anomalously thick coarse siltstone that trend north - south and are up to 110 feet thick and four miles wide. Porosity within the Lower Weir siltstone is controlled primarily by moldic micropores along with minor microfractures. The microfractures within the siltstone also aid in the permeability of this unit. Three zones were identified with porosity greater than $7 \%$ permeability greater than $0.01 \mathrm{md}$. These zones also contained a minimum water saturation of between $35-50 \%$ and are considered to be the best reservoirs. Reservoir quality is likely to increase along the Arches Fork anticline where the formation of strike joints has likely increased. The areas identified within the study area where expected production from the Lower Weir beds should exceed drilling and completion cost within 100-120 days should be the primary focus of future investigation. These areas coinciding with natural structural advantage of the Arches Fork anticline should be the focus of early exploration. 


\section{REFERENCES}

Bjerstedt, Thomas W., 1986, Stratigraphy and deltaic depositional systems of the Price Formation (Upper Devonian-Lower Mississippian) in West Virginia: Ph.D. thesis, West Virginia University, Morgantown, WV, 298 p.

Bjerstedt, T. W. and Kammer, T. W., 1988, Genetic stratigraphy and depositional systems of the Upper Devonian-Lower Mississippian Price-Rockwell deltaic complex in the Central Appalachians, U.S.A.: Sedimentary Geology, v. 54, p. 265301.

Boswell, Ray, 1985, Stratigraphy and sedimentation of the Acadian Clastic Wedge in Northern West Virginia: Master's thesis, West Virginia University, Morgantown, WV, $179 \mathrm{p}$.

Boswell, Ray M., 1988, Basin Analysis of the Acadian Clastic Wedge in Northern West Virginia and Adjacent Areas: Ph.D. thesis, West Virginia University, Morgantown, WV, $351 \mathrm{p}$.

Boswell, R. M. and Jewell, G. A., 1988, Atlas of Upper Devonian/Lower Mississippian sandstones in the subsurface of West Virginia: West Virginia Geological and Economic Survey, Circular C-43, 144 p.

Cardwell, D. H. and Avary, K. L., 1982, Oil and gas fields of West Virginia, Morgantown, West Virginia, Geological and Economic Survey, v.MRS-7B

Carr, Tim, 2008, Personal communication.

Choquette, P. W. and Pray, L. C., 1970, Geologic Nomenclature and Classification of Porosity in Sedimentary Carbonates: Bulletin of the American Association of Petroleum Geologists, v. 54, p. 207-250.

Doveton, John H., 1994, Geological Log Interpretation: SEPM Short Course Notes, No. 29, 169 p.

Ettensohn, Frank R., 2005, Cyclic Development of Sedimentary Basins; the Sedimentary Record of Foreland-Basin, Tectophase Cycles: Examples from the Appalachian Basin, USA: Cyclic Development of Sedimentary Basins, Mabesoone, J.M. Neumann, V.H. (eds.), Elsevier Science, v.57 p. 139-172 
Harper, J. A. and Laughrey, C. D., 1987, Geology of the oil and gas fields of southwestern Pennsylvania: Mineral Resources Report, Pennsylvania Geological Survey, No. 87, 166 p.

Harper, J. A. and Laughrey, C. D., 1989, Upper Devonian and Lower Mississippian stratigraphy and depositional systems; Geology in the Laurel Highlands of southwestern Pennsylvania: Guidebook for the Annual Field Conference of Pennsylvania Geologists, Pennsylvania Geological Survey, v. 54, p. 35-62.

Hennen, R. V., 1912, Doddridge and Harrison Counties: West Virginia Geological Survey, Morgantown W.V., 712 p.

Kansas Geological Survey, 1998, PfEFFER Version 2.0. Petrofacies Evaluation of Formations for Engineering Reservoirs,

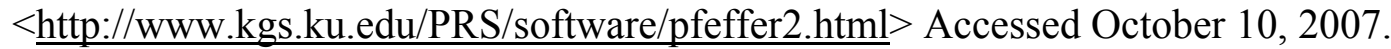

Matchen, David L., 1992, Sequence Stratigraphy of the Lower Mississippian Clastic Wedge in West Virginia and Kentucky: Master's thesis, West Virginia University, Morgantown, WV, $177 \mathrm{p}$.

Matchen, D. L. and Kammer, T. W., 1994, Sequence stratigraphy of the Lower Mississippian Price and Borden formations in southern West Virginia and eastern Kentucky: Southeastern Geology, v. 34, p. 25-41.

Matchen, D. L., and Vargo, A. G. 1996, Play Mws; Lower Mississippian Weir sandstones; Roen, John B; Walker, Brian J. (eds.):The atlas of major Appalachian gas plays, West Virginia Geological and Economic Survey, Morgantown, WV, v.25 p.46-50.

McDaniel, Bret A., 2006, Subsurface Stratigraphy and Depositional Controls on Late Devonian Early Mississippian Sediments in Southwestern Pennsylvania, Master's thesis, West Virginia University, Morgantown, WV, 90 p.

National Energy Technology Laboratory, 2007, Exploration \& Production Technologies; Natural Gas Production from Tight Sand Accumulations, $<$ http://www.netl.doe.gov/technologies/oilgas/EP Technologies/ExplorationTechnologies/TightGas/Tight_Gas.html> Accessed December 15, 2007.

Pratson, Lincoln F. et al, 2007, Seascape Evolution on Clastic Continental Shelves and Slopes; Nittrouer, C.A. et al, Continental Margin Sedimentation From Sediment Transport to Sequence Stratigraphy, Malden, MA, Blackwell Publishing, 339-380 p. 
Prothero, Donald R., 1998, Bringing Fossils to Life: An Introduction to Paleobiology: Boston, MA, McGraw-Hill, 512 p.

Reading, Harold G., 1996, Sedimentary Environments: Processes, Facies and Stratigraphy, Third Edition: Reading, Harold G. Shallow Clastic Seas; Malden, MA, Blackwell Science, 232-277 p.

Sager, Melissa L., 2007, Petrologic Study of the Murrysville Sandstone in Southwestern Pennsylvania: Master's Thesis, West Virginia University, Morgantown, WV, 90 p.

Schlumberger, 2002, FMI Borehole geology, geomechanics and 3D reservoir modeling, Product Brochure

Schwartz, Bryan C., 2006, Fracture Pattern Characterization of the Tensleep Formation, Teapot Dome, Wyoming, Master's Thesis, West Virginia University, Morgantown, WV, $148 \mathrm{p}$.

Schmidt, V. and McDonald, D. A., 1979, Texture and Recognition of Secondary Porosity in Sandstones, Aspects of Diagensis, Scholle, P. A. and Schluger, P. R.: SEPM, No. 26, p. 209-225.

Selley, Richard C., 1998, Elements of Petroleum Geology, Second Edition: San Diego, C.A., Academic Press, 463 p.

Sommerfield, C.K. et al, 2007, Oceanic dispersal and accumulation of river sediment; Nittrouer, C.A. et al, Continental Margin Sedimentation From Sediment Transport to Sequence Stratigraphy, Malden, MA, Blackwell Publishing, 157-212 p.

Zou, X., 1993, Sequence Stratigraphy of Lower Mississippi in Western West Virginia; Correlation, Depositional Environments, Controls on Sedimentation and Related Reservoir Heterogeneities: Ph.D. thesis, West Virginia University, Morgantown, WV, $414 \mathrm{p}$. 